


Läpinäkyvä viestintä 


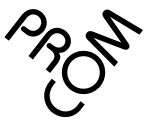

Päätoimittaja:

Vilma Luoma-aho, professori, Jyväskylän yliopisto

Toimituskunta:

Erkki Karvonen, professori, Oulun yliopisto

Leena Louhiala-Salminen, professori, Aalto-yliopisto

Elina Melgin, toimitusjohtaja, FT, ProCom - Viestinnän ammattilaiset ry

Hannu Nieminen, professori, Helsingin yliopisto

Tuula-Riitta Välikoski, professori, Tampereen yliopisto

Tuotanto:

Minna-Liisa Nurmilaakso, asiantuntija, ProCom

Taitto:

Virpi Vihervuori, Baasis Design

Jakelu:

Julkaisu on maksuton ProComin jäsenille. Jakelu tapahtuu tilauspohjaisesti. Kirjaa toimitetaan laajasti myös oppilaitoksiin käytettäväksi viestintäopintojen oheismateriaalina.

Osa artikkeleista jaetaan sähköisenä www.viestijat.fi -sivustolla.

Kirjaa voi myös tilata ProComista hintaan 25 euroa sisältäen postituskulut.

Kustantaja:

ProCom - Viestinnän ammattilaiset ry,

Kalevankatu 30, 7. krs, 00100 Helsinki

Puh. (09) 1357775

Koko ja paperi:

A5, 14,85 cm x $21 \mathrm{~cm}$

Munken Polar

ISSN 1799-3857

Paino:

Libris, Helsinki 2015
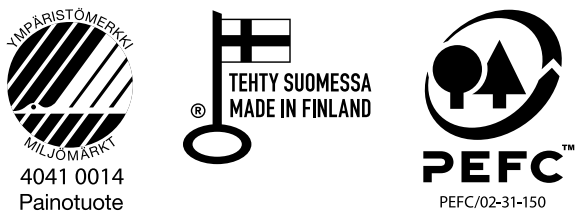

Painotuote

PEFC/02-31-150 
PROCOMMA ACADEMIC 2015

\section{Läpinäkyvä viestintä}


sis.

ESIPUHE

8

LÄPINÄKYVÄÄ?................................... 10

Vilma Luoma-aho

MAKSETTUJEN SISÄLTÖJEN

MEDIANÄKYVYYS 20

Kimmo Taiminen

VOIKO AVOIMUUDELLA LISÄTÄ

ORGANISAATION INNOVATIIVISUUTTA?

Petro Poutanen

VOIKO VAIKUTTAJAVIESTINNÄLLÄ LISÄTÄ YLEISTÄ HYVÄKSYNTÄÄ?

TAPAUS GUGGENHEIM HELSINKI ...44

Elina Melgin

SIJOITTAJIEN HARHAUTTAMISTA VAI STRATEGISTA EPÄMÄÄRÄISYYTTÄ?

Minea Hara 60

BIG DATA JA MEDIASUHTEET.

MITEN SUURET DATA-AINEISTOT MULLISTAVAT TAAS KAIKEN?

Turo Uskali

INFORMAATION ASEELLISTAMINEN JA TAISTELU IDENTITEETISTÄ 94 Aki-Mauri Huhtinen 
PROCOM MA ACADEMIC 2015

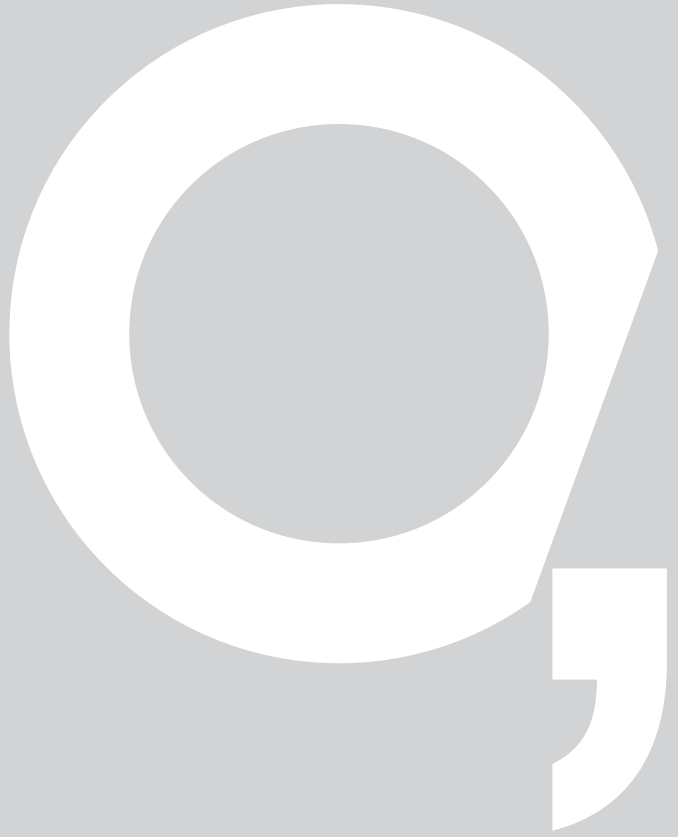




\section{O, $/ 10$}

\section{Tervetuloa \\ PROCOMMA ACADEMICIN \\ 2. numeroon, joka kysyy:}

\section{ONKO VIESTINTÄMME LÄPINÄKYVÄÄ?}

Kun sisällöntuotannosta on tullut viestinnän kuumin tehtävä, poliitikot siirtyvät viestintätoimistoihin töihin ja verkkoympäristössä taustakytköksien havaitseminen helpottuu, on selvää, että avoimuus ja läpinäkyvyys ovat nousemassa viestinnän keskiöön. Brändättyjen mediasisältöjen ja freelance-toimittajatyön yleistyessä on jopa ehdotettu, että "läpinäkyvyys on uusi objektiivisuus", sillä kenenkään ei oleteta enää olevan täysin puolueeton. Läpinäkyvyydellä leikittäessä leikitään kuitenkin aina luottamuksella, ja ilman luottamusta viestintä ei kanna. Viestinnän ammattilaisista on tulossa organisaatioiden läpinäkyvyyslähettiläitä.

ProComma Academic 2 avaa tutkijoiden näkökulmasta läpinäkyvyyden positiivista ja negatiivista puolta. Kirja lähestyy ajankohtaisia viestinnän teemoja dataviestinnästä ja brändätyistä sisällöistä sijoittajaviestintään, innovatiivisuuteen ja lupaan olla olemassa. Kirjoittajiksi on poimittu Suomen huippuasiantuntijoita eri teemoista, ja esitelty tieto on ProComma Academicin hengen mukaan läpinäkyvää ja tutkittua.

Johdannossa avaan, miten kaikki organisaation harjoittama avoimuus ja läpinäkyvyys ei välttämättä ole sitä sidosryhmien mielestä. Lisäksi läpinäkyvyysviestintä on aina avoin kutsu sidosryhmille arvioida entistä tarkemmin organisaation toimintaa, hyvässä ja pahassa. Viestinnän ammattilaisten tehtäväksi nouseekin läpinäkyvyysodotusten monitorointi ja rakentaminen, sillä sidosryhmät ovat valmiita osallistumaan yhä enemmän organisaatioiden toimintaan. Kimmo Taiminen esittelee tästä yleisöjen suurempaan osallistumiseen tähtäävästä toiminnasta yhden uuden muodon: maksetun sisällöntuotannon. Kun brändi ja media tekevät yhteistyötä, toimitaan alustoilla, joihin traditionaalisesti on ollut pääsy vain journalisteilla. Läpinäkyvyys nousee keskiöön 


\section{O, / 11}

myös journalismin muuttuessa datajournalismiksi, jolloin Turo Uskalin mukaan mediasuhteet muuttuvat tiedottamisesta suurien aineistojen avaamiseksi.

Kun organisaatiot suunnittelevat viestintäänsä, herää kysymys, voiko läpinäkyvyyden vastakohta, epämääräisyys, olla harkittu viestintästrategia. Minea Hara esittelee strategista epämääräisyyttä sekä ideatasolla että käytännössä Talvivaaran tiedottamisen kautta. Näyttäisi siltä, että myös liian optimistinen tiedottaminen voi olla strategisesti epämääräistä ja siksi läpinäkyvyyden vastaista. Yleisen mielipiteen ohjailu on keskiössä myös Elina Melginin analyysissä Guggenheim-museohankkeen viestinnästä. Legitimiteetti eli yleinen hyväksyntä on aina neuvottelukysymys sekä organisaatioissa että yhteiskunnassa laajemminkin, ja siksi eettiset kysymykset nousevat entistä suurempaan asemaan.

Läpinäkyvyydellä tavoitellaan hyötyjä, joita Petro Poutanen lähestyy innovaatioiden mahdollistamisen kautta. Avoimuuden noustessa globaaliksi trendiksi mahdollistuu organisaatioille myös innovaatioiden joukkoistaminen ja erilaisten innovaatioekosysteemien luominen. Organisaatioiden avoimuuteen kuuluukin avoimuuden kulttuurin edistäminen. Mutta olemmeko globaalissa rihmastoyhteiskunnassamme menettäneet jo aidon läpinäkyvyyden ja avoimuuden? Aki-Mauri Huhtinen päättää kirjan analysoimalla verkkomaailman ja informaatiomme saastumista. Elämä saastuneessa rihmastossa on viestinnällisesti haastavaa ja vaatii jatkuvaa tulkintaa ja analyysia.

Läpinäkyvyysyhteiskunnassa tarve viestinnän ammattilaisten osaamiselle on suuressa nousussa, sillä he osaavat tunnetusti analysoida ja tulkita ympäristöä ja sidosryhmien odotuksia. Toivotan sinulle menestystä tulevaisuuden roolissasi organisaatiosi ja koko toimialamme läpinäkyvyyslähettiläänä.

Jyväskylässä vähälumisen vapun tienoilla keväällä 2015,

\section{Vilma Luoma-aho}

Päätoimittaja

ProComma Academic 
KUKA?

Vilma Luoma-aho

- Vilma Luoma-aho (synt. 1977) on yhteisöviestinnän professori Jyväskylän yliopiston viestintätieteiden laitoksella. Ennen yliopistouraansa hän toimi viestinnän suunnittelijana ja tiedottajana sekä Suomessa että ulkomailla. Vilma on Helsingin ja Vaasan yliopistojen yhteisöviestinnän dosentti, ja hän on lanseerannut useita uusia käsitteitä kuten "Iuottojoukot" ja "teema-areenat". Hänen julkaisujaan löytyy sekä tieteellisistä journaaleista että alan kirjoista. Vilman kiinnostuksen kohteena ovat aineettomat pääomat ja sidosryhmien osallistaminen, ja hän johtaa parhaillaan kahta tutkimushanketta: HS-Säätiön rahoittamaa uusien mainostamisen muotojen läpinäkyvyystutkimusta sekä Tekesin rahoittamaa Hateholder-tutkimusta negatiivisien asiakaskokemuksien kääntämisestä positiiviseksi.

\section{LÄPINÄKYVÄÄ?}

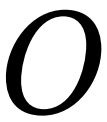

rganisaatioilta odotetaan yhteiskunnassamme eri asioita kuin vuosikymmen sitten. Vaikka avoimuus ja nopeus ovatkin hallinneet viestinnän ideaaleina jo pitkään, on näyttämölle astunut viime vuosien paljastusskandaalien, tietovuotojen ja yhä vahvistuvan faktantarkistustarpeen myötä uusi vaatimus: läpinäkyvyys. Läpinäkyvyyden tarve on kasvussa, koska sen puutteen on huomattu vaikeuttavan sekä yksilöiden, organisaatioiden että koko yhteiskunnan toimintaa. Yksilöiden eläessä entistä vahvemmin omissa viestintäkuplissaan valitsemiensa streamien ja feedejen armoilla, tulee keskeiseksi ymmärtää, kenen viestejä vastaan- 
otamme. Mediatutkimuksessa on jopa ehdotettu, että "läpinäkyvyys olisi uusi objektiivisuus", jolloin puolueettomuuden voisi korvata vain kertomalla avoimesti kaikki oleelliset sidokset ja vaikuttamisen keinot. Läpinäkyvyys toimii kuitenkin vain, jos sidosryhmät kokevat sen onnistuneen: enää ei riitä sen tiedon paljastaminen, jonka olettaa olevan tärkeää sidosryhmille. Ison datan aikakautena on tärkeää tuoda julki se, mitä sidosryhmät itse pitävät tärkeänä ja tarpeellisena. Viestintä ei ole enää organisaation kertomuksia itsestään, vaan vuoropuhelua sidosryhmien kanssa. Viestinnän ammattilaisten tehtäväksi nouseekin sidosryhmien läpinäkyvyysodotuksien monitorointi ja ymmärtäminen. Läpinäkyvyystarpeita ennakoivat organisaatiot pärjäävät tulevaisuudessa muita paremmin.

\section{Johdanto}

Läpinäkyvyys ei ole enää vain termi, joka toistuu juhlapuheissa ja yhteiskuntavastuuraporteissa, vaan siitä on tulossa yksi viestinnän perusvaatimus yhteiskunnassamme. Pohjoismaisissa yhteiskunnissa, joissa viestinnässä vallitsee avoimuusperiaate (Erkkilä 2012), avoimuus ja läpinäkyvyys ovat olleet jo pitkään yleisiä hyveitä, mutta myös suljetuimmissa ympäristöissä ne ovat nousemassa tärkeiksi. Läpinäkyvyys on yhdistetty myös toimivaan demokratiaan, yhteiskunnan kilpailukykyyn ja investointien määrään sekä jopa luottamuksen yleistymiseen yhteiskunnassa (Fukuyama 1996; Goede \& Neuwirth 2014).
Suomalaisen työn liiton kesän 2015 selvityksen mukaan suomalaisia ärsyttää yritystoiminnassa eniten juuri läpinäkyvyyden puute. Erityisesti vuoden 2015 aikana vahvistuneen vaikuttajaviestinnän nousu ja keskustelu sen ympärillä on korostanut läpinäkyvyyden merkitystä viestinnän ammattilaisten arjessa. Myös viestinnän ammattilaiset itse näkevät läpinäkyvyyden tärkeänä, sillä Viestintäpäivä PLUSSAssa 2014 keväällä kerätystä aineistosta tärkeimmäksi viestinnän särkymättömyyden kriteeriksi nousi juuri läpinäkyvyys ja siihen liittyvät teemat (Lahtinen \& Läärä, 2015). Työyhteisöviestinnässä organisaation sisäisien prosessien läpinäkyvyys on ratkaisevan tärkeässä asemassa. Great place to work -kilpailun viime vuosien voittajat hehkuttavat läpinäkyvyyden roolia menestyksessään, kun sisäiset huhut ja klikit vähenevät saman tiedon ollessa saatavilla kaikilla. Tutkimustulokset vahvistavat, että kun organisaation resursseja kuluu vähemmän sisäisen koheesion ylläpitoon ja valvontaan, luovuudelle ja ajattelulle vapautuu tilaa (Luoma-aho et al. 2012).

Wikileaksien ja Datadeskien aikakautena, kun kansalaiset, kuluttajat ja lukijat voivat itse tarkastaa faktoja, selvittää muiden kokemuksia ja jopa valokuvan aitoutta internetin kautta, on vaikutelmien merkitys ja ulkopuolisten sidosryhmien edustajien kokemus organisaation toiminnan läpinäkyvyydestä kasvanut. Organisaatioiden toiminnan tullessa yhä alastomammaksi eri sidosryhmien arvioille nousee keskiöön vahvan identiteetin rakentaminen ja kaiken toiminnan systemaattinen 
peilaaminen siihen. Jos teemme tämän päätöksen, onko se linjassa sen kanssa, mitä me lupaamme ja haluamme olla (Luoma-aho \& Paloviita 2010)? Voiko tästä päätöksestä olla ylpeä, jos ja kun se leviää julkisesti kaikkien tietoon? Yhä tärkeämmiksi nousevat käsitykset organisaation identiteetistä, sen ajamista asioista ja sen toiminnan läpinäkyvyydestä.

Läpinäkyvyyden vaatimuksia on esitetty sekä yksilöiden, organisaatioiden ja instituutioiden että valtioiden tasolla. Viime vuosien vaalirahoituskeskustelu ja tukien läpinäkyvyys ovat hyviä esimerkkejä siitä, miten läpinäkyvyys käytännössä vaatii sekä yksilön, organisaatioiden että yhteiskunnan yhteistyötä. Läpinäkyvyysvaatimukset koskevat myös tuotteita ja palveluita: sidosryhmät haluavat tietää, mistä tuote on valmistettu, kuka siihen on osallistunut, miten heitä on kohdeltu, kenelle voitot menevät ja miten epäkohtiin puututaan, jos sellaisia löytyy. Vuoden 2014 Slush-tapahtumassa Helsingissä esiteltiin läpinäkyvyyttä lisääviä sovelluksia, jotka selvittävät reaaliajassa esimerkiksi, mitä aineisosia jokin vaikeaselkoinen tuote oikeasti sisältää tai missä se on valmistettu. Viestinnän todenmukaisuus ja aitous tulee testattua tulevaisuudessa reaaliajassa. Miten suunnitella viestintää tulevaisuudessa, kun kiinnostuneet voivat selvittää yhdellä vilkaisulla organisaation työntekijöiden määrän lisäksi sen liikevoiton, ylimmän johdon työmatkojen hiilijalanjäljen, sosiaalisen saasteen asteen (tulevaisuuden mittari siihen, miten paljon esim. ylityö saastuttaa hyvinvointia) ja keskijohdon ja sihteerien työtyytyväisyysluvut?
Läpinäkyvyydelle on nousemassa myös median puolella uusia haasteita: yhteistyö sisällöntuotannon piirissä mediaorganisaatioiden kanssa. Kun sisältöä tuotettaessa mainostaminen, markkinointi, viestintä ja journalismi alkavat sekoittua brändijournalismin ja natiivimainonnan myötä, herää sidosryhmien valppaus: kuka minulle viestii ja mitä hän sillä tavoittelee? Odotuksien ennakoinnista onkin tulossa kilpailuetu, jota on vaikea voittaa. Muutoksia on tapahtumassa myös sidosryhmissä itsessään: kun ns. milleniaalisukupolvet, jotka ovat kasvaneet informaatioyhteiskunnassa, tulevat lähivuosina täysi-ikäisiksi, muuttuvat sidosryhmien odotukset organisaatioita kohtaan entistä vahvemmin "kaikki on julkista"-ajattelun suuntaan vanhan "se on julkista, mitä päätetään julkaista" -ajattelun sijasta (Muntinga, Moorman \& Smit 2011; BBMG 2011). Mitä bloggaaja saa yritykseltä lahjaksi kirjoituksistaan? Onko organisaatio sanojensa takana, kun lupaa toiminnan vastaavan kestävän kehityksen kriteerejä? Mistä tiedämme, ovatko ravintolaa ylistävät palautteet fakeholdereiden eli teennäisten sidosryhmien tuottamia ja ostettuja?

\section{Viestinnän ammattilaisten tehtä-} väksi onkin nousemassa sidosryhmien läpinäkyvyysodotuksien monitorointi (Albu and Wehmeier,2014; Rawlins 2008). Viestinnän ammattilaisten toimenkuvaa kansainvälisesti linjaavan Melbournin mandaatin (2012) mukaan organisaation olemassaolo eli legitimiteetti vaatii syntyäkseen läpinäkyvää viestintää, vastuullisuutta sekä sen viestimistä, mitä lisäarvoa organisaatio yhteiskunnalle ja sidosryh- 
mille tarjoaa. Näiden selvittäminen on kuitenkin helpommin sanottu kuin tehty, sillä käsitykset läpinäkyvyydestä ovat yksilöllisiä ja sidottuja aikaan ja kontekstiin.

Läpinäkyvyyden viestinnässä on voimassa ns. "kultakutrisääntö": sitä ei saa olla liikaa, eikä sitä saa olla liian vähän (Carroll \& Einwiller 2014). Liian vähäinen läpinäkyvyys toiminnassa tai tiettyjen yksityiskohtien poisjättäminen herättää syytökset salailusta, kun taas liian suuri tiedonmäärä hukuttaa tärkeän tiedon. Molemmista seuraa mainehaittoja. Optimitason löytäminen vaatii kuitenkin ympäristön kuuntelua ja odotuksien selvitystä. Oleellista on se, miltä läpinäkyvyys vaikuttaa ulospäin eri sidosryhmille (Molleda 2010; Shen \& Kim 2012). Vaikka näihin vaikutuksiin ei suoraan voi vaikuttaa, ovat sidosryhmien odotukset kuitenkin ohjailtavissa, sillä ne muodostuvat etupäässä aikaisempien kokemuksien ja organisaation toiminnan ja viestinnän perusteella.

Läpinäkyvyys voidaan määritellä pyrkimykseksi paljastaa organisaation toimintaa ja altistaa se ulkopuolisten arvioinnille. Sellainen läpinäkyvyys, joka vaatii ylimääräisiä selityksiä ja selvityksiä, ei ole läpinäkyvyyttä, vaan epäonnistunutta signalointia. Strateginen epäselvyys ja vaikeiden asioiden piilottaminen tietomassaan ovat eettisesti epäilyttäviä, tosin usein viestinnän ammattilaiselle vastaan tulevia arjen haasteita. Läpinäkyvyydessä voidaankin erottaa kaksi eri näkökulmaa: se, mitä organisaatio itse pitää läpinäkyvyytenä ja se, mitä sidosryhmät kokevat läpinäkyvyytenä. Näiden saattaminen yhteen vaatii viestinnän ammattilaisilta jatkuvaa työtä.

\section{Kaksi eri näkökulmaa läpinäkyvyyteen}

Käyttäytymistaloustieteen ajattelun mukaan ihmisen käyttäytymiseen vaikuttaa yhdeksän tekijää: viestin tuoja, kannustimet, normit, oletettu toiminta, valinnan sujuvuus, tunteet, houkuttelevuus, kehystys, sitoutuminen ja oma ego (Dolan et al. 2012). Näin ajateltuna yksilöt ja organisaatiot muuttavat toimintaansa läpinäkyväksi vain, jos sen edellytykset täyttyvät. Mielenkiintoista on, että yhden tekijän noustessa erityisen polttavaksi löytävät ihmiset itselleen perusteluita muidenkin tekijöiden suhteen helpommin.

Peilattaessa nyky-yhteiskuntaamme voidaan ajatella, että tällä hetkellä organisaatioiden viestinnän läpinäkyvyyteen nähdään jo yleistä kiinnostusta, ja vahvana muutosta tukevina tunteina toimivat sekä pelko (tietovuodot, kalastelu) että toiveikkuus saavuttaa kilpailuetua ja parantaa mainetta. Houkuttelevuus on haastettuna, sillä läpinäkyvyydestä aiheutuu selviä kustannuksia ja myös haittoja, kuten prosessien kulun avaaminen, perustelujen tuottaminen ja entistä tarkempi eettisten kysymyksien pohdinta. Läpinäkyvyys on tällä hetkellä myös kehystetty melko negatiivisesti: lähinnä riskeillä siitä, mitä seuraa, jos ei toimi läpinäkyvästi. Valinnan sujuvuuskaan ei ole helppoa, sillä käytössä olevat johtamismallit ja järjestelmät eivät tue avointa viestintää. Oman haasteensa tuo sekin, että viestintuojat ovat usein vapaaehtoisen raportoinnin puolestapu- 
hujia, ja vaikutusvaltaisien sidosryhmien, kuten maksavien asiakkaiden tai sijoittajien, tarve läpinäkyvyydelle on vasta muodostumassa. Kannustimia ei ole vielä kunnolla löydetty, vaikka läpinäkyvyyden onkin todettu vaikuttavan organisaation työtyytyväisyyteen. Sitoutuminen on siis vasta muodostumassa, ja harvalla yrityksellä läpinäkyvyys vielä liittyy sen identiteettiin yhtä vahvasti kuin Great place to work -kilpailun voittajilla.

Viestitty läpinäkyvyys onnistuu vain, jos se kohtaa organisaatioon kohdistetun tiedontarpeen. Haasteita viestinnän läpinäkyvyydelle tuovat sekä ihmisen ajattelumallit että vallalla olevat viestinnän trendit. Tarinamuotoinen kertominen on valtaamassa alaa viestinnässä, sillä tarinat jäävät mieleen paremmin kuin faktat. Käyttäytymistaloustieteilijät selittävät tätä sillä, että visuaalisesti kuvitellut yksityiskohdat aktivoivat faktoja enemmän aivojamme ja pidämme niitä tutumpina ja siten totuudenmukaisempina (Thaler \& Sunstein 2010).

Se, että organisaatio raportoi läpinäkyvästi toiminnastaan ei luo lisäarvoa, jos toiminta ei vastaa sidosryhmien odotuksia tai läpinäkyvyysvaatimuksia (Olkkonen \& Luoma-aho 2012). Läpinäkyvyydessä voidaankin erottaa kaksi eri näkökulmaa:

\section{1) viestitty läpinäkyvyys}

(signaalit, joita organisaatiot lähettävät viestinnässään) ja

\section{2) koettu läpinäkyvyys}

(signaalit, joita sidosryhmät tulkitsevat läpinäkyvyydeksi).
Kiinnostavaa on, että yhteiskuntamme on muuttanut radikaalisti viime vuosien aikana juuri läpinäkyvyyden kokemuksen kriteerejä, kun taas viestitty läpinäkyvyys näyttäisi muuttuvan hitaammin. Sidosryhmien odotukset kasvavat koko ajan, ja viestinnän ammattilaisten tehtäväksi onkin nousemassa toimiminen sidosryhmien odotuksien ja organisaation toiminnan välisenä tulkkina. Taulukko 1 summaa eroja viestityn ja koetun läpinäkyvyyden välillä.

Läpinäkyvyys on erityisen tärkeää huonojen uutisten kohdalla. Vanha kriisija poikkeustilaviestinnän ohje kaiken kertomisesta heti ja avoimesti on myös läpinäkyvyyden viestintään pätevä neuvo. Esimerkiksi irtisanomisien määrä tuntuu pienemmältä, jos sen kehystää tarinaan, jossa kerrotaan vuoden vastoinkäymisistä, peilataan oman organisaation tilannetta muihin alan toimijoihin ja kerrotaan, miten niitä on kompensoitu. Läpinäkyvyyden nimissä fakta ei kuitenkaan muutu: irtisanottavien määrä on edelleen sama, avattiin sen kontekstia tai ei. Jos kehystarina koetaan liian harhaanjohtavaksi, nousee syytös tiedon piilottamisesta.

Läpinäkyvyydessä on kyse myös aitoudesta (Molleda 2010), ja silloin kun luodaan kehystarinaa, painottuu aina jonkun näkökulma toisten kustannuksella. Onnistuneen viestinnän kriteereihin kuuluukin viestin resonoiminen sidosryhmien kokemuksien kanssa. Jos sidosryhmillä on käsitys, että monet irtisanovat, ja että kyseinen organisaatio on aikaisemmin kohdellut työntekijöitään hyvin, onnistuu viestintä irtisanomisista helpommin. Jos taas sidos- 


\section{O, / 17}

Viestitty läpinäkyvyys

(organisaation näkökulma)

\begin{tabular}{|c|c|c|}
\hline Mitä tarkoittaa? & $\begin{array}{l}\text { Mitä osa-alueita toiminnasta } \\
\text { kerrotaan ulkopuolisille }\end{array}$ & $\begin{array}{l}\text { Mitä organisaatio } \\
\text { "oikeasti tekee" }\end{array}$ \\
\hline Mihin vaikuttaa? & Parantaa mainetta & Lisää luotettavuutta \\
\hline Mistä löytyy? & $\begin{array}{l}\text { Virallisista dokumenteista: } \\
\text { kirjataan raportteihin ja selvityksiin } \\
\text { sekä laatukriteereihin ja mainitaan } \\
\text { palkintopuheissa tai suosituksista }\end{array}$ & $\begin{array}{l}\text { Asiakaskokemuksista: } \\
\text { etsitään asiakaspalautteista } \\
\text { ja muiden kokemuksista }\end{array}$ \\
\hline $\begin{array}{l}\text { Miten arvioidaan } \\
\text { muutosta? }\end{array}$ & Verrataan aikaisempiin raportteihin & $\begin{array}{l}\text { Verrataan muihin saman- } \\
\text { tyylisiin toimijoihin }\end{array}$ \\
\hline Oletus? & $\begin{array}{l}\text { Pieniäkin parannuksia arvostetaan } \\
\text { ja ne huomataan }\end{array}$ & $\begin{array}{l}\text { Organisaatio parantaa } \\
\text { toimintaa vain pakon edessä }\end{array}$ \\
\hline Suhteessa? & $\begin{array}{l}\text { Yksi hyvä käytäntö kaikkien } \\
\text { palveluiden joukossa }\end{array}$ & $\begin{array}{l}\text { Saattaa ratkaista } \\
\text { asiakkuuden }\end{array}$ \\
\hline
\end{tabular}

\section{Taulukko 1.}

Eroja organisaation viestimän läpinäkyvyyden ja sidosryhmien kokeman läpinäkyvyyden välillä.

ryhmien keskuudessa vallitsee käsitys, että kyseinen organisaatio ei ole aikaisemmin kohdellut työntekijöitään hyvin ja että monet organisaatiot eivät irtisano vaikka voisivat, on haastavaa saada sidosryhmät ymmärtämään viestiä irtisanomisien tarpeellisuudesta. Aikaisemmalla toiminnalla ja maineella on entistä suurempi merkitys, kun arvioidaan organisaation viestinnän aitoutta ja läpinäkyvyyttä (Molleda 2010; Shen \& Kim 2012).
Koettu läpinäkyvyys

(sidosryhmien näkökulma)

Mitä organisaatio

"oikeasti tekee"

Lisää luotettavuutta

Asiakaskokemuksista:

etsitaän asiakaspalautteista

ja muiden kokemuksista

Verrataan muihin saman-

tyylisiin toimijoihin

Organisaatio parantaa

toimintaa vain pakon edessä

Saattaa ratkaista

asiakkuuden
Läpinäkyvyys on lupaus sidosryhmille: olemme sitä, mitä kerromme olevamme. Samalla läpinäkyvyysviestintä on aina avoin kutsu sidosryhmille arvioida organisaation toimintaa. Jos erot käytännön toiminnan ja viestien välissä ovat sidosryhmien mielestä liian suuret, voivat seuraukset olla organisaatioille vaikeita. Esimerkiksi meemit ja brändin- tai hashtagin kaappaukset selittyvät osin sillä, että organisaation viestintä pyytää sidosryhmiä nostamaan 
esiin sellaisia tunteita ja kokemuksia, jotka eivät resonoi sidosryhmien omiin käytännön kokemuksiin. Haastavia esimerkkejä on löydettävissä paljonkin: Kun McDonald's pyytää kertomaan hashtagilla \#McDstories kokemuksia ravintoloista, täyttyvät viestit negatiivisista kokemuksista ja likaisen lattian kuvista. Kun Lahden kaupunki pyrkii keräämään mukavia turismikokemuksia hashtagilla \#visitLahti, tulee feediin mukaan vessanseinäkirjoituksia ja sammuneita alkoholisteja. Vaikka täysin positiivista vaikutelmaa ei ehkä koskaan voidakaan saada, on tärkeää ymmärtää, mitä sidosryhmät ajattelevat, ennen kuin heidät valjastaa osallistumaan organisaation viestintään.

\section{Läpinäkyvyyden inflaatio}

Kuten kaikilla trendisanoilla, läpinäkyvyydelläkin on alkamassa inflaatio. Kun läpinäkyvyydestä on tulossa yleissana, on riskinä se, ettei se kuvaa enää tarkasti mitään: läpinäkyvyydellä voidaankin tarkoittaa kaikkea yrityksen budjetin avaamisesta ruokapaikkojen listaamiseen. Samalla kun läpinäkyvyys kasvaa, eettisien kysymyksien määrä myös lisääntyy, sillä sidosryhmien tulkinnat vaihtelevat (De Tienne \& Lewis 2005). Se, mitä organisaatio pyrkii viestimään läpinäkyvyytenä, voi sidosryhmien kokemuksissa näyttäytyä huomion siirtämisenä muihin asioihin. Aikaisemmilla kokemuksilla onkin ratkaiseva rooli, kun läpinäkyvyyttä arvioidaan, ja jatkuva hyvä toiminta onkin ainoa tapa rakentaa sidosryhmien odotuksia vastaavaa läpinäkyvyyttä.

Lisäksi sidosryhmien kasvavista odo- tuksista huolimatta voidaan nähdä, että läpinäkyvyysvaatimuksien loppukäyttäjinä ovat edelleen useimmiten muut organisaatiot, erilaiset analyytikot ja arvioinnin ammattilaiset, eikä yksittäisillä sidosryhmien edustajilla ole niin selvää vaikutusta kuin usein ehdotetaan (Fung 2013).

\section{Mitä tämä tarkoittaa käytännössä?}

Käsitys läpinäkyvyydestä rakennetaan etukäteen. Läpinäkyvyyttä ei voi siis ostaa tilannekohtaisesti, vaan se syntyy pitkällä aikavälillä kokemuksien kautta. Kokemuksiin tosin vaikuttavat itse organisaation lisäksi myös alan muut toimijat ja sektorimaine, ja näiden ollessa ristiriidassa jää sidosryhmille enemmän epäselvyyttä ja tarvetta selvittää käsityksiään. Lopullisesti läpinäkyvyyden tarve vahvistuu vasta, kun käyttäytymiseen vaikuttavat tekijät täyttyvät (Dolan 2012). Näistä ajankohtaisiksi organisaation viestinnän läpinäkyvyyden suhteen nousevat ainakin kannustimet, normit, se kuka asiasta kertoo, valinnan sujuvuus ja houkuttelevuus.

Monet organisaatiot kokevat olevansa jo varsin läpinäkyviä käytännöissään. Läpinäkyvyyden paras testi on kysyä suoraan omalta henkilöstöltä sekä eri sidosryhmiltä, onko heille selvää, miten organisaatio toimii ja miksi. Mikäli heillä ei ole selvyyttä organisaation toiminnan logiikasta, voidaan olla läpinäkyvyyden kohdalla haasteen edessä: odotukset voivat ohjata sidosryhmien arvioita väärään tai jopa epärealistiseen suuntaan.

Läpinäkyvyydestä voidaan linjata seuraavaa suhteessa organisaatioiden viestintään: 


\section{1) Luottamuksellisuuden käsite on vanhentumassa}

Organisaatioiden on tulevaisuudessa varauduttava siihen, että tietoja ja osaamista voidaan yhä vähemmän pitää salaisena tai luottamuksellisena sekä teknologian kehityksen myötä että muuttuneiden läpinäkyvyysodotuksien takia. Merkkejä on jo nähtävissä siitä, että mitä tärkeämmästä tai arkaluontoisemmasta tiedosta on kyse, sitä suuremmalla innolla erilaiset hakkerit, tietovuotajat ja totuudenselvittäjät sitä lähestyvät.

\section{2) Läpinäkyvyys organisaation vies-} tinnässä toimii vain, kun se vastaa sidosryhmien odotuksia

Sidosryhmien odotukset ohjaavat heidän tulkintojaan organisaation läpinäkyvyydestä, ja sellaisien asioiden paljastaminen, jotka eivät kiinnosta sidosryhmiä, on turhaa. Väärien asioiden avaaminen muiden nähtäväksi saattaa jopa aiheuttaa negatiivisia reaktioita sidosryhmissä. Ne organisaatiot, jotka osaavat ennakoida sidosryhmien läpinäkyvyystarpeita, saavat etumatkaa.

\section{3) Läpinäkyvyyden odotuksia ei voi} hallita, mutta niihin voi vaikuttaa omalla toiminnallaan

Kokemus läpinäkyvyydestä ei muodostu tyhjiössä, vaan sektoreittain ja aikaisemman toiminnan valossa. Viestinnän ammattilaiset ovat keskeisessä roolissa tässä odotusten hallinnassa (Olkkonen \& Luoma-aho 2014), sillä heillä on ko- kemusta dynaamisesta sidosryhmätyöstä pitkällä aikavälillä. Yksi uusi viestinnän ammattilaisten työtehtävä onkin juuri odotuksien hallinta ja sen kautta sidosryhmien läpinäkyvyystarpeiden ennakointi.

4) Läpinäkyvyydellä voidaan rakentaa organisaation sosiaalista pääomaa Organisaatioiden sosiaalinen pääoma muodostuu sen sidosryhmien halukkuudesta yhteistyöhön ja niiden luottamuksesta organisaatiota kohtaan. Avainasemassa ovat organisaation omat työntekijät. Heidän kokemuksensa läpinäkyvyydestä ovat erityisen tärkeitä, sillä he toimivat yrityksen edustajina ja maineen suurlähettiläinä joka päivä työssään ja lisääntyvässä määrin myös vapaa-ajallaan.

Parantamalla läpinäkyvyyttä sekä organisaation toiminnassa yleisesti että viestinnässä voidaan parantaa sekä sisäisten sidosryhmien että ulkoisten sidosryhmien tyytyväisyyttä. Läpinäkyvyydellä voidaan siis parhaimmillaan rakentaa organisaation sosiaalista pääomaa. Tämä pääoma on organisaatioille erityisen arvokasta nykyisessä muuttuvassa ympäristössämme, jossa tapahtuu yllättäviä käänteitä ja muutoksia.

\section{Näistä voit aloittaa:}

1) BBMG (2011). Unleashed: How New Consumers Will Revolutionize Brands and Scale Sustainability. Tiivistelmä saatavilla verkossa: http://www.csrwire. com/press_releases/31854-BBMG-New- 
Consumer-Will-Bring-Sustainabilityto-the-Mainstream

2) World Public Relations Forum (2012). The Melbourne Mandate: A call to action for new areas of value in public relations and communication management. Saatavilla verkossa: http://melbournemandate.globalalliancepr.org/wp-content/uploads/ 2012/11/Melbourne-Mandate-Text-final. pdf

\section{Lähteet}

Albu, O. \& Wehmeier, S. (2014). Organizational Transparency and Sense-Making: The Case of Northern Rock. Journal of Public Relations Research, 26(2), 117-133.

Carroll, C. \& Einwiller, S. (2014). Disclosure Alignment and Transparency Signalling in CSR Reports. Hart, (Toim.) Communication and Language Analysis in the Corporate World, s. 249-270. Hershey, PA: IGI-Global.

Chen C. P. (2013). Exploring Personal Branding on YouTube. Journal of Internet Commerce, 12 (4), 332-347.

DeTienne, K. \& Lewis, L. (2005). The Pragmatic and Ethical Barriers to Corporate Social Responsibility Disclosure: The Nike Case. Journal of Business Ethics, 60, 359-376.

Erkkilä, T. (2012). Government Transparency. Impacts and Unintended Consequences. Palgrave Macmillan, Basingstoke.
Fung, A. (2013). Infotopia: Unleashing the Democratic Power of Transparency*. Politics \& Society 41(2) 183-212.

Goede, M \& Neuwirth R. (2014). Good governance and confidentiality: a matter of the preservation of the public sphere. Corporate Governance 14(4), 543-554.

Howe, N. \& Strauss, W. (2000). Millennials rising: The next great generation. New York: Vintage Books.

Lahtinen, M. \& Läärä, L. (2015). Viestinnän ammattilaisten käsityksiä särkymättömästä viestinnästä. Yhteisöviestinnän kandidaatintutkielma, Viestintätieteiden laitos, Jyväskylän yliopisto. Julkaisematon.

Luoma-aho, V. \& Vos, M. (2010). Towards a more dynamic stakeholder model: Acknowledging multiple issue arenas. Corporate Communications: An International Journal 15(3), 315-331.

Luoma-aho, V. \& Paloviita, A. (2010). Actor-networking stakeholder theory for corporate communications Corporate Communications: An International Journal 15(1), 47-69.

Luoma-aho, V., Vos, M., Lappalainen, R., Lämsä, A.-M., Uusitalo, O., Maaranen, P. \& Koski, A. (2012). Added value of intangibles for organizational innovation. Human Technology: An Interdisciplinary Journal on Humans in ICT Environments 8(1), 7-23. 
Molleda, J. (2010). Authenticity and the construct's dimensions in public relations and communication research. Journal Of Communication Management 14(3), 223-236.

Muntinga, D. G., Moorman, M. \& Smit, E. G. (2011). Introducing COBRAs: Exploring motivations for brand-related media use. International Journal of Advertising 30(1), 13-47.

Prensky, M. (2001). Digital natives, digital immigrants part I. On the Horizon 9(5), $1-6$.

ProCom (2012) Kohti vuotta 2020. Strategista viestintää ja leimahtavia julkisuuksia. ProCom Yhteisöviestinnän periaatteet.

Rawlins, B. (2008). Measuring the relationship between organizational transparency and employee trust. Public Relations Journal 2(2), 1-21.

Rawlins, B. (2009). Give the Emperor a Mirror: Toward Developing a Stakeholder Measurement of Organizational Transparency. Journal Of Public Relations Research 21(1), 71-99.

Selwyn, N. (2009). The digital native Myth and reality. Aslib Proceedings 61(4), 364-379.

Shen, H., \& Kim, J. (2012). The Authentic Enterprise: Another Buzz Word, or a True Driver of Quality Relationships? Journal of Public Relations Research 24(4), 371-389.
Siegrist, M. \& Cvetkovich, G. (2001). Better Negative than Positive? Evidence of a Bias for Negative Information about Possible Health Dangers. Risk Analysis 21(1), 199-206.

Simon, H.A. (1971). Designing Organizations for an Information-Rich World. Baltimore, MD: The Johns Hopkins Press.

Tapscott, D. (2009). Grown up digital: How the net generation is changing your world. New York: McGraw-Hill.

The Melbourne Mandate (2012): A call to action for new areas of value in public relations and communication management. World Public Relations Forum, November 2012. Available online: http://melbournemandate.globalalliancepr.org/wp-content/ uploads/2012/11/Melbourne-Mandate-Text-final.pdf 


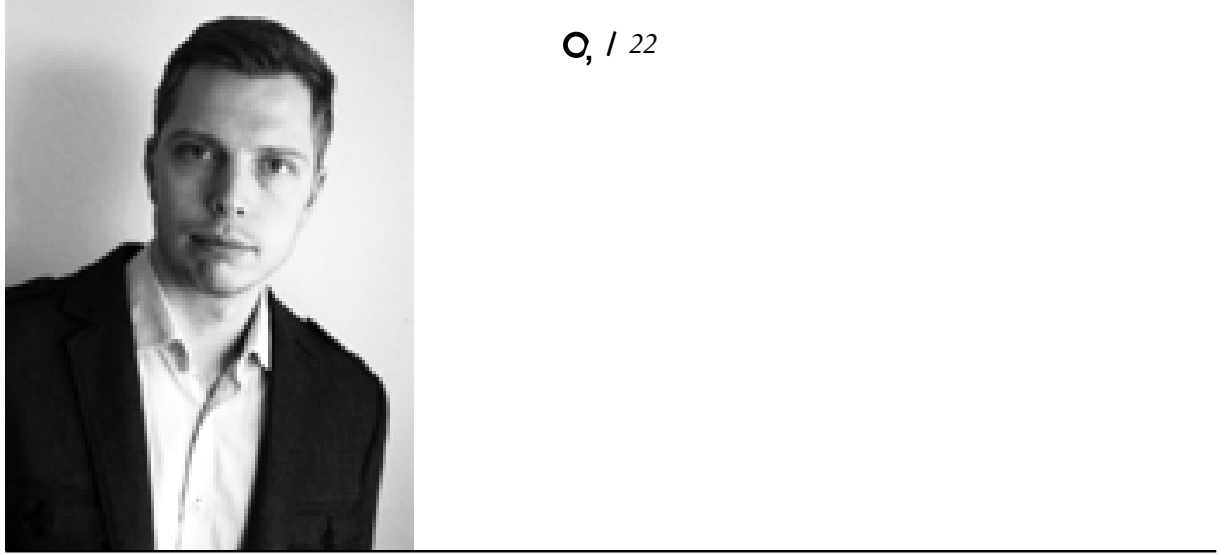

KUKA?

Kimmo Taiminen

- Kimmo Taiminen, KTM, FM on yhteisöviestinnän tohtorikoulutettava Jyväskylän yliopistossa. Hän tutkii väitöskirjassaan kaupallisten hybridisisältöjen läpinäkyvyyttä.

Tällä hetkellä Kimmo toimii projektitutkijana kuluttajien verkkokäyttäytymistä tutkivassa DIGA-hankkeessa Jyväskylän yliopiston kauppakorkeakoululla. Hankkeessa hän tutkii kuluttajakokemuksia ja kuluttajien sitoutumista sekä niiden vaikutuksia yritykselle. Kimmolla on kokemusta myös sisältöstrategioiden parissa työskentelystä, ja hän on konsultoinut ja luennoinut sidosryhmien sitouttamisesta erilaisten sisältöjen avulla.

\section{MAKSETTUJEN MEDIA- SISÄLTÖJEN LÄPINÄKYVYYS}

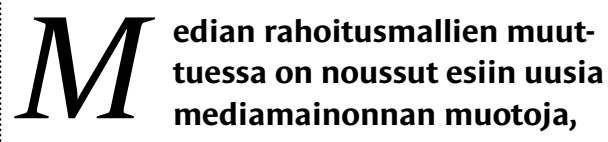
kuten natiivimainonta ja sponsoroitu sisältö. Kun trendinä on ollut tehdä mainonnasta median alkuperäisen sisällön kaltaista, läpinäkyvyyden tarve maksetuissa mediasisällöissä on noussut keskeiseen asemaan. Tästä syystä yhteiskunnan toimijoiden on tärkeää nostaa esiin kysymys siitä, mitä läpinäkyvyys oikein on ja millaisina toimina sen pitäisi näyttäytyä sidosryhmille. Aidon läpinäkyvyyden turvaamiseksi olisikin hyvä olla tietoisia niistä päämääristä, ajatusmalleista sekä ammatillisista odotuksista, joita uusien mediamainonnan muotojen saralla toimivilla 
on. Viestinnän ammattilaisten on kyettävä myös arvioimaan etukäteen, millä tavalla jokin läpinäkyvyyden elementti vaikuttaa sidosryhmän kokemukseen, sillä piilomainontaa muistuttava toiminta uhkaa sekä organisaation, median että itse viestintämenetelmän uskottavuutta.

\section{Johdanto}

Läpinäkyvyyden painoarvo on korostunut internetin ja sosiaalisen median myötä. Brändien ja organisaatioiden on täytynyt valpastua uudella tavalla läpinäkyvyyden vaatimuksiin, sillä harhaanjohtava toiminta voi leimata brändin hyvinkin nopeasti kohderyhmien mielissä epäaidoksi tai epäluotettavaksi, jolloin organisaation uskottavuus ja maine voivat kärsiä. Vaikka käsite vaikuttaa itsestäänselvältä, se ymmärretään kuitenkin monin eri tavoin (Rawlins 2009), kuten avoimuuden synonyyminä (Albu \& Wehmeier 2014) tai jopa pelkkänä viestinnän totuudenmukaisuutena (Taiminen et al. tulossa).

Läpinäkyvyyden tarkastelu on tärkeää myös viime aikoina kasvaneeseen natiivimainontaan ja sponsoroituun sisältöön liittyen. Erilaisiin brändättyihin sisältöihin viittaavia käsitteitä on runsaasti (esim. brändijournalismi, sisältömarkkinointi), ja niitä käytetäänkin usein ristiin. Sponsoroidun sisällön voi ajatella sisältävän kaiken organisaatiolle maksua vastaan tuotetun sisällön esittämisen ulkoisessa lähteessä (Sonderman \& Tran 2013). Nativiimainonta taas voidaan nähdä maksettuna sisältönä, joka on samankaltaista alkuperäisen sisällön kanssa, ulkoasultaan yhtenäistä muuhun sivuston sisältöön nähden ja jonka luonne siten vaihtelee mediakontekstin mukaan (Interactive Advertising Bureau 2013b).

Käytännössä uusi mainonta ilmenee siis erilaisina sisältöinä; maksettuina palasina uutisvirrassa, maksettuina hakutuloksina tai maksettuina sisältöinä journalistisessa sisällössä. Natiivimainonta ja sponsoroidut sisällöt ovat erityisen kovassa huudossa nyt, sillä ne koetaan vähemmän ärsyttävinä perinteiseen keskeyttävään mainontaan verrattuna (Tutaj \& van Reijmersdal 2012). Maksettujen mediasisältöjen arvo brändeille ja organisaatioille on siinä, että ne voivat luoda ja korostaa asiantuntijuuttaan ja mielipidejohtajuuttaan alustoilla, joihin traditionaalisesti vain journalisteilla on ollut pääsy (Luoma-aho \& Taiminen, 2014). Kuvio 1. avaa maksettujen mediasisältöjen uskottavuutta ja identifioitavuutta. 


\section{Kuvio 1.}

Eri maksettujen mediasisältömuotojen identifioitavuus (tunnistettavuus brändisisällöksi) ja uskottavuus (sisällön laatu + konteksti + identifioitavuus).

\section{BRÄNDIJOURNALISMI}

Journalistisen sisällöntuotannon periaatteita noudattavaa, omistetussa tai maksetussa mediaympäristössä esiintyvää ja kohderyhmän tiedontarpeisiin vastaavaa sisältöä.

\begin{abstract}
SPONSOROITU SISÄLTÖ
Brändille maksua vastaan ulkoisessa mediaympäristössä tuotettua ja esitettyä sisältöä, johon brändi assosioituu.
\end{abstract}

\section{NATIIVIMAINONTA}

Mediaympäristöön sopivaa, alkuperäisen sisällön kanssa samankaltaista, ulkoasultaan yhtenevää, maksettua mainontaa, joka ei keskeytä lukijan käyttökokemusta.

\section{SISÄLTÖMARKKINOINTI}

Usein brändin itsensä tuottamaa kohderyhmää houkuttelevaa sisältöä brändin omiin kanaviin, jonka tarkoituksena on olemassa olevien asiakkaiden sitouttaminen ja uusien asiakkaiden hankinta.

\section{ADVERTORIAALI}

Maksettua brändipromootioon perustuvaa mainostilaa, josta on tehty mahdollisimman samankaltaista ja ulkoasultaan yhtenevää journalistisen sisällön kanssa ja jossa brändi on tarkoituksella "liitetty" osaksi tarinaa. 
Natiivimainonnan kehitys on nostanut esiin huolen siitä, voivatko jotkin organisaation tuottamat verkkosisällöt johtaa sidosryhmiä harhaan esimerkiksi sisällyttämällä riippumattomina pidettyihin medioihin organisaation suostuttelevia viestejä. Onkin tarpeellista huomioida, että mainonta on suostuttelua, jossa viestintää voidaan ja käytetään organisaation tai brändin oman edun tavoitteluun (Kaler 2000). Eettisesti arveluttavia ylilyöntejä on jo sattunut, joista kuuluisin lienee the Atlanticin julkaisema skientologikirkon natiivimainos (kts. Moses 2013), jossa muun muassa lukijoiden kommentteja moderoitiin, jotta tekstistä saatiin mahdollisimman vakuuttava.

Yksi tärkeä läpinäkyvän toiminnan perusperiaate onkin tarjota lukijoille tarpeeksi tietoa, jotta nämä voivat ymmärtää ja arvioida itse organisaatioiden toimintaa (Rawlins 2009; Baker 2008). Verkkomedian ja -mainonnan nopeassa kehityksessä ei voida kuitenkaan olla varmoja siitä, ovatko lukijat pysyneet mukana kehityksessä ja ovatko he tarpeeksi valppaita ymmärtämään uusia mainonnan muotoja (Drumwright \& Murphy 2009; Tutaj \& van Reijmersdal, 2012). Läpinäkyvyys on läpinäkyvyyttä vain, jos se ymmärretään. Eettisesti vahvalla pohjalla oleva natiivimainonta on merkitty niin hyvin, että se auttaa lukijoita ymmärtämään, mille he altistuvat. Tätä kautta läpinäkyvyys toimii myös yhtenä tärkeänä tukipilarina organisaation legitimiteetin (Tomažic, Boras, Jurišic \& Lesjak 2014) ja sidosryhmien luottamuksen takaamisessa (Rawlins 2009).

\section{Sisältöjen läpinäkyvyys}

Viime aikoina usein käytetty läpinäkyvyyden määritelmä viestinnän kirjallisuudessa kuvaa läpinäkyvyyden "harkituksi pyrkimykseksi tuoda saataville kaikki laillisesti julkistettavat tiedot - luonteeltaan niin positiiviset kuin negatiivisetkin - tavalla, joka on tarkkaa, oikea-aikaista, tasapuolista ja yksiselitteistä, tukea yleisön päättelykykyä ja pitää organisaatio vastuullisena heidän tekemisistään, linjoistaan ja menettelytavoistaan" (Rawlins 2009). Jotta organisaatio onnistuu luomaan tarvittavan läpinäkyvyyden asteen omalle toiminnalleen, sen tulee kyetä tietoisesti arvioimaan omaa viestintäänsä. Läpinäkyvä viestintä on tärkeä osa sidosryhmäsuhteita ja perustuu organisaation pyrkimykseen toimia aidosti ja autenttisesti (Molleda 2010). Läpinäkyvyyden vastakohdaksi onkin ehdotettu salailua (Rawlins 2009) tai teeskentelyä (Carroll \& Einwiller 2014), jolloin asioita nimenomaan jätetään viestimättä tai ne viestitään puutteellisesti.

Viestintä- ja media-alalla on vahvat perinteet eettisiin normeihin pohjautuvaan itsesäätelyyn. Läpinäkyvyys onkin osa viestintäetiikkaa ja vastuullisuutta (Baker 2008). Eettiseltä kannalta läpinäkyvyyteen liittyy sidosryhmien ymmärryksen parantaminen ja erityisesti organisaation itsensä asettaminen vastuulliseksi toimijaksi, sillä avoin, läpinäkyvä viestintä tuo esiin myös organisaation vastuut (Rawlins 2009; Plaisance 2000). Tästä syystä myös viestinnän läpinäkyvyyttä arvioitaessa on syytä ottaa huomioon viestijän ammattietiikka ja se, missä määrin lukija voi pitää toimintaa 
eettisenä ja moraalisena (Bowen 2004). Läpinäkyvyys ja erityisesti itsensä vastuulliseksi tekeminen (accountability) näyttäytyvätkin monesti eettisinä koodistoina ja ammattinormeina.

Olennaisen informaation viestintä sidosryhmille on keskeinen osa läpinäkyvyyttä (Rawlins 2009; Baker 2008; Schnakenberg \& Tomlinson 2014). Mainonnaksi tunnistaminen on yksi tärkeä tekijä, jonka mukaan lukija arvioi sisältöä (Tutaj \& van Reijmersdal, 2012). Mainonnassa läpinäkyvyyttä on perinteisesti korostettu merkitsemällä se ilmoitukseksi tai muulla tavalla kaupalliseksi sisällöksi (Hoy \& Lwin 2007) myös Suomessa (Taiminen et al. tulossa). Lisäksi on ehdotettu, että kaupalliseksi sisällöksi merkitsemisessä pitäisi ottaa huomioon myös visuaaliset efektit, eli esimerkiksi miten hyvin se erottuu taustasta, onko se esillä tarpeeksi usein, ja ovatko tekstin koko ja muotoilu riittävän selkeitä (Hoy \& Lwin 2007). Toisaalta myös sisällön maksajan ja tuottajan esilletuonti voivat vaikuttaa koettuun läpinäkyvyyteen (Nelson et al. 2009; Cole \& Greer 2013; Miller \& Sinclair 2009), ja myös tekstin kirjoittajan esilletuonnilla saattaa olla merkitystä (Taiminen et al. tulossa).

Karlsson (2010) ehdottaa journalistisen sisällön läpinäkyvyyteen liittyen, että taustojen, näkökulmien ja työskentelytapojen esiin tuominen on tärkeä osa läpinäkyvää sisällöntuotantoa. Koska natiivimainonta journalistisessa mediassa pyrkii olemaan yhtenevää alkuperäisen sisällön kanssa, myös kirjoittajaan, tilaajaan, tuottajaan ja maksajaan liittyvät aspektit tulisi huomioida. Esimerkiksi median ohjeistukset natiivimainonnan prosessille ja brändin ja median roolit natiivimainonnassa on hyvä tuoda esille (Taiminen et al. tulossa).

Kuitenkin on ehdotettu, että läpinäkyvyyttä tulisi arvioida myös esitettyyn sisältöön ja sen sanavalintoihin liittyen (Carroll \& Einwiller 2014; Schnackenberg \& Tomlinson 2014). Plaisancen $(2007,187)$ mukaan läpinäkyvyyttä on myös se, miten me puhumme jostakin asiasta. Tälle informaation olennaisuudelle on ehdotettu useita eri ulottuvuuksia. Esimerkiksi Rawlins (2009) ja Schnakenberg \& Tomlinson (2014) laskevat läpinäkyvään viestintään kuuluvaksi informaation relevanttiuden, tarkkuuden, oikea-aikaisuuden, uskottavuuden ja ymmärrettävyyden. Toisaalta myös virheellisen sisällön korjaaminen ja siitä ilmoittaminen, tasapuolisen sisällön esittäminen ja mahdollisuuksien mukaan alkuperäislähteiden identifiointi sisällössä sekä subjektiivisten mielipiteiden selkeä esilletuonti on nähty tärkeinä läpinäkyvyyden kannalta erityisesti journalismissa (Karlsson 2010). Tärkeää onkin arvioida sitä, miten sisällön avulla pystytään selkeyttämään tai jopa parantamaan lukijoiden kokemaa läpinäkyvyyttä. Schnackenberg \& Tomlinson (2014) esittävät läpinäkyvyyden käyvän ilmi nimenomaan sisällön laadukkuutena.

Kuten jo edellä on todettu, sidosryhmien osallistamisella läpinäkyvyyden tuottamiseen on organisaatioviestinnän teoriassa keskeinen rooli. Vaikka läpinäkyvä viestintä perustuu monesti omaan tiedon jakamiseen sidosryhmien tiedontarpeiden pohjalta (Rawlins 2009; Baker 2008), läpinäkyvyysprosesseja voi tukea myös 
muulla tavalla. Läpinäkyvyyden mahdollistamista on myös luoda lukijoille mahdollisuuksia reagoida kuluttamaansa sisältöön (Bandsuch et al. 2008, 111). Tältä kannalta lukijoiden osallistaminen (engagement) ja voimaannuttaminen (empowerment) ovat tärkeä osa aidosti läpinäkyvää viestintää. Sidosryhmien osallistaminen prosessiin voi lisätä läpinäkyvyyttä myös mahdollistamalla suoran palautteen medialle (Shen \& Kim 2012) tai mahdollistamalla lukijoiden suoran vaikuttamisen sisällön kanssa esimerkiksi kommentointimahdollisuuksien muodossa (Karlsson 2010; Bandsuch et al. 2008), jolloin lukijat voivat arvioida kollektiivisesti sisällön läpinäkyvyyttä ja oikeellisuutta.

\section{Soveltaminen käytäntöön}

\section{Organisaation viestintä vaikuttaa} suoraan sen uskottavuuteen (Verčič, Verčič \& Laco 2008) ja luottamukseen (Rawlins 2009). Jotta varmistetaan aito uskottava viestintä, toimenpiteitä läpinäkyvyyden takaamiseksi pitäisi tarkastella kontekstisidonnaisesti (Taiminen et al. tulossa; Schnakenberg \& Tomlinson 2014). Natiivimainontaan liittyen, läpinäkyvyyttä pitäisikin peilata omiin ammattinormeihin ja vastuisiin - niihin odotuksiin, joita sidosryhmillä on ammattiryhmää kohtaan - sekä mainonnan ja mainostajan identifioimiseen ja sisällön laatukriteereihin. Perussääntönä läpinäkyvyyttä voi arvioida sen mukaisesti, parantaako jokin tietty elementti olennaisesti lukijakokemusta ja koettua läpinäkyvyyttä ja edesauttaako se lukijan ymmärrystä. On myös hyvä huomata, että informaatio- tulvan kautta liika monimutkaisuus voi itse asiassa jopa vähentää läpinäkyvyyttä (Baker 2008; Rawlins 2009).

Tältä osin läpinäkyvyys voidaankin nähdä suunnitelmallisena toimintana, sillä niin brändien kuin mediankin tulisi proaktiivisesti tunnustella ja sitä kautta varmistaa läpinäkyvä viestintä. Tältä kannalta läpinäkyvyys liittyykin organisaation kykyyn viestiä systemaattisesti omaan identiteettiinsä, osaamiseensa ja toimintaansa perustuen (Gilpin et al. 2010; Shen \& Kim 2012). Samalla tulee kunnioittaa sidosryhmien tarpeita (Rawlins 2009; Albu \& Wehmeier 2014) ja mahdollistaa sidosryhmien kuuleminen ja osallistuminen läpinäkyvyyden vaateiden täyttämiseen (Rawlins 2009; Gilpin et al. 2010; Baker 2008). Käytännössä natiivimainonnan ja sponsoroidun sisällön tapauksessa viestinnän ammattilaisten kannattaa arvioida natiivimainonnan tai sponsoroidun sisällön läpinäkyvyyttä vähintäänkin seuraavat tekijät ja kysymykset huomioon ottaen:

1) Vastaako läpinäkyvyys niihin odotuksiin, joita natiivimainonnan toteuttajalta odotetaan?

Vähimmäisvaatimuksena viestinnän ja median ammattilaisille on toimia alan itsesääntelyn ja lakien mukaisesti. Eettiseltä kannalta ajatellen lähtökohtana natiivimainonnalle ovat brändien ja median omat vastuut ja toimijoiden integriteetti. Tästä syystä median on mietittävä, uhkaako natiivimainonta mediatoimijoiden integriteettiä ja omavaltaisuutta. Vähentääkö se esimerkiksi median uskottavuutta 
tai uhkaako se journalistien neutraaliutta? Toisaalta brändien tulisi miettiä muun muassa sitä, missä määrin heidän viestintänsä perustuu totuudenmukaisuuteen ja sosiaaliseen vastuuseen ja voidaanko olla varmoja, että mainonta kunnioittaa lukijoita (Baker \& Martinson 2001). Sidosryhmien odotuksien ja ammattinormien peilaaminen läpinäkyvyyden turvaamiseksi on siis tärkeää, mutta näiden tekijöiden ymmärtäminen muodostuu läpinäkyvyydeksi vasta, kun vastuut viestitään osana natiivimainontaa esimerkiksi ohjeistuksien muodossa, jotka ovat löydettävissä.

\section{2) Saavathan sidosryhmät osallistua} sisältöösi ja itse läpinäkyvyysprosessiin?

Läpinäkyvä viestintä vaatii lukijoiden ymmärryksen edesauttamista (Rawlins 2009). Ajan kuluessa lukijat oppivat ymmärtämään uusia mainonnan tapoja ja samalla muodostavat odotuksia niiden läpinäkyvyydestä. Tällä hetkellä ei voida kuitenkaan olettaa, että lukijat ovat välttämättä perillä natiivimainonnan trendeistä (Tutaj \& van Reijmersdal 2012). Tästä syystä sidosryhmän tarpeet ja olennaiset viestittävät tekijät läpinäkyvyyden takaamiseksi on syytä selvittää yhdessä sidosryhmien kanssa - pelkkä median tai brändien viestinnän läpinäkyvyyden itsearviointi ei siis riitä. Tästä huolimatta organisaatioiden tulisi ymmärtää ja arvioida omat läpinäkyvyyden pyrkimyksensä ja toimintatapansa ja verrata niitä sidosryhmien mielipiteisiin.

\section{3) Tuodaanko natiivimainonnassa selvästi esiin taustat ja kaupalliset intressit?}

Vaikka kaiken informaation esilletuominen ei ole läpinäkyvyyden itseisarvo (Rawlins 2009), sidosryhmien tarpeisiin perustuva kaupallisen sisällön visuaalinen merkitseminen on keskeistä läpinäkyvyyden takaamiseksi. Kuten muidenkin mainonnan muotojen kohdalla, myös natiivimainonnan ja sponsoroidun sisällön tulee olla helposti identifioitavissa kaupalliseksi sisällöksi ja merkintätavan tulee olla selvästi ymmärrettävissä maksetuksi sisällöksi. Suomessa monesti merkintätavat ovatkin vaihdelleet 'ilmoitus', 'mainos', 'yhteistyössä' tai 'sponsoroitu' merkintöjen välillä.

Sisällön maksajan, tuottajan ja kirjoittajan asettaminen aina tarkempiin median ja brändien sisällöntuotannon rooleihin voi myös edesauttaa natiivimainonnan läpinäkyvyyttä. Tällöin yhdessä kaupalliseksi sisällöksi merkitsemisen kanssa mahdollistetaan, ettei brändimainonta ole piilomainontaa. Läpinäkyvyyden korostamiseksi myös selkeä visuaalinen erottelu alkuperäisestä journalistisesta sisällöstä, esimerkiksi fonttien tai taustavärin muodossa, voi olla tarpeen. Yhdessä nämä tekijät muodostavat kokonaisuuden, joka mahdollistaa niin tietoisen kuin myös välittömän, tiedostamattomalla tasolla tapahtuvan eron tekemisen alkuperäisen sisällön kanssa.

\section{4) Onko sisältö läpinäkyvästi esitetty?}

Kuten aiemmin esitettiin, läpinäkyvyys ei 
liity pelkästään sen erottamiseen maksetuksi sisällöksi. Carroll \& Einwiller (2014) käyttävät termiä läpinäkyvyyden viestitys (transparency signalling) kuvaamaan tekijöitä, jotka korostavat kunkin sisällönosan aitoutta, avoimuutta ja läpinäkyväksi tekemistä. Sisällön voidaankin ajatella perustuvan läpinäkyvyyteen, jos seuraavat kriteerit täyttyvät (Rawlins 2009; Schnakenberg \& Tomlinson 2014):

\section{1) Tarkkuus ja uskottavuus: Nämä} tekijät liittyvät informaation esilletuonnin tapaan, jolloin läpinäkyvyys kuvastuu tekstissä pyrkimyksenä identifioida faktatiedot ja niiden lähteet ja erottaa ne subjektiivisesta tiedosta. Samalla selitetään peittelemättömästi, millaista tieto milloinkin on. Tämä siis lisää myös sisällön totuudenmukaisuutta. Myös virheiden avoin korjaaminen ja selittäminen liittyvät olennaisena osana uskottavaan informaation välittämiseen.

2) Selkeys ja ymmärrettävyys: Näitä tekijöitä korostaakseen natiivimainonnassa tulee käyttää kieltä, jonka lukija ymmärtää. Näin läpinäkyvyyttä voidaan edistää esimerkiksi vähentämällä tiedon monimutkaisuutta tai selittelyn määrää, jolloin informaation prosessointi helpottuu.

3) Relevanttius ja oikea-aikaisuus: Läpinäkyvyyden takaamisessa on syytä miettiä, mitkä tekijät ovat oleellisia. Turha tieto vähentää selkeyttä ja ymmärrettävyyttä infotulvan takia.
Oikea-aikaisuus taas takaa sen, ettei oleellista tietoa kerrota liian aikaisin tai liian myöhään, jolloin sen liittäminen alkuperäiseen argumenttiin voi olla hankalaa.

Näyttää siltä, että natiivimainonta ja sponsoroitu sisältö tulevat lisääntymään myös tulevaisuudessa (Business Intelligence 2015). Nativiimainontaa ovat alkaneet käyttää monet suuret mediatalot, kuten New York Times ja the Guardian. Suomessakin natiivimainontaan on valpastuttu, ja esimerkiksi JSN on perustanut työryhmän pohtimaan natiivimainonnan läpinäkyvyyttä (JSN 2015). Tulevaisuudessa natiivimainontaan kiinnitetään siis enenevässä määrin huomiota ja organisaatioiden ja brändien tulisi ymmärtää, että vaikka nämä brändätyn sisällön muodot perustuvat ärsyttämättömyyteen (Tutaj \& van Reijmersdal 2012), piilomainonnan ja advertoriaalien aikakausi on ohi. Kuvio 2 esittelee, miten maksettuja mediasisältöjä saadaan läpinäkyvämmäksi. Tavoitteena olisi saada kaikki yhteistyö median ja organisaation tai brändin välillä sopimaan vasemman yläkulman kuvailevaan ympäristöön, jolloin se voi olla sekä eettisesti kestävää, uskottavaa että läpinäkyvää. 


\section{0,130}

\section{Kuvio 2.}

Miten läpinäkyvyysviestintä vaikuttaa maksettujen mediasisältöjen uskottavuuteen.

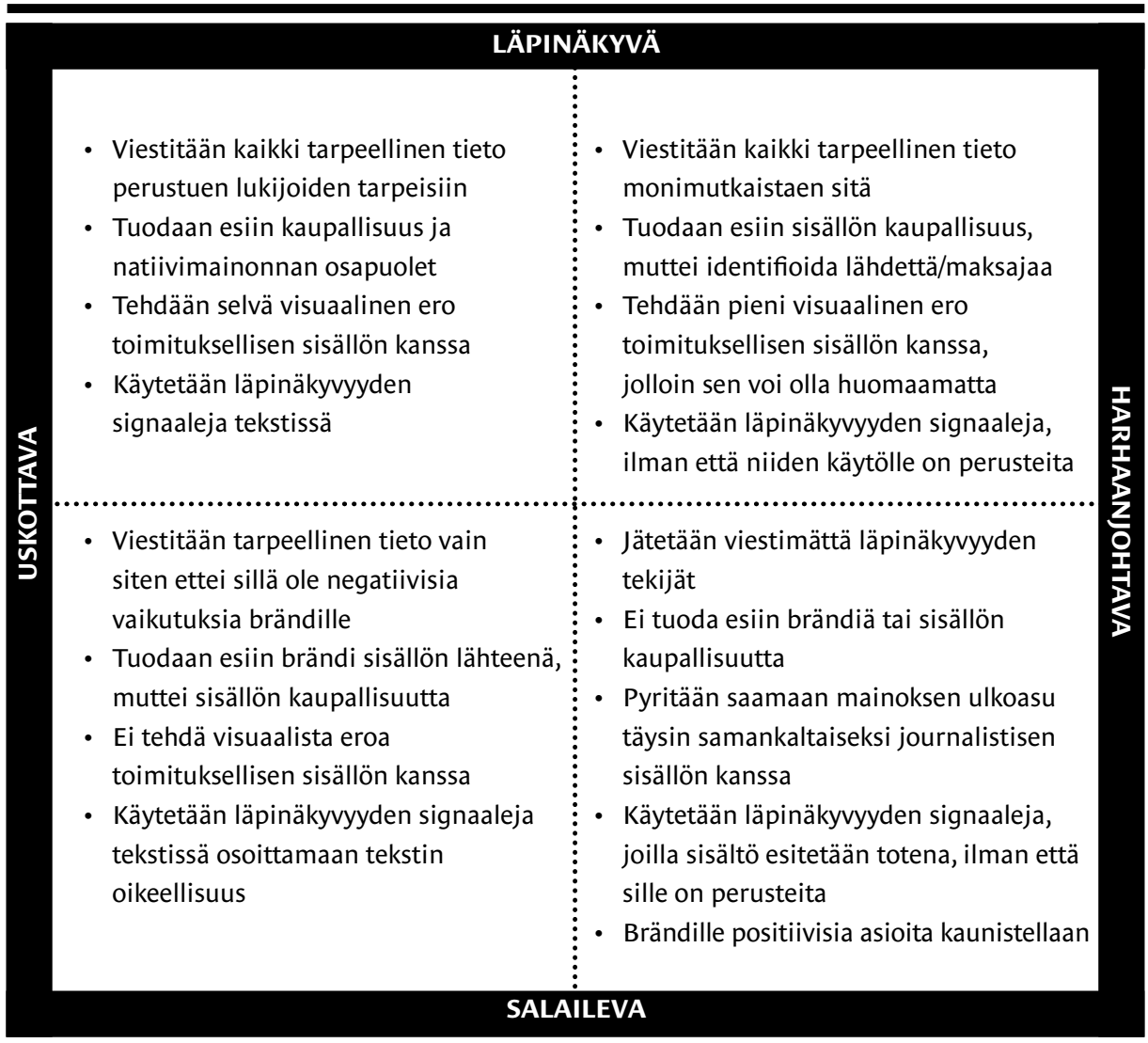

Natiivimainonnan ja sponsoroidun sisällön arvo kumpuaa organisaation esillä olemisesta ja aidosta asiantuntijuudesta viestityn asian alalla (IAB 2013a; Cole \& Greer 2013). Brändien ei siis pitäisi pelätä tuoda itseään esiin, sillä itse viestisisältöjen tai sisällön koetun suostuttelevuuden on todettu vaikuttavan maksetun sisällön sponsorilähdettä enemmän sisällön uskottavuuteen (Tutaj \& van Reijmersdal 2012). Sen sijaan laadukkaasti toteutettuna ja sidosryhmiä kunnioittamalla kyseiset maksetut mediasisällöt voivat jopa lisätä arvostusta ja yleistä hyväksyntää organisaatiota kohtaan, auttavat pitämään aktiviteetin uskottavana ja ylläpitävät niin median kuin natiivimainonnankin uskottavuutta. 


\section{Näistä voit aloittaa}

1) Taiminen, K., Luoma-aho, V. \& Tolvanen, K. (tulossa). Transparent Communicative Organization and Hybrid Content. Public Relations Review.

2) Rawlins, B. (2009). Give the emperor a mirror: Toward developing a stake holder measurement of organizational transparency. Journal of Public Relations Research, 21(1), 71-99.

3) Interactive Advertising Bureau (2015). Content \& Native Disclosure Guidan ce. URL: http://www.iabuk.net/sites/ default/files/Disclosure\%20Guidelines\%20on\%20Native\%20Distributi on\%20Formats\%202015.pdf.

\section{Lähteet}

Albu, O., \& Wehmeier, S. (2014). Organizational transparency and sense-making: The case of Northern Rock. Journal of Public Relations Research, 26(2), 117-133.

Baker, S. (2008). The model of the principled advocate and the pathological partisan: A virtue ethics construct of opposing archetypes of public relations and advertising practitioners. Journal of Mass Media Ethics, 23(3), 235-253.

Baker, S. \& Martinson, D. L. (2001). The TARES test: Five principles for ethical persuasion. Journal of Mass Media Ethics $16(2-3), 148-175$.

Bandsuch, M., Pate, L. \& Thies, J. (2008). Rebuilding Stakeholder Trust in Business: An Examination of Principle-Centered
Leadership and Organizational Transparency in Corporate Governance. Business and Society Review 113 (1), 99-127.

Bowen, S. A. (2004). Expansion of ethics as the tenth generic principle of public relations excellence: A Kantian theory and model for managing ethical issues. Journal of Public Relations Research 16 (1), 65-92.

Business Intelligence. 2015. Native Advertising Revenue (us). URL: https://twitter.com/BIIntelligence/status/530439845567819776

Carroll, C. E. \& Einwiller, S. A. (2014). Disclosure alignment and transparency signaling in CSR reporting. Hart, R. P. (Toim.):, Communication and Language Analysis in the Corporate World, 249-270). Hershey, PA: IGI-Global.

Cole, J. T. \& Greer, J. D. (2013). Audience response to brand journalism: The effect of frame, source, and involvement. Journalism and Mass Communication Quarterly, 90(4), 673-690.

Drumwright, M. E. \& Murphy, P. E. (2009). The current state of advertising ethics: Industry and academic perspectives. Journal of Advertising 38(1), 83-108.

Gilpin, D. R., Palazzolo, E. T. \& Brody, N. (2010). Socially mediated authenticity. Journal of Communication Management, 14(3), 258-278. 
Hoy, M. G. \& Lwin, M. O. (2007). Disclosures exposed: Banner ad disclosure adherence to FTC guidance in the top 100 US web sites. Journal of Consumer Affairs 41 (2), 285-325.

Interactive Advertising Bureau (2013a). Content marketing primer. Definition, Benefits, types and marketplace considerations for publishers, marketers and agencies. URL: http://www.iab.net/contentmarketing.

Interactive Advertising Bureau (2013b). Native advertising playbook. URL: $<$ http://www.iab.net/media/file/IAB-Native-Advertising-Playbook2.pdf>.

Julkisen sanan neuvosto. (2015). Työryhmä pohtii natiivimainontaa. URL: http:// www.jsn.fi/uutiset/tyoryhma-pohtii-natiivimainontaa/.

Kaler, J. (2000). Reasons to be ethical: Self-interest and ethical business. Journal of Business Ethics, 27(1/2), 161-173.

Karlsson, M. (2010). Rituals of transparency. Journalism Studies, 11(4), 535-545.

Luoma-aho, V. \& Taiminen, K. (2014). Mitä on tuotettu sisältö? Esitys Journalismin Päivässä 17.10.2014. Journalistiliitto. URL: https://prezi.com/jwuryns1dmpy/journalismin-paiva/\#

Miller, B. \& Sinclair, J. (2009). Community stakeholder responses to advocacy advertising. Journal of Advertising, 38(2), 37-51.
Molleda, J. (2010). Authenticity and the construct's dimensions in public relations and communication research. Journal of Communication Management, 14(3), 223-236.

Moses, L. (2013). After Scientology Debacle, The Atlantic Tightens Native Ad Guidelines Sponsored content will become more prominent on the site. AdWeek. URL: http://www.adweek.com/news/ advertising-branding/after-scientology-debacle-atlantic-tightens-native-ad-guidelines-146890.

Nelson, M. R., Wood, M. L. \& Paek, H. (2009). Increased persuasion knowledge of video news releases: Audience beliefs about news and support for source disclosure. Journal of Mass Media Ethics 24 (4), 220-237.

Plaisance, P. (2000). The Concept of Media Accountability Reconsidered. Journal of Mass Media Ethics 15(4), 257-268.

Plaisance, P. (2007). Transparency: An assessment of the Kantian roots of a key element in media ethics practice. Journal of Mass Media Ethics, 22(2/3), 187-207.

Rawlins, B. (2009). Give the emperor a mirror: Toward developing a stakeholder measurement of organizational transparency. Journal of Public Relations Research, 21(1), 71-99.

Schnackenberg, A. K. \& Tomlinson, E. C. (2014). Organizational Transparency A 
New Perspective on Managing Trust in Organization-Stakeholder Relationships. Journal of Management, 1-27. (tulossa)

Sonderman, J. \& Tran, M. (2013). Understanding the rise of sponsored content. American Press Institute Whitepaper.

Shen, H. \& Kim, J. (2012). The authentic enterprise: Another buzz word, or a true driver of quality relationships? Journal of Public Relations Research, 24(4), 371-389.

Taiminen, K., Luoma-aho, V., \& Tolvanen, K. (tulossa). The Transparent Communicative Organization and New Hybrid Forms of Content. Public Relations Review.

Tomažic, T., Boras, D., Jurišic, J., \& Lesjak, D. (2014). Covert advertising as inadmissible presentation of information. Industrial Management and Data Systems, 114(1), 107-122.

Tutaj, K., \& van Reijmersdal, E. A. (2012). Effects of online advertising format and persuasion knowledge on audience reactions. Journal of Marketing Communications, 18(1), 5-18.

van Reijmersdal, E. A., Neijens, P. C. \& Smit, E. G. (2010). Customer magazines: Effects of commerciality on readers' reactions. Journal of Current Issues and Research in Advertising, 32(1), 59-67.

Verčič, T., Verčič, D. \& Laco, K. (2008). Comparing advertising and editorials: An experimental study in TV and print.
Public Relations Review, 34(4), 380-386.

Verčič, T., Verčič, D. \& Laco, K. (2008). Comparing advertising and editorials: An experimental study in TV and print. Public Relations Review, 34(4), 380-386. 
Tämä avoimuutta korostava näkemys asettuu vastakkain "suljetun innovaation" näkemyksen kanssa. Se korostaa innovaatioprosessia organisaation sisäisenä tuotekehitysprosessina, jota valmistellaan salassa ja johon osallistuvat vain organisaation omat tutkijat tai asiantuntijat. Organisaation viestinnällä voi olla merkittävä vaikutus avoimen vuorovaikutuksen mahdollistajana organisaation ja sidosryhmien välillä.

\section{Avoimuuden uusi tuleminen}

Avoimuus (openness) on maailmanlaajuinen trendi, joka haastaa suljettujen ovien päätöksentekokulttuuria, organisaatioiden yrityksiä toimia salassa ympäröivältä yhteiskunnalta sekä tiedon vapaata liikkuvuutta rajoittavia käytäntöjä, kuten akateemisen julkaisemisen maksumuurit. Läpinäkyvyydestä (transparency), jota avoimuuden avulla voidaan tavoitella, povataan myös vahvaa asetta organisaatioille kilpailuedun tavoittelussa esimerkiksi markkinoinnissa (Laakso, 2015).

Liiketoiminnan parissa tietoa on ollut perinteisesti tapana pantata viimeiseen asti, etteivät muut - esimerkiksi kilpailijat - saa käsiinsä samaa tietoa. Verkottuneessa, tietoperusteisessa taloudessa tiedon jakamisesta voi kuitenkin olla enemmän hyötyä kuin sen salaamisesta. Avoimuus edistää uusien palvelujen ja tuotteiden kehittämistä sekä prosessien tehostamista (esim. Gurin 2014), ja tätä kautta sillä on yhteys innovatiivisuuteen. Esimerkiksi organisaatioiden keräämän ja tuottaman avoimen datan (open data) on esitetty edistävän innovatiivisuutta (Poikola, Kola \& Hintikka 2010).

Tässä artikkelissa pyritään vastaamaan kysymykseen siitä, kuinka avoimuus kytkeytyy organisaation innovatiivisuuteen. Edistääkö avoin toimintamalli innovatiivisuutta, ja millä tavalla tämä käytännössä tapahtuu? Toiseksi artikkelissa tarkastellaan organisaation viestinnän roolia, kun tavoitellaan avoimesta toimintamallista koituvaa innovaatio- tai läpinäkyvyyshyötyä. Esimerkkeinä esitellään avoimeen dataan liittyviä kokeiluja erilaisissa organisaatioissa. Avoin data on sellaista organisaation avoimeksi saattamaa tietoa, jota se on kerännyt oman toimintansa tuotteena ja jonka se haluaa julkistaa vapaasti muiden käyttöön. Avointa dataa voivat hyödyntää niin organisaation toiminnasta kiinnostuneet tutkijat kuin esimerkiksi liiketoimintaa datan pohjalta kehittävät yrittäjätkin.

Artikkelin rakenne etenee siten, että seuraavassa alaluvussa määritellään keskeiset käsitteet ja tarkastellaan käsitteellisellä tasolla, kuinka avoimuus ja läpinäkyvyys voisivat kytkeytyä organisaation innovatiivisuuteen. Tämän jälkeen esitellään kolme erilaista näkökulmaa avoimuuteen avoimen datan esimerkkien kautta. Niiden avulla pyritään erittelemään erilaisia lähestymistapoja siihen, kuinka avoimuus ja innovatiivisuus kytkeytyvät toisiinsa. Samalla pyritään tuomaan esiin organisaation viestinnän näkökulmaa käytännön esimerkein. Lopuksi artikkelin keskeinen anti tiivistetään organisaation viestinnän näkökulmasta. 


\section{Avoimuus, läpinäkyvyys ja innovaatiot}

Mitä oikeastaan tarkoitetaan innovaatiolla ja innovatiivisuudella, ja miten nämä liittyvät avoimuuteen tai läpinäkyvyyteen?

Innovaatio on prosessi, jossa pyritään uudistamaan ja tehostamaan esimerkiksi organisaation toimintaa, prosesseja, tuotteita tai palveluita ottamalla käyttöön tai soveltamalla uusia toimintatapoja, -malleja tai tuotteita. Organisaation kyky olla innovatiivinen eli kehittää ja omaksua uusia innovaatioita on välttämätöntä sen selviytymisen ja toiminnan jatkuvuuden kannalta (March 1991). Innovaatio ei ole synonyymi esimerkiksi keksinnölle, vaan se kuvastaa sitä prosessia, jossa uusia ideoita tai toimintatapoja kehitetään ja pyritään viemään käytäntöön jossakin tietyssä kontekstissa.

Jos innovaatioprosessi nähtiinkin aiemmin organisaation sisäisenä tai sen kumppanien kesken toteutettavana, suljettuna kehitysprojektina, nyt innovaatioita koskeva kirjallisuus korostaa avoimuutta, organisaation rajojen läpäisevyyttä, tiedon ja osaamisen hajautunutta luonnetta sekä asiakkaiden, kumppanien ja muiden sidosryhmien panosta innovoinnissa (von Hippel 1986; Sawhney \& Prandelli 2000; Chesbrough 2003).

Organisaation innovaatio on monitasoinen ilmiö, johon vaikuttavat niin yksilö-, ryhmä-, kuin organisaatiotasonkin tekijät. Luoma-aho ym. (2012) ovat tutkineet organisaation innovatiivisuuteen vaikuttavia aineettomia tekijöitä ja jaotelleet ne kolmeen eri kategoriaan "arvotimanttimallin" avulla: timantin alimmalla (mikro-)tasolla ovat yksilöiden psykologiseen kantoky- kyyn ja joustavuuteen liittyvät tekijät. Keskimmäisellä (meso-)tasolla ovat tietotekniikan ketteryyteen sekä innovatiiviseen johtajuuteen, työvoiman diversiteettiin ja luottamukseen liittyvät tekijät. Ylimmällä (makro-)tasolla ovat yhteiskehittämiseen liittyvät tekijät, kuten yhteistyö asiakkaan ja brändin välillä. Avoimuuden voidaan nähdä kytkeytyvän paitsi yhteiskehittelyyn esimerkiksi organisaation ja sen sidosryhmien välillä, myös organisaation sisäiseen avoimuuteen, jonka edellytyksenä ovat luottamus ja instituution kyky tukea avointa vuorovaikutusta.

Yrityksen tai organisaation läpinäkyvyys määritellään perinteisesti sitä koskevan tiedon avoimeksi saatavuudeksi (esim. Bushman ym. 2004). Organisaatiota koskevan neutraalin informaation saataville asettamisen ja levittämisen uskotaan tekevän niistä läpinäkyvämpiä ja siten esimerkiksi vastuullisempia toimijoita. Läpinäkyvyyden vaateiden taustalla on sidosryhmien kasvanut kiinnostus organisaatioiden toimintaa kohtaan sekä niiden rooli osana ympäröivää yhteiskuntaa (esim. Christensen 2002).

Koska läpinäkyvyys ja avoimuus ovat molemmat yleisesti tavoiteltavia hyveitä organisaatioissa ja niiden viestinnässä sekä yhteiskunnassa laajemminkin, on syytä punnita, mikä näiden käsitteiden keskinäinen suhde on. Organisaatioviestinnän kirjallisuudessa lähdetään siitä, että läpinäkyvyyden edellytykset ja vaatimukset määritellään organisaation ja sen sidosryhmän välisessä vuorovaikutuksessa, eikä läpinäkyvyydelle siten ole olemassa mitään absoluuttista määritelmää (mm. 
Christensen 2002; Fombrun \& Rindova 2000). Läpinäkyvyys syntyy avoimuuden kautta mutta määrittyy organisaation ja sen sidosryhmien välisessä vuorovaikutuksessa.

Keskustelu läpinäkyvyydestä ja avoimuudesta kytkeytyy innovaatioihin: innovaatiota ei nähdä mahdollisena ilman jonkinasteista avoimuutta, joka on informaation ja ideoiden vaihdon edellytys. Mielikuva innovaation taustalla tutkijankammiossa yksin puurtavasta tutkijasta, suljettujen ovien takana toimivasta tuotekehitystiimistä tai yrityksen luovista osaajista on vanhentunut. Innovaatiot ovat ratkaisuja tosielämän konkreettisiin ongelmiin, ja ne syntyvät usean eri toimijan vuorovaikutteisessa ja monimutkaisessa prosessissa, jossa tarvitaan monenlaista tietoa ja osaamista - ja ennen kaikkea ehkä sellaista, jota organisaatiolla itsellään ei ole. Tässä mielessä erilaiset avoimuutta lisäävät strategiat voivat olla käyttökelpoisia myös innovatiivisuuden kannalta, ja kääntäen sama: tietojen avaaminen ja vuorovaikutus osana innovaatioprosessia ovat sidosryhmien osallistamista organisaation läpinäkyvyyden määrittelyyn.

Christensen ja Cheney (2015; myös Christensen 2002) ovat kritisoineet informaation jakamista korostavaa läpinäkyvyysmääritelmää turhan yksinkertaistavaksi. Heidän mukaansa määritelmässä ovat pielessä oletukset niin lähettäjästä, viestistä kuin vastaanottajastakin. Ensinnäkään lähettäjätaho eli organisaatio ei kykene itse näkemään sitä koskevaa informaatiota mitenkään objektiivisessa valossa ja täydellisesti - sen paremmin kuin kukaan muukaan. Toiseksi informaation merkitys ei ole vastaanottajasta riippumatonta. Kolmanneksi yleisö ei ole niin aktiivinen kuin läpinäkyvyyden puolestapuhujat ehkä olettavat.

Innovatiivisuuden näkökulmasta läpinäkyvyys ei ole siis vain "tiedon vaihtoa" avoimesti eri osapuolten välillä, vaan pikemminkin kyseessä on avoin toimintakulttuuri, avoimiin toimintatapoihin ja jakamiseen tähtäävä sosiaalinen normisto, jota määritellään jokaisessa vuorovaikutusteossa. Osittain tämän vuoksi suoraa yhteyttä läpinäkyvyyden ja avoimuuden vaikutuksesta innovaatioihin on vaikea vetää, sillä kyseessä on monimutkainen pitkän aikavälin prosessi, jossa on muitakin tekijöitä. Usein käytettyjä esimerkkejä tosin löytyy, joista kuuluisin lienee Piilaakso Yhdysvalloissa: alueen etikettiin kuuluu ideoiden ja omien projektien avoin jakaminen ja läpinäkyvyys, ja innovaatioita syntyy siellä vahvasti muita alueita enemmän. Organisaatioiden tasolla Suomessakin esimerkiksi julkishallinnon avaama data ja tietokannat ovat johtaneet monenlaisiin sovelluskehittäjäyhteisöjen tekemiin keksintöihin ja kokeiluihin, joista puolestaan on muodostunut innovaatioprosessin kautta kansalaisten arkea helpottavia palveluja, kuten reittioppaat ja sää- ja paikannuspalvelut. Samaan aikaan julkishallinto ja virastot ovat myös edistäneet mielikuvaa itsestään avoimena ja läpinäkyvänä toimijana.

\section{Ekosysteemi ja joukot}

Jos arkaluontoista informaatiota tai tietoja ei haluta paljastaa kilpailijalle, voidaan 
erilaisten kumppanuuksien ja verkostojen kautta pyrkiä saamaan etua "suljetun piirin" avoimuudesta. Tällöin ollaan kuitenkin tekemisissä hankalan rajanvedon kanssa sen suhteen, mikä määritellään avoimuudeksi tai läpinäkyvyydeksi.

Käytännössä jokin kumppaniverkosto voi toimia avoimesti siihen kuuluvien osapuolten välillä mutta olla samaan aikaan suljettu (ja ei siis läpinäkyvä) siihen kuulumattomille toimijoille. Parhaimmillaan tällaisten kumppanuuksien ympärille voi syntyä usean eri toimijan muodostamia innovaatioekosysteemejä, joissa eri toimijoiden "osainnovaatiot" yhdessä tuottavat jonkin palvelun tai ratkaisun kokonaisuuden (Adner 2006; Durst \& Poutanen 2013). Esimerkiksi monet teknologiset innovaatiot ovat tällaisia: jotta laajamittainen, käyttäjien tuottamien videoiden jakopalvelu olisi mahdollinen, tarvitaan yhtäaikaisesti mm. sen edellyttämä julkaisu- ja toistoteknologia, nopeaan tiedonsiirtoon kykenevät verkkoyhteydet sekä kehittyneitä mobiililaitteita ja -ohjelmistoja.

Avoimuus voi myös edistää käyttäjälähtöistä innovointia (von Hippel 1986), jossa asiakkaat tai loppukäyttäjät joko parantelevat käyttämäänsä palvelua tai tuotetta tai kehittävät kokonaan uuden ratkaisun. Von Hippelin tutkimukset innovoivista käyttäjäyhteisöistä osoittivat, kuinka innovaatio on itse asiassa hyvinkin sosiaalinen prosessi, jossa ei ole mielekästä piirtää selkeää rajaa "innovoivan tuottajan" ja "passiivisen loppukäyttäjän" välille. Käyttäjälähtöiseen innovointiin liittyy myös tuoreempana ilmiönä joukkoistaminen (crowdsourcing), jossa organisaatio avaa jonkin sen liiketoimintaa koskevan ongelman ja hakee loppukäyttäjistä tai muista kiinnostuneista ratkaisijoita joukkoistamisen mahdollistavien teknologioiden avulla. Käytännössä joukkoistaminen voi tapahtua esimerkiksi siihen erikoistuneen verkkopalvelun tai organisaation oman verkkopohjaisen sovellutuksen avulla.

Innovoinnin motiivina voi myös olla jonkin liiketoiminnan tai prosessin tehostaminen, esimerkiksi omaa kuluttaja- tai asiakasdataa hyödyntämällä. Tällöin puhutaan usein prosessi-innovaatiosta, jossa kerätään dataa omasta toiminnasta ja haetaan esimerkiksi kumppanien avulla ratkaisua omien tuotanto- tai toimitusprosessien tehostamiseen.

Taulukossa 1 on esitelty innovaatioprosessiin liittyvää käsitteistöä sekä niiden suhdetta avoimuuteen ja läpinäkyvyyteen.

\section{Taulukko 1.}

Avoimen innovaation muodot ja suhde läpinäkyvyyteen. 


\section{O, / 39}

\begin{tabular}{|c|c|c|}
\hline Käsite & Määritelmä & Suhde läpinäkyvyyteen \\
\hline Avoin innovaatio & $\begin{array}{l}\text { Käsitys ja toimintamalli, joka pai- } \\
\text { nottaa yhteistyön ja organisaation } \\
\text { ulkopuolisten toimijoiden ja } \\
\text { tiedon merkitystä osana innovaa- } \\
\text { tioprosessia. }\end{array}$ & $\begin{array}{l}\text { Avoin innovaatio ei ole mahdol- } \\
\text { linen ilman jonkinasteista läpi- } \\
\text { näkyvyyttä; avoimuuden edellytyk- } \\
\text { senä on organisaatiota koskevan } \\
\text { tiedon jakaminen ulkopuolisten } \\
\text { tahojen kanssa. }\end{array}$ \\
\hline $\begin{array}{l}\text { Innovaatio } \\
\text {-ekosysteemi }\end{array}$ & $\begin{array}{l}\text { Yhteistyöhön perustuva järjestely, } \\
\text { jossa useat toimijat yhdistävät } \\
\text { voimansa yhtenäisen tuote- tai } \\
\text { palveluratkaisun tuottamiseksi. }\end{array}$ & $\begin{array}{l}\text { Ekosysteemin sisällä tietoa ja } \\
\text { kokemuksia jaetaan avoimesti. } \\
\text { Ekosysteemin jäsenillä on yhteis- } \\
\text { ymmärrys yhteistyön hyödyistä. } \\
\text { Ekosysteemi voi olla läpinäky- } \\
\text { vyyden näkökulmasta "suljettu } \\
\text { systeemi" siihen kuulumattomille } \\
\text { toimijoille. }\end{array}$ \\
\hline $\begin{array}{l}\text { Käyttäjälähtöinen } \\
\text { innovointi }\end{array}$ & $\begin{array}{l}\text { Organisaation asiakkaan (b-to-c } \\
\text { / b-to-b) kehittelemä parannus } \\
\text { olemassa olevaan tuotteeseen tai } \\
\text { kokonaan uusi tuote, ratkaisu tai } \\
\text { tapa toimia. }\end{array}$ & $\begin{array}{l}\text { Organisaatio voi tavoitella innova- } \\
\text { tiivisuutta sitouttamalla ja kannus- } \\
\text { tamalla tuotteiden ja palveluiden- } \\
\text { sa käyttäjiä niiden kehittäjiksi ja } \\
\text { "asiantuntijoiksi". Tämä edellyttää } \\
\text { läpinäkyvyyttä sidosryhmien suun- } \\
\text { taan, jotta käyttäjien ja organisaa- } \\
\text { tion tarpeet kehittelyn suhteen } \\
\text { voivat kohdata. }\end{array}$ \\
\hline $\begin{array}{l}\text { Prosessi } \\
\text {-innovaatio }\end{array}$ & $\begin{array}{l}\text { Uuden tai merkittävällä tavalla } \\
\text { parannellun tuotanto- tai toimitus- } \\
\text { prosessin käyttöönotto. }\end{array}$ & $\begin{array}{l}\text { Organisaation tuotanto- ja } \\
\text { toimitusprosesseja voidaan avata } \\
\text { harkinnan mukaan esimerkiksi } \\
\text { jakamalla niitä koskevaa dataa. } \\
\text { Dataa voidaan jakaa organisaation } \\
\text { sidosryhmille toiminnan kehittä- } \\
\text { miseksi. }\end{array}$ \\
\hline
\end{tabular}




\section{Esimerkkejä avoimesta toimintamallista ja innovatiivisuuden edistämisestä}

Tähän mennessä artikkelissa on tarkasteltu erilaisten teoreettisten näkökulmien kautta sitä, miten avoimuus liittyy innovatiivisuuteen. Millä tavalla nämä lähestymistavat voivat käytännössä toteutua? Onko olemassa konkreettisia esimerkkejä? Entä mikä on viestinnän rooli avoimuutta hyödyntävässä innovoinnissa? Seuraavaksi käsitellään muutamia lähinnä avoimeen dataan liittyviä esimerkkejä, jotka kuvastavat organisaation yrityksiä toimia avoimemmin ja samaan aikaa tavoitella innovatiivisempaa toimintatapaa ja -kulttuuria. Lopuksi kootaan yhteen näiden tapausten antia viestinnän näkökulmasta.

\section{Päätöksentekoa ja toimintaa} kuvaavan tiedon avaaminen

Läpinäkyvyyttä pyritään lisäämään julkaisemalla organisaation toimintaa kuvaavia tietoja ja raportteja, saattamalla julkiseksi organisaation päätöksentekoa koskevia dokumentteja ja asiakirjoja sekä tuottamalla dataa ja tilastotietoa organisaation toiminnasta.

Yritysten kohdalla tällainen läpinäkyvyyden lisäämiseen pyrkivä tiedon levittäminen on ymmärretty perinteisesti erilaisten raporttien tuottamisena, kuten vastuullisuusraportit ja organisaation toimintaa, suunnitelmia ja taloudellista tilaa kuvaavat raportit ja selvitykset. Julkiset organisaatiot ovat puolestaan pyrkineet lisäämään läpinäkyvyyttään avoimella toimintamallilla, johon kuuluu muun muassa päätöksentekoa koskevien asiakirjojen julkaiseminen avoimesti.
Suomessa julkishallinnon toimintaa ohjaa julkisuuslainsäädäntö eli avoimuuden periaate, jonka mukaan tiedot ovat julkisia ellei lainsäädäntö niitä rajoita, ja lisäksi julkinen tieto on käytettävissä kaupallisiin ja ei-kaupallisiin tarkoituksiin (Kauhanen-Simanainen 2015). Käytännössä julkiset organisaatiot voivat viedä päätöksentekoa tai päätöksentekoprosesseja koskevia dokumentteja verkkoon avoimesti saataville PDF-muodossa tai siten, että niitä pääsee lukemaan automatisoidusti tietokoneohjelman avulla, ilman erillistä lupaprosessia. Tällä tavalla kiinnostuneet tahot voivat analysoida päätöksentekoprosesseja tai rakentaa tietokonesovellutuksia, joiden avulla voi analysoida esimerkiksi sitä, mitä tahoja, kuinka usein ja missä roolissa eri prosesseihin on osallistunut.

Tällaisen organisaation valitsemaa tietoa jakavan ja avoimeksi tekevän toimintamallin taustalla on ajatus siitä, että objektiivisessa muodossa esitetyn informaation tarjoaminen organisaation toiminnasta tekee siitä läpinäkyvämmän. On syytä huomata, että minkä tahansa tiedon tai datan avaaminen ei kuitenkaan automaattisesti lisää läpinäkyvyyttä. Esimerkiksi reitti- ja sääoppaat tai ajoneuvorekisteritietoa hyödyntävät palvelut ovat kyllä viranomaisten avaamaa tietoa ja niiden pohjalta kehitetyt innovatiiviset sovellusratkaisut helpottavat ihmisten arkea, mutta eivät ne sinällään lisää hallinnon läpinäkyvyyttä. Vastuullisuusraportointi voidaan puolestaan nähdä organisaation tuottamana tietona ja näkökulmana sellaisiin kysymyksiin, joista niiltä odotetaan avoimuutta, kuten tuotantoketjun eri 
toimijoiden eettisyys tai ympäristöasiat.

\section{Avoimen toimintakulttuurin edistäminen}

Läpinäkyvyyteen tähtäävä projekti on aina viesti itsessään. Se välittää organisaatiosta tietynlaista kuvaa: millaista profiilia ja arvoja organisaatio haluaa vahvistaa lisäämällä avoimuutta, esimerkiksi avaamalla joitain tietoaineistoja tai tuottamalla toimintaansa kuvaavia raportteja? Millaista tarinaa avoimuuden lisääminen tekona ja toimintana kertoo organisaatiosta? Entä mitä siitä seuraa?

Jos avoimuuden lisäämistä lähestytään puhtaasti organisaatioidentiteetin kautta, voidaan kysyä, miten esimerkiksi datan tai raporttien julkaisemisesta tulisi viestiä. Christensen (2002) on lähestynyt läpinäkyvyyttä strategisena valintana sen suhteen, mitä tietoja organisaatio haluaa tuottaa ja esittää avoimesti sidosryhmille, kuinka tämä tieto viestitään ja miten sitä koskevat merkitykset muodostuvat. Avoimuus on paitsi viesti läpinäkyvyydestä, myös "kutsu" sidosryhmille määrittelemään organisaatiota ja sen identiteettiä. Esimerkiksi vastuullisuusraportointi voi olla tehokas tapa rakentaa läpinäkyvyyttä suhteessa organisaation toimintaa seuraavaan järjestöön, kun taas tietojen julkaiseminen koskien organisaation päätöksentekoa voi olla laajemmalle kohdeyleisölle suunnattu viesti avoimesta toimintakulttuurista. Raporttien ja tietojen sisältö on vähintäänkin yhtä tärkeää kuin yhteydenpito itsessään.

Ehkä selkein linkki organisaation innovatiivisuuden ja avoimuuden välille syntyy avoimen datan hankkeiden kautta. Ne ovat paitsi itsessään innovatiivisuutta edistäviä toimintamalleja, myös viestejä avoimesta ja edistyksellisestä toimintakulttuurista: olemme avoimia edelläkävijöitä ja toimintamme on läpinäkyvää. Esimerkiksi Helsingin kaupunki on oman verkossa olevan Helsinki Region Infoshare -datakatalogin kautta profiloitunut Suomen mittapuussa edelläkävijäkaupungiksi, joka panostaa tietoaineistojen avaamiseen ja yhteiskehittelyyn eri tahojen kanssa. Tämä on tärkeä viesti mielikuvatasolla esimerkiksi yrittäjille, jotka harkitsevat perustavansa liiketoimintaa avoimen datan ympärille. Samaa mielikuvaa tavoittelevat varmasti myös muut suuret kaupungit 6aika-hankkeella, jossa rakennetaan koko Suomen kattavaa yritysten ja kumppanien verkostoja kaupunkien datojen hyödyntämiseksi ja avaamiseksi sekä uuden liiketoiminnan synnyttämiseksi.

\section{Käyttäjäyhteisöjen aktivointi avoimeen yhteistyöhön}

Kolmanneksi avoimuuden lisäämistä voidaan lähestyä käytännölliseltä kannalta sidosryhmien aktivoinnin näkökulmasta: kuinka auttaa eri osapuolia kohtaamaan ja saada heidät osallistumaan organisaation kanssa avoimeen innovointiin?

Poikola, Kola ja Hintikka (2010) ovat tutkineet datan avaamisen vaikutuksia organisaation innovatiivisuudelle. He huomauttavat, että datan avaamiseen liittyvät hankkeet eivät ole luonteeltaan "teknisiä projekteja", vaan ne on syytä rakentaa keskeisten sidosryhmien ympärille: ketkä käyttävät, hyödyntävät ja jalostavat 
dataa? Heidän mukaansa datan käyttäjät ja ohjelmoijat ovat parhaita asiantuntijoita siinä, miten dataa pitäisi tarjota, joten heitä on syytä hyödyntää datan avaamisen prosessissa. Lisäksi on syytä pitää huolta siitä, että data on ylipäätään löydettävissä, ja tässä kohtaa siitä viestiminen on keskeisellä sijalla. Ensimmäisen sovelluksen saama näkyvyys tuo lisää näkyvyyttä myös datalle ja sen tarjoajalle, sekä parhaassa tapauksessa houkuttaa paikalle lisää kehittäjiä (emt, 27).

Poikolan ym. $(2010,28)$ mukaan luontevin tapa hakea datan avaamiselle näkyvyyttä ja löytää kiinnostuneita kumppaneita on jalkautua sosiaalisen median pariin. Hyviä tapoja ovat myös erilaiset kilpailut ja yhteishankkeet, joista tuoreena esimerkkinä aiemmin mainittu kuuden suuren suomalaisen kaupungin avoin data -hanke. Tällainen hanke tukee sekä yhteistyötä eri toimijoiden välillä että rakentaa avoimuuden kulttuuria kaupunkien ja yrittäjien välillä.

Yritysorganisaatioiden osalta esimerkit kuvaavat usein "suljetumpaa avoimuutta", jossa hyödynnetään ja jaetaan esimerkiksi käyttäjien tuottamaa ja jakamaa tietoa ja dataa koskien yrityksen tuotteita tai palveluita. Esimerkiksi suomalainen Foodie.fm on personoitu osto- ja ruokasuosituspalvelu, joka hyödyntää käyttäjiltä keräämäänsä dataa, jota puolestaan tuotetaan ja hyödynnetään yhteistyössä ruokaketjujen kanssa. Tällöin kuluttajat jakavat "avoimesti" omaa dataansa palveluntarjoajille, jotka puolestaan vastaavat tuottamalla paremmin räätälöityjä palveluja asiakkailleen. Keskustelua kansalaisten ja kulutta- jien oikeudesta "oma dataan" (my data) sekä siitä syntyvistä julkisista ja kaupallisista palveluista onkin käyty vilkkaasti (esim. Poikola, Kuikkaniemi \& Kuittinen 2014).

\section{Lopuksi: organisaation viestintä avoimessa innovoinnissa}

Nämä esimerkit tuovat esiin erilaisia näkökulmia siihen, kuinka avoimuutta ja innovatiivisuutta voidaan tavoitella samanaikaisesti ja niiden tukiessa toisiaan. Avoimuuden kulttuuria voi rakentaa palasissa, sitä edistävillä hankkeilla sekä niistä viestimisellä. Tällöin organisaatiot luovat uusia yhteistyömahdollisuuksia avoimuuden hengessä perustamalla esimerkiksi oman toiminnan (sivu)tuotoksena syntyvää dataa jakavan verkkokatalogin ja kutsumalla kumppaneita yhteiskehitysprojekteihin. Näin organisaatio paitsi tarjoaa konkreettisen tarttumapinnan yhteistyölle, se myös tarjoaa itsestään kokemuksen avoimena toimijana. Kysymykseksi nouseekin, kuinka houkutella innostuneita ja motivoituneita kumppaneita toimimaan yhteistyössä organisaation kanssa?

Taulukkoon 2 on koottu eri näkökulmat avoimeen innovointiin erittelemällä mahdollisia sidosryhmiä, tavoitteita sekä viestinnän keinoja. 


\section{O, I 43}

\section{Taulukko 2.}

Näkökulmat avoimeen innovointiin.

\begin{tabular}{|c|c|c|c|c|}
\hline Näkökulma & Kohderyhmä & $\begin{array}{l}\text { Strateginen } \\
\text { tavoite }\end{array}$ & $\begin{array}{l}\text { Esimerkkejä } \\
\text { keinoista }\end{array}$ & $\begin{array}{l}\text { Viestinnän } \\
\text { rooli }\end{array}$ \\
\hline
\end{tabular}

\begin{tabular}{|c|c|c|c|c|}
\hline $\begin{array}{l}\text { Päätöksen- } \\
\text { tekoa ja } \\
\text { toimintaa } \\
\text { kuvaavan } \\
\text { tiedon } \\
\text { avaaminen }\end{array}$ & $\begin{array}{l}\text { Media, asiakkaat, } \\
\text { organisaation } \\
\text { toiminnasta kiin- } \\
\text { nostuneet } \\
\text { vaikuttajayhteisöt }\end{array}$ & $\begin{array}{l}\text { Läpinäkyvyyden } \\
\text { lisääminen }\end{array}$ & $\begin{array}{l}\text { Päätöksenteko- } \\
\text { prosessien, toiminta- } \\
\text { tapojen, kumppa- } \\
\text { nuuksien yms. } \\
\text { avaaminen; } \\
\text { toimintaa koskevien } \\
\text { tietojen julkaisemi- } \\
\text { nen ja saattaminen } \\
\text { avoimesti saataville. } \\
\text { Vastuullisuusraportit } \\
\text { ja selvitykset. }\end{array}$ & $\begin{array}{l}\text { Informaation levittäjä } \\
\text { ja siirtäjä, infor- } \\
\text { maation esillepano; } \\
\text { organisaatiota koske- } \\
\text { vien "tietoaukkojen" } \\
\text { paikkaaminen. }\end{array}$ \\
\hline $\begin{array}{l}\text { Avoimuuden } \\
\text { kulttuurin } \\
\text { edistäminen }\end{array}$ & $\begin{array}{l}\text { Media, asiakkaat, } \\
\text { organisaation } \\
\text { toiminnasta kiin- } \\
\text { nostuneet } \\
\text { vaikuttajayhteisöt }\end{array}$ & $\begin{array}{l}\text { Kokemuksien } \\
\text { tarjoaminen } \\
\text { sidosryhmille } \\
\text { avoimesti } \\
\text { toimivasta } \\
\text { organisaatiosta }\end{array}$ & $\begin{array}{l}\text { Avoimuudesta } \\
\text { kertovat kampanjat } \\
\text { ja markkinointi; } \\
\text { avoimuutta edistävät } \\
\text { projektit (esim. avoin } \\
\text { data, raportit). }\end{array}$ & $\begin{array}{l}\text { Organisaatiota kos- } \\
\text { kevien kokemusten } \\
\text { tarjoaminen ja raken- } \\
\text { taminen vuorovaiku- } \\
\text { tuksessa sidosryhmien } \\
\text { kanssa. }\end{array}$ \\
\hline $\begin{array}{l}\text { Käyttäjä- } \\
\text { yhteisöjen } \\
\text { aktivointi }\end{array}$ & $\begin{array}{l}\text { Kumppanit, } \\
\text { asiakkaat, } \\
\text { kehittäjäyhteisöt, } \\
\text { verkostot }\end{array}$ & 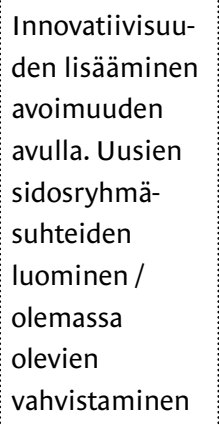 & $\begin{array}{l}\text { Tiedon jakaminen } \\
\text { avoimesti, datan } \\
\text { avaaminen, yhteis- } \\
\text { kehittely. } \\
\text { Kiinnostuneiden } \\
\text { kumppanien paikan- } \\
\text { taminen ja osallista- } \\
\text { minen esimerkiksi } \\
\text { sosiaalista mediaa } \\
\text { hyödyntämällä. }\end{array}$ & $\begin{array}{l}\text { Organisaation tarpeen } \\
\text { tunnetuksi tekeminen, } \\
\text { kohderyhmien tavoit- } \\
\text { taminen, innostami- } \\
\text { nen osallistumaan, } \\
\text { sitouttaminen organi- } \\
\text { saation toimintaan / } \\
\text { tavoitteisiin. }\end{array}$ \\
\hline
\end{tabular}




\section{0,144}

Viestinnän näkökulmasta keskeistä on ensinnäkin se, mitä avoimuudella tavoitellaan, kenelle avattavaksi tarkoitettava tieto, raportti, dokumentti, asiakirja tai data on suunnattu ja millaisin keinoin avoimuutta konkreettisesti edistetään. Toiseksi viestinnässä korostuu se, millaista kokemusta organisaatiosta avoimuuden toimenpiteet luovat suhteessa eri sidosryhmiin. Kolmanneksi viestintä voi toimia innovaatioihin tähtäävän datan avaamisen prosessin tukena esimerkiksi pyrkimällä paikantamaan, innostamaan, osallistamaan ja sitouttamaan potentiaalisia kehittäjäyhteisöjä. Alla oleva kuvio jäsentää, miten viestintä vaikuttaa organisaation läpinäkyvyyteen.
Se, onnistuuko viestintä rakentamaan läpinäkyvän organisaation, on usein myös resurssi- ja yhteistyökysymys. Viestinnän tulee toimia avoimessa yhteistyössä eri sidosryhmien lisäksi koko organisaation muiden yksiköiden ja osaajien kanssa. Pelkällä viestinnällä ei saavuteta läpinäkyvyyttä eikä innovaatioitakaan, mutta viestinnän ammattilaisilla on mahdollisuus ottaa organisaatioissa avoimuusjohtajan rooli niiden rakentamisessa. Avoimuuden ja läpinäkyvyyden aikakaudella on vain ajan kysymys, kun joku tuon roolin ottaa.

\section{Lähteet}

Adner, R. (2006). Match your innovation strategy to your innovation ecosystem.

Viestinnän rooli

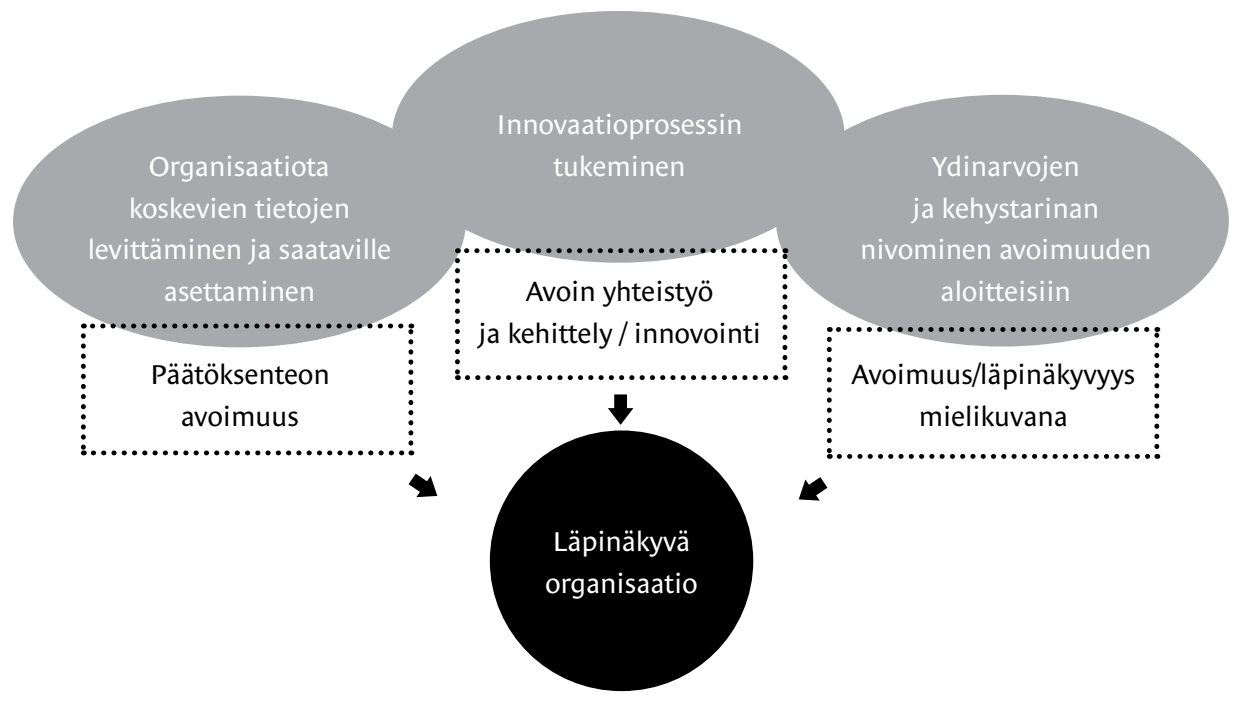


Harvard Business Review Vol. 84, 98-110. Bushman, R. M., Piotroski, J. D. \& Smith, A. J. (2004). What determines corporate transparency? Journal of accounting research (42)2, 207-252.

Chesbrough, H.W. (2003). Open Innovation: The New Imperative for Creating and Profiting from Technology. Harvard Business School Press, Boston, MA, Boston, Massachusetts.

Christensen, L. T. (2002). Corporate communication: The challenge of transparency. Corporate Communications: An International Journal, 7, 162-168.

Durst, S., \& Poutanen, P. (2013). Success factors of innovation ecosystems: A literature review. Smeds, R. \& Irrmann, O. (toim.) CO-CREATE 2013: The Boundary-Crossing Conference on Co-Design in Innovation, 27-38. Aalto University Publication series SCIENCE + TECHNOLOGY 15/2013.

Fombrun, C. J. \& Rindova, V. P. (2000). The road to transparency: Reputation management at Royal Dutch/Shell. The expressive organization, 7, 7-96.

Gurin, J. (2014). Driving Innovation With Open Data, Teoksessa The Future of Data-Driven Innovation (pp. 54-65.). U.S. Chamber of Commerce Foundation. http:// www.uschamberfoundation.org/driving-innovation-open-data

Kauhanen-Simanainen, A. (2015). Avoimen tiedon ohjelma - ajankohtaiskatsaus tiedon avaamiseen Suomessa. Esitelmä Avoin tieto ja tilastotoimi -seminaarissa 5.2.2015. http://www.slideshare.net/Tilastokeskus/ avoimen-tiedon-ohjelma-ajankohtaiskatsaus-tiedon-avaamiseen-suomessa

Laakso, H. (2015). 2-0-1-5. MTL-blogi. 23.4.2015. http://mtl.fi/fi/ala/blogi/2-0-1-5

Luoma-aho, V., Vos, M., Lappalainen, R., Lämsä, A. M., Uusitalo, O., Maaranen, P., \& Koski, A. (2012). Added value of intangibles for organizational innovation. Human Technology 8(1), 7-23.

March, J. G. (1991). Exploration and expolitation in organizational learning. Organization Science 2(1), 71-87.

Poikola, A., Kuikkaniemi, K. \& Kuittinen, O. (2014). My data - johdatus ihmiskeskeiseen henkilötiedon hyödyntämiseen. Liikenne- ja viestintäministeriön selvitys. http://urn.fi/URN:ISBN:978-952-243-418-0

Poikola, A., Kola, P. \& Hintikka, K. A. (2010). Julkinen data - johdatus tietovarantojen avaamiseen. Liikenne- ja viestintäministeriön julkaisu. http://urn.fi/ URN:ISBN:978-952-243-146-2

Sawhney, M. \& Prandelli, E. (2000). Communities of Creation: Managing Distributed Innovation in Turbulent Markets. California Management Review 42(4), 24-54.

von Hippel, E. (1986). Lead Users: A Source of Novel Product Concepts. Management Science 32(7), 791-805. 


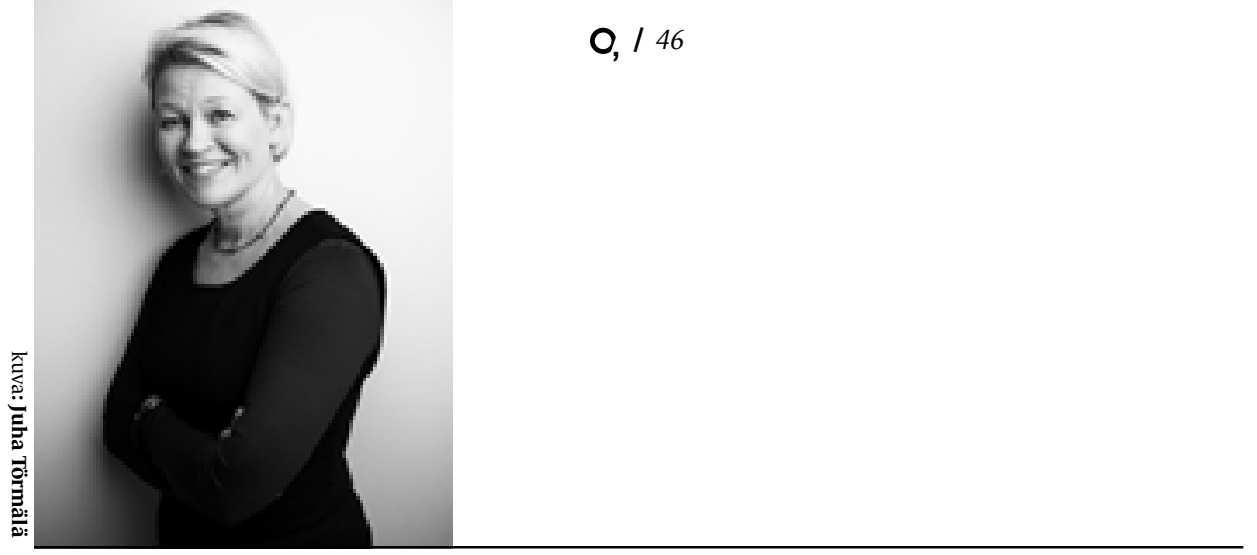

KUKA?

Elina Melgin

- Filosofian tohtori Elina Melgin toimii 25 vuoden viestintätyön kokemuksella ProCom - Viestinnän ammattilaiset ry:n toimitusjohtajana. Aiemmin hän teki töitä viestinnän, kulttuurin ja koulutuksen parissa mm. tiedotuspäällikkönä Taideteollisessa korkeakoulussa sekä toimituspäällikönä Nokia Oyj:n yhtymäviestinnässä. Useita hänen toimittamia paino-ja verkkotuotteita on palkittu koti-ja kansainvälisissä kilpailuissa.

Melgin on Global Alliance for Public Relations and Communication Management -järjestön hallituksen Advisory Councilin sekä kansainvälisen PR-historian tutkijoiden verkoston jäsen.

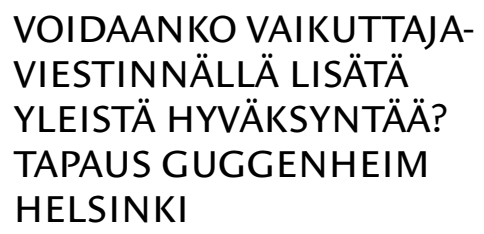

äpinäkyvyyden odotusarvot vaihtelevat kulttuurista toiseen.

Läpinäkyvyyttä edellytetään Suomessa sellaisiltakin ulkomaalaisilta organisaatioilta, joilla ei ole juridista velvollisuutta paljastaa sen enempää kaikkia avainlukujaan kuin stategioitaan julkisesti. Avoimuuden puute tai pelkän säännöstellyn informaation tarjoaminen saattaa yllättäen rapauttaa organisaation legitimiteettiä eli olemassaolon julkista hyväksyntää sidosryhmien silmissä, jos odotuksiin ei vastata. Amerikkalainen taidesäätiö Guggenheim on organisaatio, jonka museoprojekti Helsingissä tarjoaa viestijöille kiinnostavan mahdollisuuden tarkastella legitimaatioteorian valossa 
läpinäkyvyyden merkitystä sidosryhmien keskuudessa. Tässä artikkelissa pohditaan, onko jotain tehtävissä, jos avoimuuden puutteesta seuraa mainekolhuja. Voidaanko organisaation olemassaolon oikeutusta ylläpitää ja muuttaa viestinnän ja vaikuttajaviestinnän keinoin? Kuinka pitkälle sillä voidaan paikata legitimiteettivajetta ja onko moraalisesti oikein, jos mielipidejohtajien intressit ohittavat julkisen hyväksynnän?

\section{Johdanto}

Suomi on valittu viisi kertaa peräkkäin kansainvälisen Reportterit ilman rajoja -organisaation arviossa maaksi, jossa on maailman laajin lehdistövapaus (2015 World Press Freedom Index). Suomalaisessa yhteiskunnassa voidaan siis riippumattoman kansainvälisen tutkimuksen mukaan käydä muita maita vapaammin avointa julkista keskustelua. Kun Suomessa keskustellaan vapaassa mediassa ja yhteiskunnan eri foorumeilla, tietoa oletetaan olevan tarjolla riittävästi, jotta eri näkemyksiä edustavien intressit tulevat esiin. Julkinen keskustelu vaikuttaa ns. yleiseen hyväksyntään eli legitimiteettiin, joka on organisaatioiden olemassaolon perusta.

Yleisöjen luottamus organisaatioihin vaihtelee eri puolilla maailmaa ja eri toimialoilla (Salminen 2014). Kun Helsingin kaupunki tiedotti tammikuussa 2011, että se on tilannut amerikkalaiselta Solomon R. Guggenheimin säätiöltä kaksi miljoonaa euroa maksavan suunnitelman taide- museon perustamiseksi Helsinkiin, tuskin sen enempää amerikkalaiset kuin suomalaisetkaan arvasivat, millaisen julkisen reaktion suunnitelma saisi aikaiseksi. Tietoa hankkeesta ja säätiöstä piti aluksi kaivaa esiin kuin kuurupiiloleikissä. Säätiö ei projektin jatkuessa tarjonnut esimerkiksi oman toimintansa rahoituksesta tuoreita tilinpäätöstietoja verkkosivuillaan (Annual Report 2010). Säätiön toiminnan ja intressien avaaminen julkisuuteen ei vastannut suomalaisen median eikä kaikkien asiasta kiinnostuneiden, kuten taidemaailman edustajien, odotuksia läpinäkyvyydestä.

Osittaisen, asymmetrisen tiedon tarjoaminen voi aiheuttaa vakavia seurauksia organisaatiolle (Scott 2012). Guggenheim Helsinki -hanke törmäsi ensimmäisessä vaiheessa mainekolhuun, koska kaikkien hankkeelle tärkeiden sidosryhmien odotukset eivät täyttyneet. Organisaation olemassaolon oikeutus pohjautuu sen kykyyn vastata yleiseen moraaliseen kritiikkiin ja yhteiskunnalliseen keskusteluun (Salminen 2014). Museohankkeen julkinen hyväksyntä ei ollut riittävän vahvaa, vaikka sen takana oli kaupungin johto sekä taide- ja talouseliitti. Koska kaivattua selvyyttä museon rahoituksesta ja säätiön taloudellisista intresseistä ei ollut heti saatavilla, läpinäkyvyys ei toteutunut. Kun säätiö lopulta analysoi ja hyväksyi tämän seikan, museohankkeen avuksi palkattiin paikallisia oloja ymmärtävä viestintätoimisto Miltton, joka oli vuonna 2012 myyntikatteella mitattuna Suomen suurin (Kantola, Lounasmeri 2014). Alkoi projektin ns. toinen vaihe. Milttonin tehtäväksi tuli toimia neuvonantajana viestinnässä, 
vaikuttajaviestinnässä ja varainhankinnassa. Hankkeeseen palkatun asiantuntijan Sanna-Mari Jäntin mukaan tavoitteena oli mm. lisätä julkista keskustelua ja tietoa hankkeesta sekä asiakkaan ymmärrystä suomalaisesta päätöksentekoprosessista. Päättäjille ja mielipidevaikuttajille tarjottiin tietoa mielipiteiden muodostamisen tueksi (Jäntti 2015).

\section{Käsitteistä ja mielipiteistä}

Kaaviosta 1. löytyvät tälle artikkelille kes- keiset käsitteet oman aikamme merkityksillä avattuna ja kirjoittajan tulkitsemina. Vaikuttajaviestinnästä käytetään laajasti synonyymiä lobbaus, vaikka suomalaisessa kulttuurissa sillä on hieman erilainen sisältö. Molemmissa vaikuttamista harjoittavat tahot ovat kuitenkin samoja. On syytä myös tuoda esiin propagandan käsite, sillä vaikuttajaviestintä nähdään toisinaan negatiivisena propagandana, vaikka käsitteellisesti näillä on suuri ero (The Times 11.4.2015).

\section{Vaikuttajaviestintä}

Lobbaus
Keskeisin käytössä oleva suomenkielinen vastine englanninkieliselle lobbying-käsitteelle. Vaikuttajaviestintä on nimensä mukaisesti viestintää, mutta tietylle kohderyhmälle.

Tavoitteena on tuoda intressitahon kanta päätöksentekijöiden tietoon ja sitä kautta pyrkiä vaikuttamaan päätöksentekoon. Työtä tehdään taustatiedoilla, keskustelulla ja vakuuttamisella (Vaikuttajaviestintä 2014).
Ketkä tekevät:

1. Kansalaisjärjestöt, yhdistyk set ja etujärjestöt

2. Yritykset ja julkisen sektorin organisaatiot

3. Vaikuttajaviestinnän konsultit

Sama lainsäädäntö kuin muussa liiketoiminnassa

Itsesäätely

ProComilla avoin ja vapaaehtoinen vaikuttajaviestintärekisteri

Ketkä tekevät:

1. Kansalaisjärjestöt, yhdistykset ja etujärjestöt

2. Yritykset ja julkisen sektorin organisaatiot

3. Vaikuttajaviestinnän konsultit kin vaikuttajaviestintää tekevistä eli lobbareista puhuttaessa. 


\section{O, I 49}

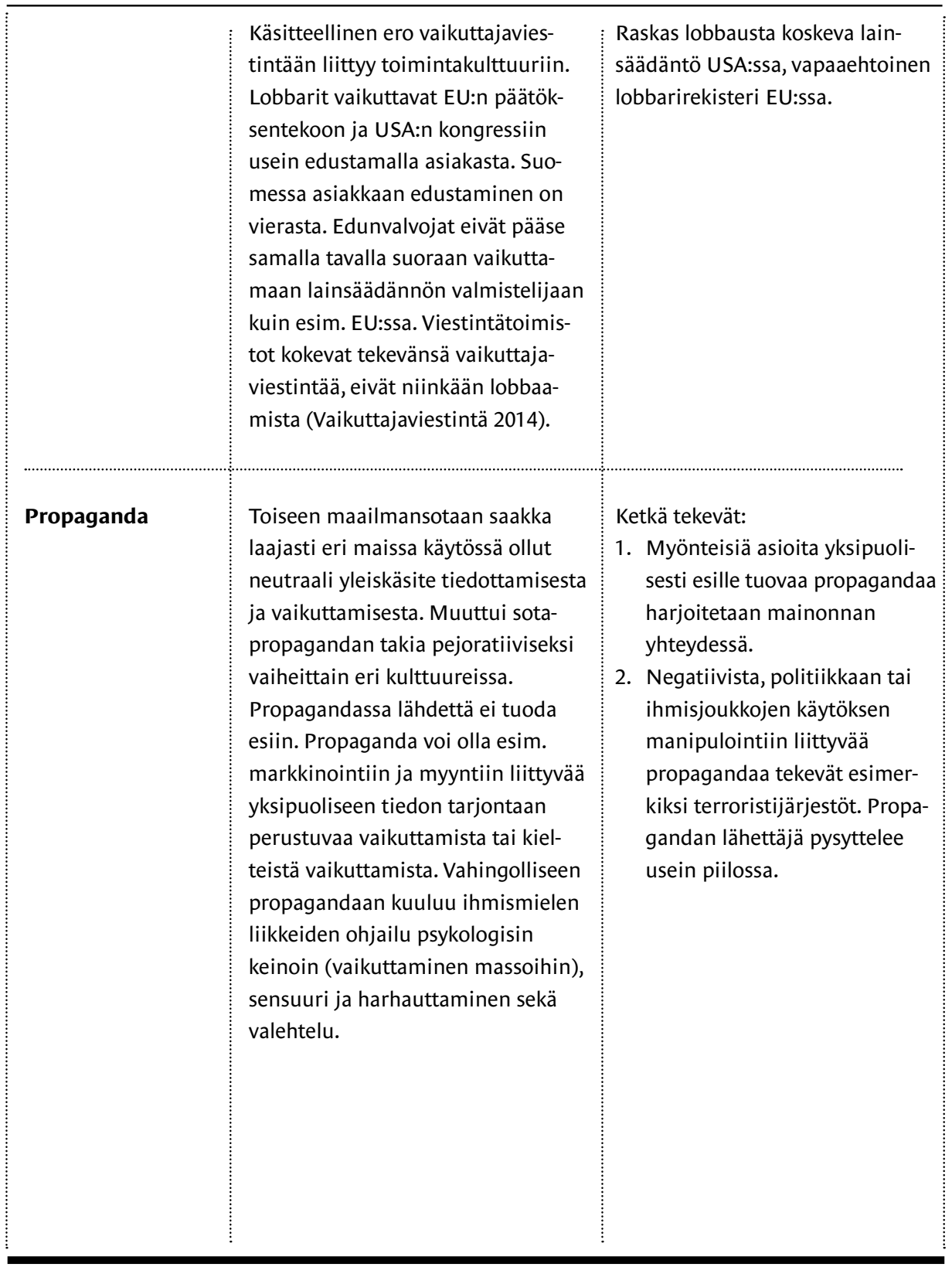




\section{O, I 50}

Tässä artikkelissa on valittu pääkäsitteeksi vaikuttajaviestintä. Millä välineillä tai tekijöillä sitten vaikutetaan päättäjiin ja muiden sidosryhmien mielipiteisiin? Leigh P. Tostin mallintamassa legitimaatioarvioinnissa voidaan erottaa seuraavat dimensiot:

1) välineellinen (kuten uskomukset oikeutuksen tarpeellisuudesta),

2) suhteisiin perustuva (kuten kysymys sosiaalisten ryhmien identiteetistä ja kunnioituksesta) sekä

3) moraalinen (ryhmien eettiset ja integriteettiin liittyvät kysymykset).

Varsinkin moraalisen dimension tarkastelusta on tullut viime vuosina tärkeä osa sosiaalisten kokonaisuuksien ja organisaatioiden legitimiteettitutkimusta. Tostin mukaan legitimaatioteoreetikot antavat paljon tilaa instituutioiden muutostutkimuksissa yksilöiden välisille suhteille ja retoriikalle muutoksen ajureina, mutta liian vähän painoarvoa sille, miten yksilöt motivoituvat toimimaan itse muutoksen käynnistäjinä tai pysyvyyden säilyttäjinä. Hän on mallintanut "legitimaatioarviointiprosessinsa" kaavioiksi (Tost 2011).

\section{Tostin malli eli legitimiteetin arvioinnin sykli}

Tostin mukaan organisaation legitimiteetti on paitsi kansalaisten, myös päättäjien jatkuvan arvioinnin kohteena. Arviointiin voidaan vaikuttaa eri tavoin. Tostin teoreettinen malli havainnollistaa, miten erilaiset suhtautumistavat ja keinot vaikuttavat yksilöiden ja ryhmien ajatteluun muutosprosessissa.

\section{Kaavio.}

Tost, L. P, (2011) An Integrative Model of Legitimacy Judgements. Academy of Management Review, 36(4): 695. 
O, / 51

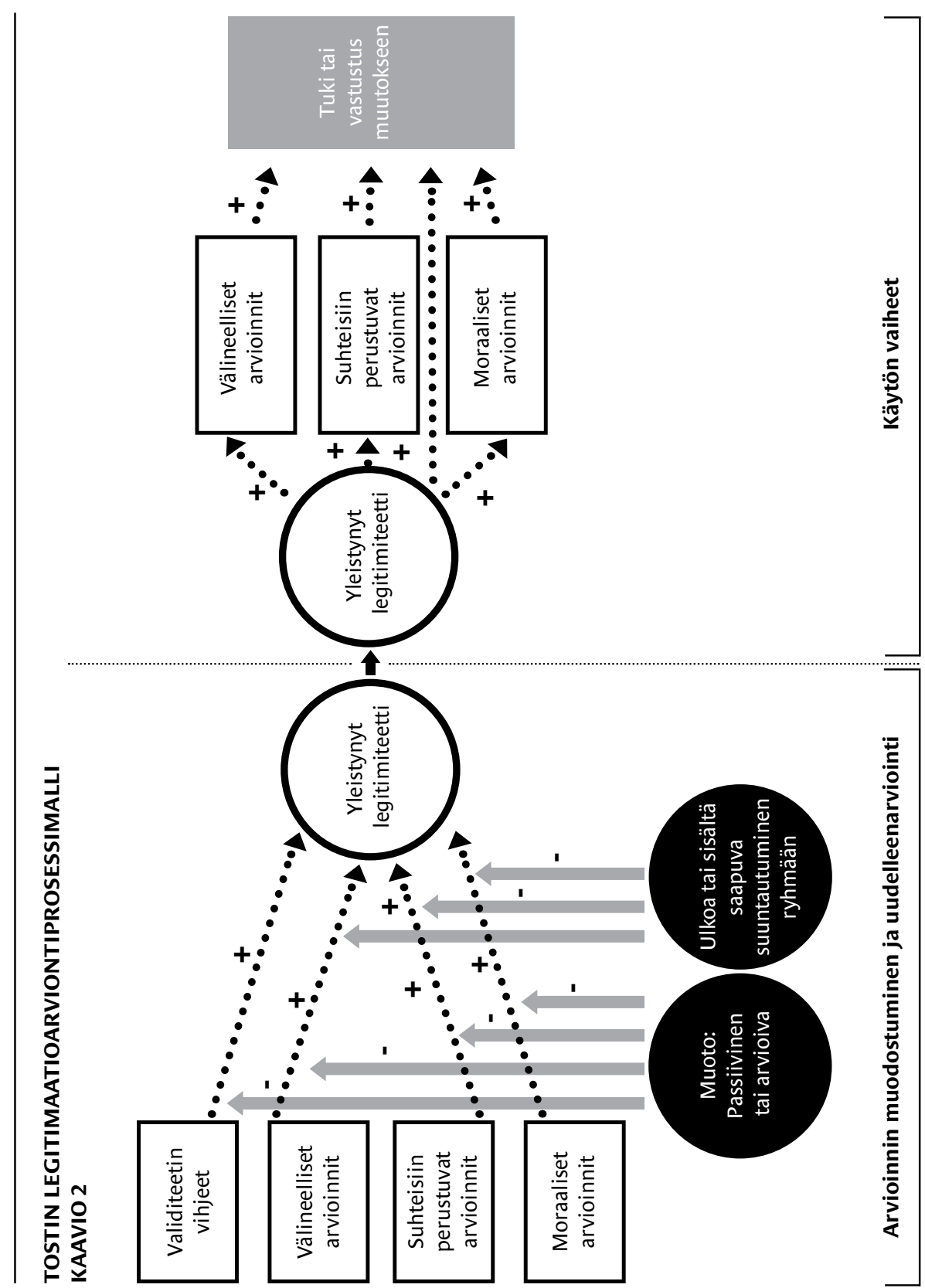


Suhtautuminen organisaation legitimiteettiin voi olla arvioiva tai passiivinen. Tämä voi vaihdella sen mukaan, tuleeko ulkoa- tai sisältäpäin yllättäviä tekijöitä, jotka aktivoivat erilaisten sidosryhmien passiivisen suhtautumisen aktiiviseksi tai päinvastoin.

Organisaatiot ovat tietoisia ulkoisten tekijöiden vaikutuksista ja huolehtivat siksi maineestaan ennakoivasti tarkkailemalla ympäristöä, kuten oman toimialan vaikutuksia organisaation toimintaan ja brändiin. Organisaatiot pyrkivät myös itse vaikuttamaan legitimiteettiinsä vahvistamalla sidosryhmäsuhteitaan, tarjoamalla välineellisiä vaikutteita tai nostamalla esiin sellaista dialogia tai tietoa, jolla on merkitystä sidosryhmien moraalisiin pohdintoihin.

Pyrin seuraavassa tarkastelemaan tapaus Guggenheim-museoprojektia Tostin teorian valossa. Museoprojektin vaiheessa yksi, jolloin projekti koki Suomessa vastustusta, korostuivat etenkin Tostin mallin mukaiset välineelliset sekä moraaliset dimensiot.

\section{Vaihe 1: idean myyminen epäonnistui}

Korkean profiilin demokratiassa vallitsee niin sanottu all-affected-periaate, joka on tuttu sidosryhmäteorioista. Sen mukaan kansalaisilla on oikeus osallistua sellaiseen poliittisen päätöksentekoon, joka koskee heitä. Todellisuus ja teoria eivät kuitenkaan aina kohtaa, eivät varsinkaan monimutkaisessa ylikansallisessa poliittisessa kontekstissa, jossa demokratiakäsitys vaihtelee (Karlson 2009). Suomi on pieni ja avoin yhteiskunta, jossa lähes kuka tahansa pääsee halutessaan päätöksentekijän puheille. Päätöksentekijöiden ja intressiryhmien kanssakäymistä on helppo seurata, ja se on turvattu lailla.

New Yorkissa toimivalla ja globaalisti museotoimintaa harjoittavalla Guggenheim-säätiöllä ei ollut aluksi selvää käsitystä paikallisista päätöksentekomekanismeista eikä myöskään siitä, miten Suomessa käydään julkista dialogia. Kulttuuriset erot paljastuivat museohankkeen myyntivaiheessa eli vaiheessa yksi, kun hankkeen alustava rahoitusselvitys tuli julkiseksi. Helsinkiläiset halusivat ja saivat puuttua museota koskevaan julkiseen keskusteluun ja pääsivät sitä kautta vaikuttamaan poliittiseen päätöksentekoon. Taideprojektista tuli poliittinen projekti.

Julkinen keskustelu vapaassa mediassa tarkoitti sitä, että sekä museota puoltavien että sitä kyseenalaistavien argumentit pääsivät julkisuuteen. Tostin kaavion mukaisesti organisaation legitimiteetti joutui uudelleenarvioinnin kohteeksi. Kaupunkilaiset kiinnittivät huomiota, moni ensimmäistä kertaa elämässään, museohanketta ajavaan säätiöön. He saivat median avulla tietoa, jonka turvin muodostivat kantansa. Läpinäkyvyys lisääntyi, mutta tietoa tuli äkillisesti ja ristiriitaisesti. Koska keskustelun ytimessä dominoi puhe museon rahoituksesta, hanke kosketti välineellisesti sellaisiakin, joita taide sinänsä ei kiinnostanut. Keskiössä oli puhe julkisesta rahoituksesta: se kietoutui hankkeen ja sitä ajavan organisaation moraaliseen arviointiin.

Hankkeen ensimmäisessä vaiheessa joidenkin kansalaisten kritiikki kohdistui 
säätiön valmistamaan talousarvioon museon pyörittämisestä. Arvostelu kohdistui

1. säätiön vaatimiin suuriin lisenssimaksuihin

2. ulkopuolisen, talouselämän tarpeisiin erikoistuneen, kansainvälisen konsulttitoimiston tekemien investointilaskelmien realistisuuteen (pääsylipputulot, vero varojen käyttö)

3. kulttuurisen investoinnin tarpeellisuuteen (valmiiksi tiheä museoverkosto, Suomi on lähtökohtaisesti kulttuurimaa) sekä

4. epäilyksiä herättävään viestintätapaan (läpinäkyvyyden puute hankkeen varhaisessa valmistelussa), (Esim. Suomen Kuvalehti 27.1.2012; Guggenheimin varjossa 2012; Tehtävä kulttuurille 2014).

Guggenheim Helsinki -tapaus osoittaa, että yksilöt ja heidän muodostamansa intressiryhmät voivat mielipiteineen joko ryhtyä vahvistamaan tai rapauttamaan organisaation legitimiteettiä. Jo vaiheessa yksi puolustajien joukossa esiintyi julkisesti keskeisiä talous- ja taide-elämän vaikuttajia. He pääsivät äänitorviksi mediaan vahvistamaan auktoriteetin näkemystä ja hankkeen oikeutusta. Auktoriteettia edusti tietenkin myös amerikkalainen taidesäätiö, jonka asema taiteen kentällä oli kansainvälisesti vakiintunut. Taidesäätiö nautti hyvästä maineesta koko kansainvälisellä kulttuurisektorilla. Toimialaa koskeva yleinen myönteinen mielikuva vaikuttaa siihen, että organisaation legitimiteetti koetaan lähtökohtaisesti vahvana
(Deephouse, Carter 2005). Auktoriteettia edusti myös Helsingin kaupungin ylin johto sekä valikoidut paikalliset taide-elämän vaikuttajat eli hankkeen veturit.

Vastustavan puolen yksilötason toimijat haastoivat "epäilijöiden" tai "vastustajien" ulostuloina auktoriteettien puhetta nostamalla mielipidekirjoituksissa esiin etenkin amerikkalaisen museobrändin moraaliseen oikeutukseen vetoavia argumentteja. Vastustajat eivät muodostaneet Checkpoint Helsinki -nimistä taiteilijaryhmää lukuun ottamatta suoranaisia aktivistiryhmiä. Argumentaatiossa tulivat esiin kaikki edellä mainitut Tostin esittämät dimensiot, mutta moraaliseen dimensioon kiedottu puhe julkisesta rahasta oli korostunutta. Puolustajien näkemystä siitä, että museo olisi turistirysä ja tulevaisuuden investointi, vastustettiin.

Ulkomainen lehdistö nosti esiin vaikutusvaltaisia kulttuuripersoonia molemmista mielipidevaikuttajien leireistä, mutta tyytyi enimmäkseen toteamaan, että Suomen täytyy nyt päättää, haluaako se vastaanottaa tämän amerikkalaisen museon vai ei. Ulkomainen lehdistö pyrki tarjoamaan neutraalia uutisointia ilmiöstä eikä siis asettunut lähtökohtaisesti tukemaan säätiön hanketta Suomessa (Esim. Daily Telegraph 2014). Tarpeeksi painavia taloudellisia perusteita ei kummallakaan mielipideleirillä ollut esittää.

Museosta käyty julkinen ja avoin kriittinen keskustelu vaikutti siihen, että helsinkiläisten kunnallispoliitikkojen oli mietittävä äänestäjiään (vaalien alla) ja säätiön sekä paikallisten taidemaailman organisaatiokumppaneiden oli mietittä- 
vä taidekentän henkistä jakaantumista kahtia. Kaupungin johto puolestaan joutui pohtimaan omaa mainettaan kyseenalaiseksi leimatun hankkeen rahoittajana. Guggenheim-säätiön myönteiseen asemaan taidekentän edustajana kohdistui merkittäviä moraalisia epäilyksiä, ja ne lisääntyivät edelleen siinä vaiheessa, kun kaupungin tärkeintä edustajaa hankkeessa epäiltiin taloudellisten kytköksiensä takia jääviksi (Oikeusasiamiehen päätös 2013). Säätiön ja Helsingin kaupungin johdon valmistelema museon rahoitussuunnitelman ehdotus hävisi kaupunginhallituksen äänestyksen, mutta vain yhdellä äänellä.

Vaikka tietoa sekä säätiöstä että museohankkeesta oli avoimesti tarjolla enemmän kuin hankkeen lanseerauksen aikaan, epäluulot elivät sitkeinä. Käsitys siitä, että todelliset intressit olivat piilossa, eivät tukeneet kaupunkilaisten mielikuvia läpinäkyvyydestä. Säätiö laittoi museoprojektinsa lepäämään lähes vuodeksi.

Sinä aikana säätiö loi uuden strategian, jota alettiin toteuttaa tehtävään valikoidun paikallisen viestintätoimisto Milttonin avulla. Sekä säätiön asiamiehille että kaupungin edustajille oli kirkastunut tosiasia, että vastakkaisten näkökulmien yhteensovittamiseen tarvitaan paikallista toimintakulttuuria ja arvoja sekä päätöksentekoprosesseja tuntevien viestintäammattilaisten työtä. Tarvittiin myös entistä enemmän avoimuutta. Alkoi projektin vaihe 2 , joka on edelleen käynnissä tätä artikkelia kirjoitettaessa.

\section{Vaihe 2: eteneminen sidosryhmä- vuoropuhelun kautta}

Lobbaus tuli esille useaan otteeseen varsin kielteisessä sävyssä valtakunnan päämediassa Yleisradiossa juuri samaan aikaan, kun Miltton palkattiin Guggenheim-museohankeen promootiotyöhön käynnistämään säätiön uutta yritystä saada julkista tukea Helsingissä. Vaikka lobbausta on harjoitettu vuosisatoja (Yle Areena 3.2.2014) ja sitä harjoitetaan runsaasti edelleen kulissien takana, nousi lobbaus paradoksaalisesti kielteisessä sävyssä otsikoihin Suomessa juuri silloin, kun sille annettiin selkeämmin ymmärrettävä ja läpinäkyvä muoto. Media käytti sekä vastaperustettua yritystä, Milttonin vaikuttajaviestintään erikoistunutta sisaryhtiötä Miltton Networksiä, että Guggenheim Helsinki -museotapausta esimerkkeinä epäilyttävästä vaikuttajaviestinnästä. Median kautta välittyi yleisölle sellainen mielikuva, että lobbaus on ihmisten harhaanjohtamista (kuten propaganda) ja kulissien takana maksusta harjoitettua hämärähommaa (Esim. Yle 8.1.2014).

Milttonille itselleen Guggenheim Helsinki -projektista muodostui sen liiketoiminnassa erityistapaus, koska asiakas oli ulkomaalainen eikä voinut olla läsnä Suomessa antamassa lausuntoja medialle ja käymässä keskustelua sidosryhmien kanssa. Milttonin tehtäväksi tuli osittain käyttää asiakkaansa ääntä, ja tästä syystä Milttonin rooli ja hankkeen rooli näyttivät menevän sekaisin mediassa. Ihmisillä oli vaikeuksia ymmärtää asiakkaan ja konsulttitoimiston työnjakoa, koska Suomessa ei ollut totuttu sellaiseen. Guggenheim-ai- 
heen herättäessä runsaasti kiinnostusta Miltton päätyi mediaan paljon aktiivisempana toimijana kuin viestintätoimistot tyypillisesti (Jäntti 2015).

Guggenheim Helsinki -hankkeen ns. toisessa vaiheessa siirryttiin etsimään hankkeelle laajempaa yleistä hyväksyntää sekä päättäjien että heihin vaikuttavien äänestäjien parissa. Vaikutustyö jälkimmäiseen ryhmään tapahtui mm. mielipidevaikuttajien avulla. Vaikuttajaviestinnän tavoitteena oli saada hankkeen taakse riittävä poliittinen tuki, jotta museohanke saataisiin seuraavassa äänestystilanteessa hyväksytyksi.

Vaikka Tostin mallissa legitimiteetin uudelleenarviointi on kokonaisvaltaista kaikilla dimensioiden (välineellinen, suhteisiin perustuva, moraalinen) tasoilla, on tärkeää huomata, että yksilöiden kokonaisarviossa painavat myös ennakkoluuloon ja puolueellisuuteen luokiteltavat seikat. Yleiseen mielipiteeseen vaikuttavat lisäksi taloudellinen ja yleinen kulttuuripoliittinen ilmapiiri maassa. Tostin mukaan jokin dimensioista vaikuttaa uudelleenarviointiin huomattavasti enemmän kuin toinen.

Tämän hankkeen tarkastelussa vaikuttaa siltä, että projektin ensimmäisessä vaiheessa painoivat etenkin välineelliset (julkinen rahoitus) ja moraaliset seikat (onko oikeutettua kohdistaa julkista rahaa ulkomaiselle museohankkeelle). Hankkeen toisessa vaiheessa annettiin enemmän aikaa ja tilaa keskustelulle, jotta sekä kriittiset että hanketta kannattavat äänet pääsisivät esille. Tostin teorian mukaisesti tapahtui suhteisiin perustuvaa uudelleenarviointia. Suomessa päättäjien määrä on suhteel- lisen pieni. Guggenheim-museohanketta puoltavien korkean profiilin päättäjien lausunnot julkisuudessa ovat hyvin todennäköisesti vahvistaneet sellaisten yksilöiden, jotka haluavat samaistua näiden päättäjien joukkoon, uudelleenarviointia hankkeesta. Kannastaan epävarma on voinut spekuloida sillä, että voisi puoltaa hanketta, koska sen kannattajien joukosta erottuu hyvin vaikutusvaltaisia ihmisiä.

Huomioyhteiskunnassa mielipiteiden näkyminen ja oikeiden luottojoukkojen löytyminen ideoiden taakse vaatii entistä enemmän työtä. Viestintätoimiston työnä on hyvin todennäköisesti ollut löytää sopivia mielipidejohtajia projektin puolestapuhujiksi. Museohankkeen edistämiseksi on perustettu julkisuuden henkilöiden profiloima, mutta kaikille avoin Guggenheim Helsinkiin -yhdistys (ry) tehtävänään mm. varainhankinta museon arkkitehtuurikilpailua varten. Se myös tukee Guggenheim Helsingin Tukisäätiötä (Jäntti 2015). Varainkeruun keulassa on näkynyt esimerkiksi Sanoma-konsernin omistajiin kuuluva Rafaela Seppälä, mainosmaailman vaikuttaja Ami Hasan sekä Suomen kansainvälisimpiin muotoilijoihin kuuluva Harri Koskinen.

Kaikilla sidosryhmillä ei ole välttämättä mitään tarvetta leimautua sen enempää talous- kuin kulttuurieliittiinkään. Tostin legitimaatioteoreettisessa arvioinnissa näiden yksilöiden kohdalla painavat arvioinnissa muut syyt. Ne henkilöt, joilla ei ole voimakkaita suhteisiin perustuvia vaikutteita tai moraalisia näkökulmia päätöksenteon taustalla, kuten jo mainittu, perustavat arviointiaan ulkoa tuleviin 
välineellisiin arviointeihin. Vaakakupissa painavat esimerkiksi henkilökohtaiset intressit. Tostin mallissa nämä yksilöt ovat keskimäärin vähemmän kriittisiä arvioinnissaan etenkin, jos he näkevät kytköksen omiin intresseihinsä. Hyödynkö museon tulosta? Menetänkö mahdollisesti jotakin? Viestinnällisesti on nostettu esiin hankkeen yhteiskunnallista merkitystä helsinkiläisten työllistäjänä (Guggenheim Helsinki -verkkosivut 2015; Jäntti 2015).

\section{Entä läpinäkyvyys?}

Sidosryhmien odotukset ovat osittain ohjailtavissa viestinnän avulla. Odotukset muodostuvat etupäässä aikaisempien kokemuksien, organisaation toiminnan ja viestinnän perusteella. Läpinäkyvällä viestinnällä on vaikutusta. Viestinnän tehtävänä on tarjoilla sidosryhmille mahdollisimman oikea-aikaista, relevanttia ja avointa tietoa. Jäntin mukaan ongelmallisinta museohankkeen projektiviestinnässä on ollut virheellisen tai puutteellisen tiedon määrä, mikä koskee sekä säätiötä että sen muuta globaalia museotoimintaa. Jäntin mukaan Guggenheim Helsinki -projektilla on kannattajien ja vastustajien rinnalla suuri joukko kannastaan edelleen epävarmoja yksilöitä, joille viestintää suunnataan mahdollisimman neutraalisti siten, että avoimissa tilaisuuksissa saavat äänensä kuuluville myös hankkeen vastustajat (Jäntti 2015). Läpinäkyvyys kuuluu siis tämän projektin toisen vaiheen strategiaan.

Välineellisiä arvoja korostava arviointi ei välttämättä anna moraalisen spekuloinnin häiritä. Esimerkiksi pohdinta siitä, mistä verovaroin ylläpidettävän museon pyörittäminen saattaa olla pois, ei välttämättä vaikuta välineellistä argumentaatiota painottavan henkilön arviointiin lainkaan. Eettisesti arvioiva sen sijaan kysyy, kärsiikö mahdollisesti jonkun muun tärkeän hankkeen rahoitus museon tulon takia. Jäntin mukaan rahoituskysymys on koko projektiviestinnän haastavin kysymys. Kukaan ei voi varmuudella todistaa, mistä julkinen rahoitus mahdollisesti olisi pois. Tätä kysymystä Miltton ei ole halunnut viestinnässään millään tavalla peitellä (Jäntti 2015).

\section{Arkkitehtuurikilpailu: onko oikein ohjata yleistä mielipidettä?}

Strategisesti viestintäänsä suunnitteleva ja toteuttava organisaatio saattaa olla niin tehokas työssään, että sidosryhmien huomio kiinnittyy juuri sinne, minne organisaatio itse sen ohjaa. Kuten Tost osoittaa, ihmisillä on luontevasti tapana uskoa instituutioiden legitimiteettiin enemmän kuin kyseenalaistaa sitä ja ryhtyä aktiiviseen muutosprosessiin. Arviointi on jatkuvasti auki uudelle informaatiolle, ja eri painotukset voivat muuttaa alkuperäistä käsitystä tai suhdetta organisaation olemassaolon oikeutukseen (Tost 2011). Jäntin mukaan Milttonin tehtävänä on ollut tarjota mahdollisimman paljon oikeaa tietoa hankkeesta, jotta lopputulos, mikä se sittenkin onkin, ei perustuisi puutteelliseen tietoon (Jäntti 2015).

Kun Guggenheim Helsinki -hankkeen toinen vaihe käynnistyi, kuntalaiset saivat lukea lehdistä, että taidesäätiö ryhtyi rahoittamaan museorakennuksen arkkiteh- 
tuurin kilpailutusta Helsingin etelärannan tontille. Tämän viestin avulla ne kuntalaiset, jotka eivät tienneet, että päätös museon synnystä vielä puuttui, saattoivat ajatella, että museo on jo rakenteilla eli sille on löydetty riittävä poliittinen tuki taakseen. Strategisena valintana arkkitehtuurikilpailun lanseeraaminen voidaan tulkita nerokkaaksi tavaksi vaikuttaa niiden ihmisten mielikuviin, jotka eivät ole varmoja kannastaan sekä niihin, jotka eivät seuraa museoprojektin vaiheita tarkasti tai mahdollisesti olettavat museon joka tapauksessa tulevan Helsinkiin.

Arkkitehtuurikilpailu voidaan nähdä tämän projektin viestinnän keskeisenä keinona. Sen avulla hankkeesta on päästy kertomaan kokonaan uudella tavalla. Arkkitehtuurikilpailun loppusuoralle valittujen arkkitehtien esiintyminen sekä suomalaiselle medialle että yleisölle ovat tästä esimerkkinä. Kilpailun loppusuoralle valituille järjestettiin mahdollisuus vastata erilaisiin yleisön kysymyksiin, jotka koskivat paitsi museota myös Helsinkiä ja Suomea yleensä. Jos tätä hanketta tutkittaisiin yksittäisten maineeseen vaikuttavien tapahtumien kautta, ns. actional legitimation -teorian eli tekojen myötä syntyvän teorian valossa (Boyd 2009) voitaisiin ainakin spekuloida, että aiemmin huomattavan kielteisestikin esillä ollut museohanke sai selkeästi positiivisempaa nostetta arkkitehtuurikilpailun lanseerauksen sekä siihen liittyvän viestinnän avulla.

\section{Mihin eettistä pohdintaa tarvitaan?}

Tostin malli tarjoaa mahdollisuuden asettaa kysymyksiä ja pohtia yksilöiden ja yksilöistä muodostuvien ryhmien vaikutusta organisaation maineeseen ja legitimiteettiin. Onko Guggenheim Helsinki -hankkeen läpinäkyvyyden lisääntyminen johtanut eettisten kysymyksien määrän lisääntymiseen, kuten teoreetikot otaksuvat tapahtuvan (De Tienne \& Lewis, 2005)? Uskaltaisin vastata tähän, että kyllä ja ei. Hankkeen toinen vaihe ei näyttäydy mediassa yhtä ristiriitaisessa valossa kuin sen ensimmäinen vaihe, vaikka kritiikkiäkin on edelleen esiintynyt (Taloussanomat 13.12.2014; YLE 4.6.2014). Viestinnällä on siis saatu tuloksia aikaiseksi. Milttonin työ Guggenheim Helsinki -hankkeessa palkittiin European Excellence Award -palkinnolla 2014 sarjassa Public Affairs nimenomaan avoimesta viestinnästä sekä hankkeen arkkitehtuurikilpailun organisoinnista (Winnerlist 2014). Kritiikkikin on onnistuttu osittain kääntämään myönteiseksi. Kansainväliset arkkitehdit pitivät tammikuussa 2015 museon ympärillä vellovaa kiistelyä merkkinä terveestä yhteiskunnasta (HS 15.1.2015).

Voidaan silti spekuloida, onko moraalisesti oikein, että strategisesti valituilla toimenpiteillä, ajankulun hyödyntämisellä sekä taitavalla avoimella viestinnällä on aikaansaatu suopeutta hankkeelle, jolle ei vielä edes ole olemassa poliittista päätöstä. Moniin viestintäkampanjoihin kuuluu luonnollisena osana julkisuuden hallinnan lisäksi poliittinen lobbaaminen (Kantola, Lounasmeri 2014). Miltton itse korostaa juuri läpinäkyvällä viestinnällä tehtävää työtä lobbauksen sijaan (Jäntti 2015 b).

Ydinkysymykset eivät katoa mihinkään, vaikka hankkeen viestintä olisi hoidettu 
tehokkaasti. Sellaisiin kuntalaisten kysymyksiin, kuten voivatko virkamiehet tai luottamusmiehet käydä luottamuksellisia keskusteluja hanketta valmistelevan yksityisen säätiön ja tätä edustavien lobbareiden kanssa, viestintä ei anna vastausta. Kuten ei siihenkään, tulisiko tietojen vaihto katsoa osallistumiseksi valmisteluun (Sorjanen 2015).

Miksi Guggenheim-säätiö haluaa juuri Helsinkiin? Säätiön virallinen vastaus korostaa sitä, että amerikkalaista taidesäätiötä kiehtoo Helsingissä muita maailman kaupunkeja enemmän kaksi painavaa seikkaa: geopoliittinen sijainti (portti Aasiasta Eurooppaan ja päinvastoin sekä Venäjän läheisyys) ja maan tietopääoma (Jäntti 2015). Nähtäväksi jää, mikä sitten loppupeleissä voittaa: runsaalla, avoimella ja mielipidejohtajien esimerkkiä hyödyntävällä viestinnällä aikaansaatu kuntalaisten lisääntynyt suopeus ja sitä kautta poliittinen tuki hankkeelle vai hankkeen rahoitukseen ja taidesäätiön taloudellisiin intresseihin liittyvät vakavat epäilyt ja niistä johtuva poliittinen vastustus museon rakentamiselle. Museota ei välttämättä vastustettaisi niin paljon, jos se ei tarvitsisi niin paljon julkista rahoitusta.

Tämän tapauksen ja teorian valossa on mahdollista esittää, että:

1. Organisaation olemassaolon oikeutukseen voidaan vaikuttaa viestinnällisin keinoin.

2. Se onnistuu, mikäli viestinnässä ja vaikuttajaviestinnässä on onnistuneesti huomioitu paikallisen kulttuurin erityispiirteet.

3. Vaikuttajaviestinnän voima riittää paikkamaan legitimiteettivajetta jonkin aikaa, mutta pysyvään muutokseen vaikuttavat organisaation toiminta ja sidosryhmien kokemukset.

4. Suomessa koetaan yleisesti, että on moraalisesti väärin, jos mielipidejohtajien intressit ohittavat julkisen hyväksynnän. Demokratia toteutuu kuitenkin laissa hyväksyttyjen mekanismien turvin. Päätöksiä syntyy, mikäli demokraattinen enemmistö niin päättää.

\section{Lähteet}

Annual Report 2010

Säätiön sivustolla viimeisin kertomus tilinpäätöstietoineen on vuodelta 2010. http://www.guggenheim.org/guggenheim-foundation/annualreports?year $=2010$ Viitattu 22.4.2015

Boyd, J. (2009). Actional Legitimation: No Crises Necessary. Journal of Public Relations Research, 12(4), 341-353.

Sorjanen A. (2015). "Sanokaa G, kun haluatte taidekohua". http://blogit.yle.fi/ strada/sanokaa-g-kun-haluatte-taidekohua Viitattu 24.2.2015.

Guggenheim Helsinki -verkkosivut http://www.guggenheimhki.fi/

Guggenheimin varjossa (2012). Toim. Kaarin Taipale. Helsinki, Into.

Daily Telegraph 15.7.2014 
"An uncertain Finland, torn between rye bread and burger buns, an innate national modesty and brash global "branding", must decide". Finland fights the Guggenheim invasion. http://www.telegraph.co.uk/ culture/art/architecture/10894439/Finland-fights-the-Guggenheim-invasion.html Viitattu 18.2.2015.

Deephouse D.L \& Carter S. M. (2005). An Examination of Differences Between Organizational Legitimacy and Organizational Reputation. Journal of Management Studies 42 (2), 329-360.

DeTienne, K. \& Lewis, L. 2005. The Pragmatic and Ethical Barriers to Corporate Social Responsibility Disclosure: The Nike Case. Journal of Business Ethics 60, 359-376.

Jäntti, Sanna-Mari, Miltton Networksin Senior Advisor 16.2.2015. Haastattelu. Tekijän hallussa.

Jäntti, Sanna-Mari 2015 b. Sähköpostiviesti tekijälle 22.4.2015.

Kantola A, Lounasmeri L. (2014). Viestinnän ammattilaiset promootioyhteiskunnassa: aktivisteja ja ajatusjohtajia. Media ja viestintä 37: 3-21.

Karlson, J. (2009). The transnational democracy: Alternatives to the all affected principle of democratic inclusion boundaries of democratic inclusion. http://www.mothugg.se/wp-content/ uploads/2010/04/Johan-Karlsson-Alternatives-to-the-AAP-ISA09.pdf
Viitattu 18.2.2015

HS 15.1.2015

"Guggenheim-finalistit pitävät museoriitelyä terveenä merkkinä demokratiasta" http://www.hs.fi/ kulttuuri/a1421294738689?jako=83cc65130f47b2686c40d163b3b17d35\&ref=fb-share

Viitattu 24.2.2015

Oikeusasiamiehen päätös 2012 dnro $182 / 4 / 2012$

http://www.oikeusasiamies.fi/Resource. phx/pubman/templates/2.htx?id=976 Viitattu 24.4.2015

Salminen H. (2014). Viestinnän osaajasta strategiseksi vuorovaikuttajaksi - viestinnän johtajuus 2010-luvulta eteenpäin. Sosiaalitieteiden laitoksen julkaisuja 19. Helsingin yliopisto.

Scott, W. R (2012). Information Assymmetry. Financial Accounting Theory, 124-130, Pearson Canada.

Suomen Kuvalehti 27.1.2012

"Tilastotutkija kyseenalaistaa Guggenheim-matematiikan" http://suomenkuvalehti.fi/jutut/kulttuuri/ tilastotutkija-kyseenalaistaa-guggenheim-matematiikan/

Viitattu 24.3.2015

Taloussanomat 13.12.2014.

"Saksassa ihmetellään, selättääkö

Guggenheim Helsingin"

http://www.taloussanomat.fi/markkinoin- 


\section{O, I 60}

ti/2014/12/13/saksassa-ihmetellaan-selattaako-guggenheim-helsingin/201417154/135 Viitattu 24.2.2015

The Times 11.4.2015

"Councils accused of hiring spin-doctor army of thousands"

http://www.thetimes.co.uk/tto/news/politics/article4408056.ece

Viitattu 11.4.2015

Tehtävä kulttuurille (2014). Toim. Lehtonen Mikko, Valaskivi Katja \& Kuusela Hanna. Vastapaino.

Tost, L. P, (2011). An Integrative Model of Legitimacy Judgements. Academy of Management Review, 36(4), 686-710.

Vaikuttajaviestinnän tila 2014 Suomessa ja kanta säätelyyn.

http://procom.fi/wp-content/uploads/2014/01/Vaikuttajaviestinn\%C3\%A4n-tila-Suomessa-ja-kanta-s\%C3\%A4\%C3\%A4ntelyyn.pdf Viitattu 26.2.2015

Vaikuttajaviestintä 2014 -tutkimus http://procom.fi/wp-content/uploads/2014/05/Vaikuttajaviestint\%C3\%A4-2014.pdf

Viitattu 26.2.2015

Winnerlist 2014 http://www.excellence-awards.eu/winnerlist-2014/

Viitattu 24.2.2015
YLE 8.1.2014

"Poliitikkojen siirtyminen lobbaajiksi huolestuttaa oikeusoppineita" http://yle.fi/uutiset/poliitikkojen_siirtyminen_lobbaajiksi_huolestuttaa_oikeusoppineita/7020561

Viitattu 24.4.2015

\section{YLE 4.6.2014}

"Guggenheim-pomo suivaantui Yle -uutisten kysymyksistä" http://yle.fi/uutiset/guggenheim-pomo_suivaantui_yle_uutisten_kysymyksista_-_katso_video/7277923

Viitattu 24.4.2015

YLE Areena 3.2.2014

"Lobbauksen historia, Magna Carta" http://areena.yle.fi/radio/2127646

Viitattu 24.4.2015

2015 World Press Freedom Index http:// index.rsf.org/\#!/)

Viitattu 18.2.2015 


\section{KEHITY VIESTINNÄN AMMATTILAISENA}

\section{Olemme järjestäneet yliopistollista viestinnän}

täydennyskoulutusta ammattilaisille jo 30 vuoden ajan.

Koulutus muodostaa kolmiportaisen opintopolun viestinnän perusteista viestinnän johtamiseen.

Lisäksi järjestämme täsmäkoulutuksia, joiden teemoja ovat muun muassa viestinnän suunnittelu, sosiaalinen media, kriisiviestintä, dialogi ja viestintäoikeus.

- Opiskelijamme työskentelevät yrityksissä, järjestöissä ja julkisella sektorilla

- Kouluttajamme ovat arvostettuja viestinnän ammattilaisia

- Teemme tiivistä yhteistyötä Helsingin yliopiston viestinnän oppiaineen kanssa

- Räätälöimme tilauskoulutuksia tarpeidenne mukaan, ota tarvittaessa yhteyttä

\section{TIEDUSTELUT}

marita.parkkonen@helsinki.fi, p. 0505880777 tiina.rintala-siira@helsinki.fi, p. 0503175560 minna-maija.salomaa@helsinki.fi, p. 05038800684

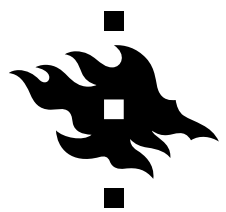

HELSINGIN YLIOPISTO KOULUTUS- JA KEHITTÄMISPALVELUT 
vämpää tietoa kaikista organisaation menestykseen vaikuttavista tekijöistä. Siksi pelkän taloustuntemuksen sijaan sijoittajasuhteiden harjoittajilta vaaditaan yhä enemmän myös syvällistä viestinnän ymmärrystä. Koska Suomessa arvopaperimarkkinalaki määrää listattuja yrityksiä läpinäkyvän ja avoimen sijoittajaviestinnän harjoittamiseen, strateginen epämääräisyys voidaan nähdä sijoittajaviestinnän kontekstissa läpinäkyvyydelle vastakkaisena viestintästrategiana.

\section{Äärimmäiset olosuhteet ajoivat kaivos-} yhtiö Talvivaaran viestinnällisiin strategioihin, joiden etiikka mietityttää niin sijoittajia kuin viranomaisiakin. Miten viestiä silloin, kun organisaatio tasapainottelee sidosryhmien kärjistyneiden odotusten kanssa tai kun yhdellä viestillä on tavoitettava useita, keskenään ristiriitaisia tavoitteita? Onko ehdoton läpinäkyvyys aina tehokkain viestinnällinen strategia? Voiko pörssiyhtiö viestiä strategisen epämääräisesti ja toimia silti edelleen eettisesti? Artikkeli pohtii näitä kysymyksiä Talvivaaran sijoittajaviestinnän ja siinä esiintyneen strategisen epämääräisyyden näkökulmasta, todeten, että liian myönteiset viestit voivat heijastaa läpinäkyvyyden puutetta.

\section{Johdanto}

Luotettava sidosryhmäviestintä on välttämätöntä sijoittajien päätöksenteon tueksi. Pörssiyhtiöiden tiedottamisvelvollisuus korostuu entisestään epävakaissa olosuhteissa. Läpinäkyvä ja vastuullinen viestintä organisaation taloudellisesta tilanteesta, tulevaisuuden näkymistä ja markkinoiden vaikutuksesta yrityksen vakavaraisuuteen (Kelly, Laskin \& Rosenstein 2010) on yksi legitimiteetin ansainnan vaatimus, jolle koko organisaation olemassaolo perustuu (Melbournen mandaatti 2012).

Epävakaissa ja kilpailuherkissä olosuhteissa osavuosikatsauksia, tilinpäätöksiä ja taloustiedotteita seuraavat muutkin kuin sijoittajat. Media, asiantuntijat ja mielipidevaikuttajat poimivat julkisista tiedotteista niin arkailut, lupailut kuin mokailutkin. Organisaatioiden on näin ollen yhä tarkemmin huomioitava yleisön moninaisuus ja niiden toisistaan poikkeavat tarpeet (Ulmer \& Sellnow 2000, 143). Tasainen, luotettava sijoittajaviestinnän virta on organisaation maineenhallintaa paljaimmillaan.

Tilanteissa, joissa omien päämäärien saavuttaminen on ensisijaisen tärkeää, käytetään usein tarkoituksenmukaisesti monitulkintaisia viestejä. Strategisesti epämääräinen viesti voi edistää organisaation kykyä luoda nahkansa uudelleen, tavoittaa mahdollisimman suuren yleisön ja mahdollistaa tulkintojen kirjon, sallien näin luovimisen hankalassakin tilanteessa. Kriisitilanteessa voidaan myös välttää aiheen lähempää tarkastelua ja ostaa lisää aikaa. (Eisenberg 1984.)

Viestinnän optimaalisen, avoimuutta korostavan mallin rinnalle kehittynyt, strategisuutta korostava lähestymistapa tarjoaa vaihtoehtoisen viestinnän taktiikan, jonka seurauksena viestinnän asian- 
tuntijat eivät välttämättä ole aina täysin avoimia ja läpinäkyviä. Tällöin viesti voi olla harkitun tulkinnanvarainen, vaikka se esitettäisiin vilpittömin aikein (Anolli, 2002; Kline, Simunich \& Weber 2008). Tällaista tahallaan epämääräistä viestintää käytettäessä puhutaan "strategisesta epämääräisyydestä". Se voidaan nähdä yhtenä tehokkaana sidosryhmäviestinnän välineenä silloin, kun viestillä pyritään tavoittamaan useita keskenään ristiriitaisia päämääriä.

Organisaatiot voivat käyttää strategista epämääräisyyttä erityisesti silloin, kun halutaan korostaa toiminnan näyttäytymistä mahdollisimman suotuisana sidosryhmille. Tämän päämäärän saavuttamiseksi strategista epämääräisyyttä voidaan käyttää joko eettisesti tai epäeettisesti. (Sim \& Fernando 2010.) Eettisyyden voidaan todeta selkeästi vaarantuvan silloin, kun viestinnän strategista epämääräisyyttä käytetään tietoisesti vastuun pakoilussa, sidosryhmien tiedottamisessa vaillinaisin tiedoin (Brewer \& Holmes, 2009) tai todisteiden vääristämisessä (Sim \& Fernando 2010; Ulmer \& Sellnow 2000). Linjanveto harhauttamisen ja strategisen epämääräisyyden välillä on siis hiuksenhieno.

\section{Sijoittajaviestintä, strateginen epä-} määräisyys ja läpinäkyvyyden dilemma

Sijoittajaviestinnän päätavoitteena voidaan nähdä luottamussuhteiden rakentamisen yrityksen ja sijoittajien välille (Mars et al. 2000). Läpinäkyvyys ja avoimuus sijoittajaviestinnässä kuvataan eettisiksi laatukriteereiksi tämän luottamuksen rakentamisessa ja sen saavuttamisessa
(Allen 2002; Dolphin 2004; Mars et al. 2000; Laskin 2007, 2009; Salvioni 2002). Laskin $(2014,210)$ toteaakin, että sijoittajaviestinnällä tulisi olla organisaatiolle nimenomaan viestinnällinen eikä pelkästään taloudellinen funktio. Myös Tuominen (2007) määrittelee sijoittajaviestinnän ensisijaiseksi tavoitteeksi nimenomaan yhteisen, pitkän aikavälin vuorovaikutuksen.

Sijoittajaviestinnän vaatimukset ovat tarkoin normitettuja, ja pörssiin listautuneet organisaatiot ovat velvoitettuja tiedottamaan sidosryhmiään tiedonantovelvollisuuden puitteissa (Arvopaperimarkkinalaki 746/2012). Eettisessä ohjeistossaan Suomen IR-yhdistys (2000) kehottaa sijoittajaviestinnän harjoittajia noudattamaan kaikessa ensisijaisesti lakia ja pitämään mielessä arvopaperimarkkinalain hengen, joka vuorostaan määrää listattuja yrityksiä läpinäkyvän ja avoimen sijoittajaviestinnän harjoittamiseen (Finanssivalvonta 2013). Strateginen epämääräisyys voidaan näin ollen nähdä sijoittajaviestinnän kontekstissa läpinäkyvyydelle vastakkaisena viestintästrategiana. Vastakkainasettelu äärimmäisen normitetun sijoittajaviestinnän ja strategisesti epämääräisen viestinnän välillä muodostaa eettisesti haastavan ristiriidan.

Sijoittajaviestinnällä ja strategisella epämääräisyydellä on molemmilla tavoitteena omien viestinnällisten päämäärien edistäminen. Siinä missä sijoittajaviestintää ohjaa aina läpinäkyvyys ja avoimuus, tarkoituksenmukaista epämääräisyyttä leimaa ensisijaisesti strategisuus. Kuvio 1 havainnollistaa etiikan roolia ja sen 


\section{O, / 65}

merkitystä näiden kahden tekijän välillä. Kun strategisuus sijoittajaviestintätilanteessa painaa enemmän kuin läpinäkyvyys, avoimuus vaarantuu ja viestinnän eettisyys saattaa kyseenalaistua. Vaikka sijoittajaviestintää säätelevät lait ja tarkoituksenmukaisesti epämääräistä viestintää sen strategiset tunnuspiirteet, todellisissa viestintätilanteissa etiikka hakee kuitenkin jatkuvasti tasapainoa.

\section{Teoriaa ja ajattelumalleja:}

Tarkoituksenmukainen epämääräisyys organisaation viestinnällisenä strategiana

Mitä ovat nämä strategisen epämääräisyyden tunnuspiirteet? Aiempi tutkimus perustuu pitkälti Eisenbergin (1984) teo- reettiseen viitekehykseen, jonka mukaan strateginen epämääräisyys on väistämätön osa organisaatioviestintää silloin, kun halutaan saavuttaa moninainen joukko vastaanottajia ja keskenään ristiriitaisia tavoitteita. Eisenberg $(1984,228)$ esittää, että näin tehdessään viestinnän asiantuntijat eivät välttämättä ole aina avoimia ja läpinäkyviä. Strateginen epämääräisyys voi Eisenbergin $(1984,227)$ mukaan olla organisaatioille tärkeä viestinnällinen resurssi, koska se lisää organisaation yhtenäistä moninaisuutta, ylläpitää olemassa olevia valta-asemia ja uskottavuutta, mahdollistaa torjumisen ja helpottaa organisationaalista muutosta.

\section{Kuvio 1.}

Etiikan rooli suhteessa sijoittajaviestintään ja strategiseen epämääräisyyteen.

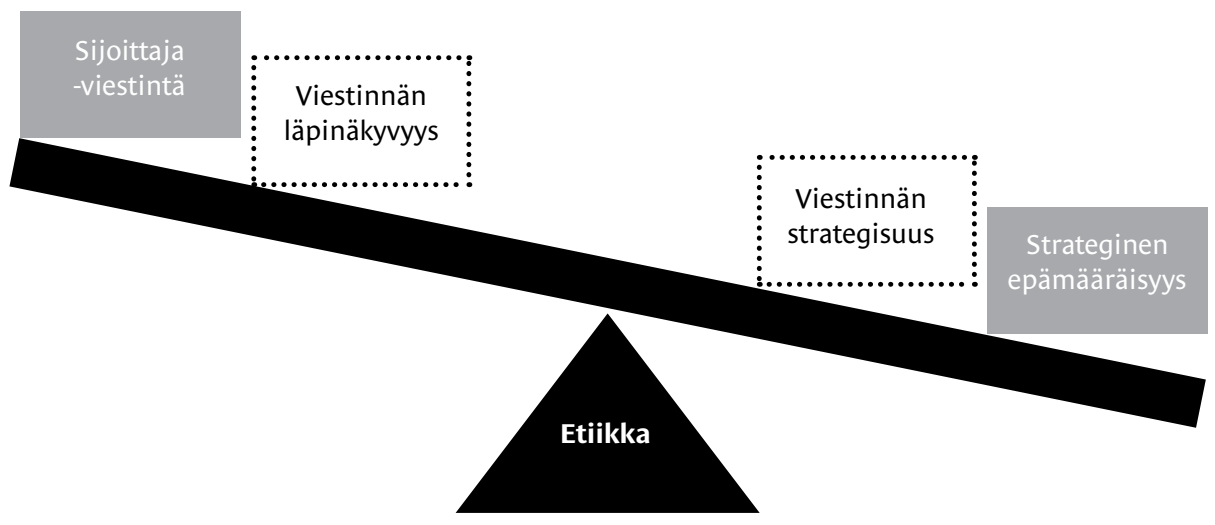


Ilmiötä on myöhemmin tutkittu myös käsitteiden epäselvä viestintä (Bavelas et al. 1990), viestinnän epävarmuus (Driskill \& Goldstein 1986) hämärä viestintä (Carter \& McCarthy 2006), estynyt viestintä (Bavelas et al. 1990) sekä viestinnän toimimattomuus (Eisenberg \& Witten 1987) näkökulmasta.

Toisistaan eriävien, abstraktien tulkintojen yhtäaikainen olemassaolo antaa organisaatiolle pelivaraa haastavissa tai jatkuvasti muuttuvissa tilanteissa. Strategisesti epämääräinen viestintä kannustaa organisaatiota uudistumaan, muuttamaan kurssiaan ja kehittymään joustavammin kohti haluttua suuntaa (Eisenberg \& Witten 1987; Carmon 2013; Ulmer \& Sellnow 2000). Strategisesti epämääräistä viestintää on todettu käytettävän viestinnällisenä taktiikkana organisaation kohdatessa ulkoisia ja sisäisiä haasteita (Kline, Simunich \& Weber 2009; Markham 1996), kriisiviestintätilanteissa (Sellnow \& Ulmer 1995; Ulmer \& Sellnow 2000), yritysten abstraktisti muotoilluissa toimintasuunnitelmissa (Carmon 2013; Eisenberg 1984) sekä organisaatioissa, joiden toimintaa leimaa jatkuva epävarmuus (Goodall, Tretheway \& McDonald 2006).

Strategista epämääräisyyttä määritellessään Eisenberg $(1984,228)$ ei kuitenkaan kannustanut vetäytymiseen avoimuudesta ja ymmärrettävyydestä. Organisaatiot kohtaavat jatkuvasti tilanteita, jotka vaativat samanaikaisesti sekä viestinnän korostettua selkeyttä että strategista epämääräisyyttä (Kline et al. 2009, 41). Koska epäselvä viestintä vaikuttaa siihen, pystyykö yleisö tekemään täsmälliseen tietoon perustuvia ja sekä itselleen että ympäristölle pitkävaikutteisia valintoja (Ulmer \& Sellnow 1997, 231), viestinnän asiantuntijan on tilanteesta riippuen valittava, turvautuako strategisen epämääräiseen vai ehdottomaan avoimuuteen pyrkivään viestintään.

Vasta kaksi vuosikymmentä myöhemmin Wexler (2009) päivitti Eisenbergin neliosaista määritelmää soveltaen sitä nimenomaan sidosryhmäviestintään (Taulukko 1). Wexler $(2009,73)$ korostaa uusissa, seitsenosaisissa kriteereissään tarkoituksenmukaisen epämääräisyyden käyttökelpoisuutta strategisessa organisaatioviestinnässä nimenomaan silloin, kun halutaan joko edistää organisationaalisia muutoksia tai kun strategisen epämääräisyyden käyttö on pitkälti organisaation johdon vallassa.

\section{Taulukko 1.}

Wexlerin (2009) päivittämät strategisen epämääräisyyden tunnusmerkit. 


\section{Strategisen epämääräisyyden tunnusmerkit (Wexler 2009)}

1. Alustavien tai tulkintaa vaativien tekstien kuten organisaation toimintasuunnitelmien ymmärtäminen

2. Ajan ostaminen painostavassa, yllättävässä tilanteessa

3. Kiistanalaisten ja mielipiteitä jakavien aiheiden käsittely

4. Organisationaalisen muutoksen mahdollistaminen

5. Organisaation suojeleminen lähemmältä tarkastelulta

6. Aiempien monitulkintaisten kommenttien torjuminen

7. Kärjistyneiden odotusten kanssa tasapainottelu organisationaalisessa kriisitilanteessa

Wexlerin päivitetyt strategisen epämääräisyyden tunnusmerkit soveltuvat hyvin kaivosyhtiö Talvivaaran sijoittajaviestinnän tarkasteluun. Talvivaaran sijoittajaviestintä on henkilöitynyt sen perustamisvuodesta 2003 lähtien pitkälti organisaation johtoon ja erityisesti toimitusjohtaja Pekka Perään. Talvivaaran metallien talteenottoa varten kehitetty biokasaliuotusmenetelmä ja tuotantomenetelmistä seuranneet ympäristöongelmat ovat herättäneet keskustelua pörssiyrityksen epäeettisestä toiminnasta, riittämättömistä varotoimenpiteistä sekä rahoittajien, työntekijöiden ja viranomaisten puutteellisesta tiedottamisesta. Viimeisen kolmen vuoden aikana etenkin sijoittajia ovat pu- huttaneet saavuttamatta jääneet tuotantotavoitteet ja tappiolliset tulokset. Suuromistajien lisäksi Talvivaaralla oli syyskuun 2013 loppuun mennessä vajaat 78000 piensijoittajaa (Pörssisäätiö 2014), mikä teki Talvivaarasta Suomen viidenneksi suosituimman kansanosakkeen. Jatkuvien vastoinkäymisten seurauksena pörssiyhtiö ajautui ensin velkasaneeraukseen ja pian sen jälkeen operatiivisen yhtiön konkurssiin marraskuussa 2014.

Strategisen epämääräisyyden käyttötavat Talvivaaran sijoittajaviestinnässä

Voidaanko Talvivaaran sijoittajaviestinnästä erottaa strategisen epämääräisyyden tunnusmerkkejä? Kysymystä pohdittiin 


\section{O, 168}

analysoimalla strategisen epämääräisyyden käyttötapoja Talvivaaran sijoittajaviestinnässä ja tutkimalla sitä, miten yritys on viestinyt sijoittajilleen suomalaisessa mediassa.

Talvivaaran sijoittajaviestintään liittyviä artikkeleita kertyi viidestä eri suomalaisesta talousalan aikakauslehdestä tai verkkomediasta (YLE, Kainuun sanomat, Taloussanomat, Talouselämä sekä Kauppalehti) yhteensä 255 kappaletta, joista voitiin erottaa 156 analyysiyksikköä. Ajankohta rajattiin koskemaan 1.1.2012-31.1.2014 välistä aikaa, jolloin Talvivaarasta käyty keskustelu on ollut yhtiön kohtaamista ongelmista johtuen runsaimmillaan. (Hara \& Nykänen 2014.) Analysoitavasta aineis- tosta nousi esiin toistuvia teemoja, jotka koodattiin käyttämällä Wexlerin (2009) seitsenosaista viitekehystä (Taulukko 2).

Kaiken kaikkiaan 97 prosentissa tutkittavista Talvivaaran sijoittajaviestinnän otannoista ilmeni strategisen epämääräisyyden käyttötapoja. Analysoiduissa otannoissa oli havaittavissa keskinäistä monitulkintaisuutta, sillä 52 prosenttia yksiköistä voitiin sovittaa useampaan kuin yhteen kategoriaan. Tulokset viittaavat strategisen epämääräisyyden käyttötapojen tulkinnanvaraisuuteen, ja niiden voidaan tältä osin sanoa olevan yhdenmukaisia aiemman tutkimuksen (ks. Eisenberg 1984; Wexler 2009) kanssa.

\section{Taulukko 2.}

Talvivaaran viestinnän strategisesti epämääräisiä lausuntoja (Hara \& Nykänen 2014.).

\section{Esimerkki}

analysoidusta lausunnosta
Strategisen epämääräisyyden kriteeri (Wexler 2009)

1. Alustavien tai tulkintaa vaativien tekstien kuten organisaation toimintasuunnitelmien ymmärtäminen

\section{Ajan ostaminen pai-} nostavassa, yllättävässä tilanteessa
Strategisen epämääräisyyden kriteerin käyttötapa

Organisaatio kertoo tulevista suunnitelmistaan usein positiivisessa sävyssä

Lauseissa esiintyy epätarkkojen faktojen esittämistä ja/tai asiasta ei tiedoteta suoralla vastauksella 


\section{O, / 69}

\begin{tabular}{|c|c|c|}
\hline $\begin{array}{l}\text { Miettinen-Lähteen mukaan tark- } \\
\text { kaan harkittuun sanamuotoiluun } \\
\text { on päädytty, koska neuvotteluissa } \\
\text { on edistytty ja yhtiössä luotetaan } \\
\text { ratkaisun löytyvän. } \\
\text { (Kainuun Sanomat 7.11.2013) }\end{array}$ & & \\
\hline $\begin{array}{l}\text { "Vaikka neljännes olikin pettymys, } \\
\text { olen kuitenkin tyytyväinen tuotan- } \\
\text { toprosessien myönteiseen kehityk- } \\
\text { seen." (Pekka Perä, Taloussanomat } \\
25.4 .2012 \text { ) }\end{array}$ & $\begin{array}{l}\text { 3. Kiistanalaisten ja mieli- } \\
\text { piteitä jakavien aiheiden } \\
\text { käsittely }\end{array}$ & $\begin{array}{l}\text { Organisaatio kiinnittää } \\
\text { huomion yksityiskohtais- } \\
\text { ten käsitteiden sijasta } \\
\text { abstrakteihin teemoihin }\end{array}$ \\
\hline $\begin{array}{l}\text { Talvivaara uskoo, että yritys- } \\
\text { saneerausmenettely ja Sotkamon } \\
\text { kaivosalueen toiminnan jatkumi- } \\
\text { nen edistävät parhaiten vesien- } \\
\text { hallintaa ja muuta ympäristön } \\
\text { puhdistamista sekä tarjoavat myös } \\
\text { parhaan mahdollisuuden säilyttää } \\
\text { arvoa eri intressitahoille. } \\
\text { (Kauppalehti 15.11.2013) }\end{array}$ & $\begin{array}{l}\text { 4. Organisationaalisen } \\
\text { muutoksen mahdollista- } \\
\text { minen }\end{array}$ & $\begin{array}{l}\text { Epämääräiset lupaukset ja } \\
\text { kommentit tulevasta, joilla } \\
\text { haetaan moninaisen kuuli- } \\
\text { jakunnan hyväksyntää }\end{array}$ \\
\hline $\begin{array}{l}\text { "Emme halua antaa tietoja yhtiön } \\
\text { tärkeimmästä ydinosaamisalueesta } \\
\text { kilpailijoille. Myös pörssisäännök- } \\
\text { set vaatisivat tietojen yhtäaikaista } \\
\text { saatavuutta kaikille omistajille”, } \\
\text { Natunen sanoo. (Taloussanomat } \\
\text { 13.8.2013) }\end{array}$ & $\begin{array}{l}\text { 5. Organisaation suojele- } \\
\text { minen lähemmältä tarkas- } \\
\text { telulta }\end{array}$ & $\begin{array}{l}\text { Huomion kiinnittäminen } \\
\text { kilpailijoihin, harhautta- } \\
\text { minen ja omien tietojen } \\
\text { luovutuskielto }\end{array}$ \\
\hline $\begin{array}{l}\text { Talvivaaran kaivosyhtiö kumoaa } \\
\text { pörssitiedotteella uutiset yhtiön } \\
\text { kassavarojen heikosta tilanteesta. } \\
\text { Myöskään väitteet suunnitteilla } \\
\text { olevista henkilöstövähennyksis- } \\
\text { tä tai lomautuksista eivät pidä }\end{array}$ & $\begin{array}{l}\text { 6. Aiempien monitulkin- } \\
\text { taisten kommenttien tor- } \\
\text { juminen }\end{array}$ & $\begin{array}{l}\text { Spekuloitujen väitteiden } \\
\text { tai mediassa käsiteltyjen } \\
\text { uutisten suora torjuminen }\end{array}$ \\
\hline
\end{tabular}




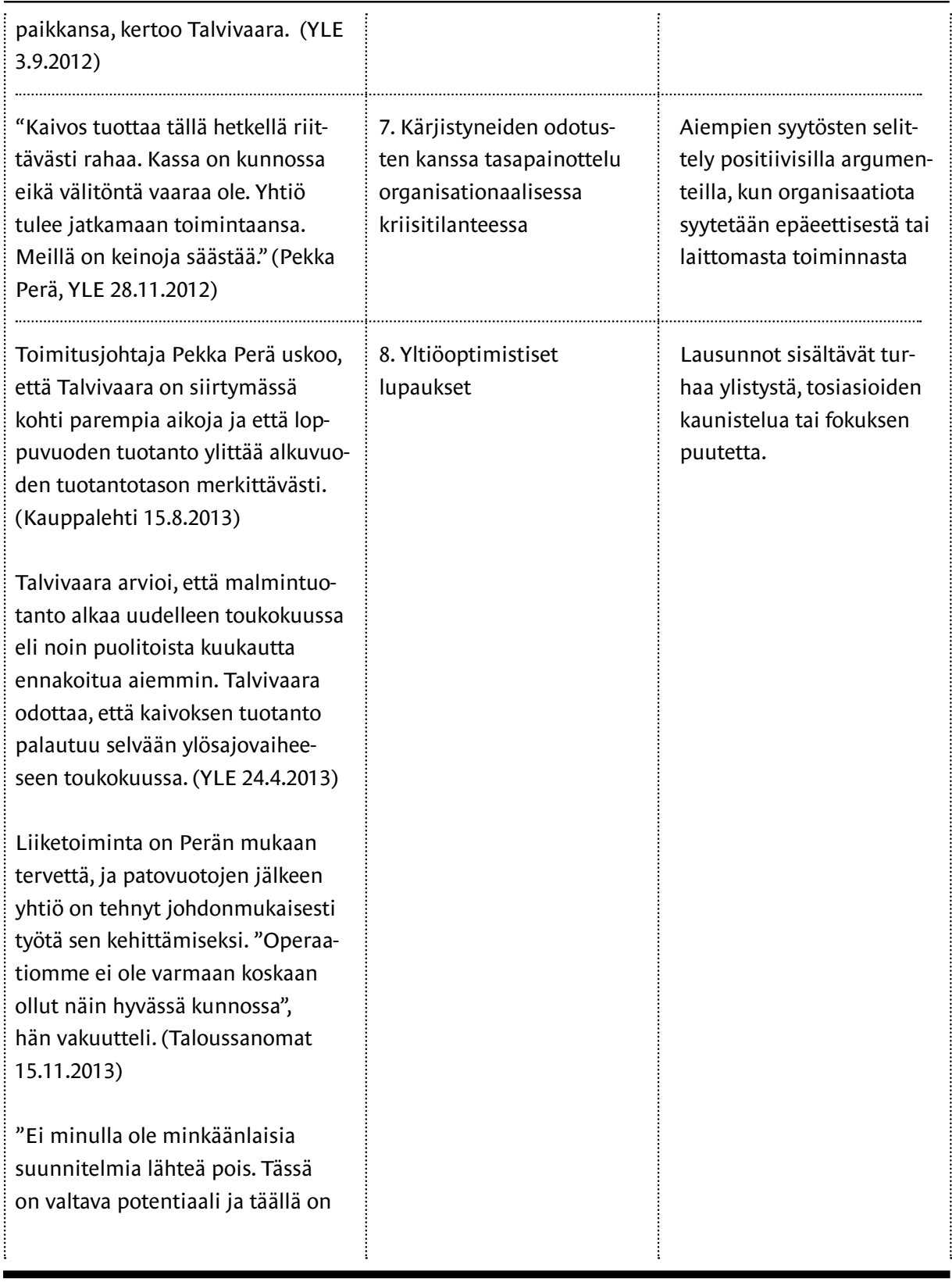




\section{O, I 71}

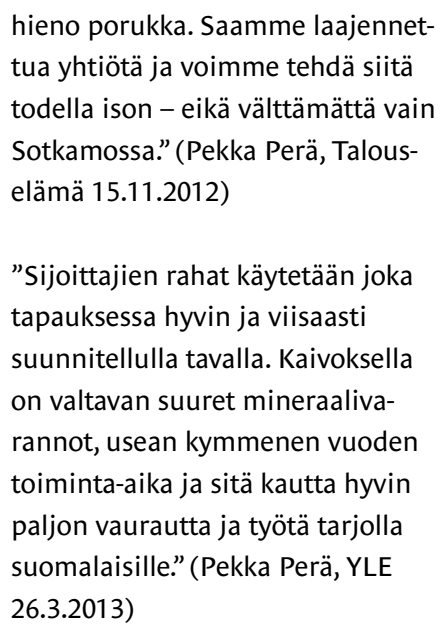

Aikaisempien kriteerien lisäksi aineistosta löytyi uusi tapa olla strategisesti epämääräinen: yltiöoptimistisia lupauksia esiintyi lähes kolmanneksessa tutkimuksen aineistosta. Talvivaaran tapauksessa yltiöoptimismi voidaan nähdä strategisen epämääräisyyden uutena organisationaalisena käyttötapana. Yltiöoptimistisia lupauksia voitiin havaita erityisesti silloin, kun organisaatio tasapainotteli sidosryhmien äärimmilleen kärjistyneiden odotusten kanssa. Wexlerin (2009) seitsemännestä kriteeristä poiketen nämä yltiöoptimistiset lausunnot eivät vastanneet kuitenkaan suoranaisesti pelkkiin syytteisiin. Sen sijaan korostetun positiivisia kommentteja esitettiin proaktiivisesti osana jatkuvaa, erityisesti sijoittajille kohdistettua sidosryhmäviestintää.
Yltiöoptimismi uutena strategisen epämääräisyyden muotona: läpinäkyvyydelle vastakkainen ilmiö?

Yltiöoptimismi esiintyi Talvivaaran sijoittajaviestinnässä erityisesti lupauksina organisaation tulevaisuuden tuotantolukujen nousemisesta ylöspäin. Tällä haluttiin mahdollisesti säilyttää sijoittajien luottamus mainekriisin keskellä ja liiketaloudellisesti äärimmäisen epävarmassa tilanteessa. Näin ollen sijoittajaviestinnän päätavoite (sijoittajien vakuuttaminen) sekä organisaation viestinnällinen pyrkimys (moninaisen kuulijajoukon puhutteleminen ja jatkuvuuden tunteen luominen hankalassa tilanteessa) yhdistyivät sijoittajille kohdistetuissa lausunnoissa yltiöoptimisiksi lupauksiksi.

Voidaanko Talvivaaran tiedottamisen sijoittajille sanoa olleen läpinäkyvää? Carroll ja Einwiller $(2014,250)$ toteavat, 
että läpinäkyvyys ja tiedottaminen eivät todellisuudessa ole suoranaisesti rinnastettavissa toisiinsa, sillä tiedottamisen tehostaminen ei automaattisesti aina lisää yhtäläistä läpinäkyvyyttä. Tiedottaminen on organisaation julkista toimintaa, jolla organisaatio tekee selväksi, että se on ottanut sidosryhmiensä tarpeet huomioon ja noudattaa asetettua tiedonantovelvollisuutta. Läpinäkyvyys ja läpinäkyvyyden signaalit edistävät taas organisaation pyrkimyksiä toteuttaa avointa viestintää käytännössä. Tällaiset läpinäkyvyyden signaalit voivat olla joko positiivisia tai negatiivisia.

Siinä missä positiiviset signaalit, kuten säädellyt taloustiedotteet, kattavat sijoittajaviestinnän verkkosivut ja aktiivinen sidosryhmäviestintä kannustavat kohti avoimuutta ja läpinäkyvyyttä, negatiiviset viestit voidaan tunnistaa siitä, että niitä täytyisi lieventää, muokata tai karsia, jotta niiden läpinäkyvyys olisi täysin ilmeistä. Negatiivisen läpinäkyvyyden viestejä esitetään usein kiristyneessä, jo kriisiä lähentelevässä tilanteessa, joka vaatii maineenhallintaa ja moninaisen yleisön vakuuttamista toiminnan jatkuvuudesta. Tällaiset negatiivisen läpinäkyvyyden signaalit sisältävät tyypillisesti epävarmuutta, turhaa ylistystä, kaunistelua tai fokuksen puutetta. (Carroll \& Einwiller 2014, 250.) Negatiivisen läpinäkyvyyden signaalien - tässä tapauksessa Talvivaaran sijoittajaviestinnässä ilmenneen yltiöoptimismin voidaan siis sanoa olevan läpinäkyvyydelle vastakkaisia ilmiöitä.

\section{Strategisen epämääräisyyden mittaaminen}

Eisenberg on todennut, että viestinnän strategioiden eettisyyttä on käytännössä haastavaa mitata. Viestintätilanteet ovat aina tilannesidonnaisia, ja niiden eettisyyden mittaus perustuu pitkälti siihen, mihin lopputulokseen valituilla viestintästrategioilla on päädytty. (Eisenberg 1982, 2006.) Viestinnän epämääräisyyden strategisen käytön on väitetty jossain määrin suorastaan vähättelevän etiikan tärkeyttä (Eisenberg \& Goodall 1993, 56). Vaikka kriitikot myöntävätkin ilmiön olemassaolon perusteet, strategisen epämääräisyyden hyödyt jäävät usein tutkimatta monien keskittyessä vain sen epäeettisiin piirteisiin (Wexler 2009, 69).

On kuitenkin todettu, että juuri viestijän harkittu epäeettisyys ja yksilön naiivius vähentävät strategisen epämääräisyyden eettistä käyttöä organisaatioissa, ei strateginen epämääräisyys itsessään (Paul \& Strbiak 1997, 156). Kiinnostavaa kyllä, Paul ja Strbiak (1997) toteavat moraaliseen johdonmukaisuuteen ja sisäistettyyn rationaalisuuteen kykenemättömien viestijöiden turvautuvan todennäköisemmin strategisen epämääräisyyden epäeettiseen käyttöön. Siinä missä moraalisen vastuunsa tiedostavat viestijät kykenevät paremmin arvioimaan omien viestintätapojensa eettisyyttä, lähtökohtaisesti eettisesti naiivit yksilöt toimivat usein etiikan rajamailla (Paul \& Strbiak 1997, 158).

\section{Miten käyttää viestinnän strategista epämääräisyyttä fiksusti?}

Strategisesti epämääräisen ja tehokkaan 
viestin tunnistaa siitä, että se on tulkinnanvarainen mutta vilpitön. Tällainen eettisesti läpinäkyvä mutta näennäisesti hämärä viesti voi edistää organisaation kykyä luoda nahkansa uudelleen ja tavoittaa mahdollisimman suuren yleisön yhdellä napakalla lausunnolla. Organisaatiot voivat hyödyntää strategista epämääräisyyttä ostaessaan aikaa kuumentuneessa tilanteessa, lanseeratessaan mottoja ja toimintasuunnitelmia tai halutessaan kasvattaa suuren joukon luottamusta organisaation toimintaan.

Jotta sijoittajien päätöksenteon tueksi olisi viipymättä tarjolla todenmukaisia ja luotettavia tietoja, strategisen epämääräisyyden vilpillinen käyttö on tärkeää tunnistaa. Hyvänä nyrkkisääntönä voidaan pitää seuraavaa: positiiviset läpinäkyvyyden signaalit kannustavat aidosti kohti avoimuutta ja läpinäkyvyyttä, kun taas negatiivisen läpinäkyvyyden viestit ovat näennäisen avoimia. Jotta niiden läpinäkyvyys olisi ilmeistä, viestiä pitäisi ensin lieventää, karsia tai muotoilla kokonaan uudelleen.

Talvivaaran sijoittajaviestinnästä voitiin erottaa uusi strategisen epämääräisyyden kriteeri: organisaation toimintaan liittyvät yltiöoptimiset lupaukset. Tämä yltiöoptimismin teema tarjoaa uuden näkökulman tarkoituksenmukaisesti epämääräisen viestinnän tutkimukseen aikana, jona tehokkaan viestinnän edellytys on usein ehdoton läpinäkyvyys. Ylipositiivisuuden ja negatiivisen läpinäkyvyyden signaalien, kuten kaunistelun ja turhan ylistämisen, on todettu olevan avoimuudelle vastakkainen ilmiö. Negatiivisen läpinäkyvyy- den tutkimusta poliittisen viestinnän ja sijoittajaviestinnän näkökulmasta ei ole kuitenkaan vielä juurikaan tehty.

Mikäli tiedotustilaisuuteen mennään strategia eikä läpinäkyvyys edellä, julkisuuteen annetut epämääräiset kommentit saattavat kääntyä itseään vastaan. Jos sijoittajaviestintätilanteessa painotetaan enemmän viestin strategisuutta kuin sen läpinäkyvyyttä, organisaation avoimuus vaarantuu ja viestinnän eettisyys saattaa kyseenalaistua. Viestinnän ammattilaiset, joilla on vahvaa osaamista sekä talouden että viestinnän saralla, tiedostavat selvimmin vastuunsa tällaisessa tilanteessa ja kykenevät parhaiten arvioimaan viestintätapojen eettisyyttä. Siksi he ovat aina tiiviisti mukana sijoittajille ja sidosryhmille kohdistetuissa tiedotustilaisuuksissa ja ohjeistavat johtoa etukäteen organisaation viestintästrategian mukaisesti. Mikäli johdon esiintyminen eroaa merkittävästi sovitusta tiedottamistyylistä, huolellisinkin viestintästrategia häiriintyy sijoittajaviestintätilanteessa.

Miten siis viestiä sijoittajille tilanteessa, jossa ehdottoman avoimen viestin esittäminen moninaiselle yleisölle ei sittenkään ole aina tarkoituksenmukaista? Harkittu epämääräisyys ei itsessään ole ratkaisu. Strategisesti epämääräisen viestin on oltava - kuten määritelmä itsessään jo lupaa - harkittu. Ylläpitääkseen sidosryhmäsuhteita ja lisätäkseen sijoittajien luottamusta organisaatioon harkitusti epämääräisen viestin on oltava eettisesti johdonmukainen. Sen käyttöä on vältettävä, mikäli riskinä on sidosryhmien tahallinen harhauttaminen. Lisäksi 


\section{0,174}

yleisöä tiedotetaan aina yhdenvertaisesti - olivat kyseessä sitten sijoittajaviestintään tottuneet suursijoittajat tai viestit toisin tulkitsevat piensijoittajat.
Taulukossa 3 esitetään tyypillisiä strategisesti epämääräisiä viestejä, joiden sisältö jää eettisesti kyseenalaiseksi, sekä ehdotetaan vaihtoehtoiset lausunnot niiden selkiyttämiseksi.

\section{Taulukko 3.}

Ehdotuksia strategisen epämääräisyyden eettiseen käyttöön.

\section{Strategisesti epämääräinen,}

negatiivisen läpinäkyvä viesti

"Toimintaamme ohjaa vakaa tahto ja näkemys tehdä asiat oikein."

"Kestävä kehitys on organisaatiossamme avainasemassa."

"Pörssiyhtiönä emme voi kommentoida."

"Pyrimme kaikessa toiminnassamme ehdottomaan avoimuuteen."

\section{Strategisesti epämääräinen,} positiivisen läpinäkyvä viesti

"Julkistamme verkkosivuillamme avoimesti tietoa kaikista toiminnoistamme."

"Kestävän kehityksen ohjelma ja konkreettiset tavoitteet esitetään toimintaperiaatteissamme."

"Kommentoimme heti, kun tiedossamme on intressisryhmiemme päätöksenteon tueksi välttämätöntä tietoa."

"Viestimme viipymättä ja luotettavasti." 


\section{Epilogi}

Helsingin Sanomat kertoi 28.4.2015 poliisin aloittaneen esitutkinnan tiedottamisrikoksesta kaivosyhtiö Talvivaarassa. Tutkintapyynnön poliisille on tehnyt Finanssivalvonta. Rikosepäily koskee yhtiön tiedottamista tuotantomääristä ja -ennusteista vuosina 2011-2013. Helsingin Sanomien saamien tietojen mukaan Finanssivalvonta katsoo, että yhtiö ei ole kertonut viivytyksettä tuotantomäärien ja -ennusteiden supistumisesta, vaikka Talvivaaran tuotantomäärät ovat kaivoksen perustamisesta lähtien olleet selvästi pienemmät kuin yhtiö on arvioinut.

\section{Lähteet}

Allen, C. E. (2002). Building mountains in a flat landscape: investor relations in the post-Enron era. Corporate Communications: An International Journal, 7(4), 206-211.

Anolli, L., Ciceri, R. \& Riva, G. (2002). Say not to say: New perspectives on miscommunication. 3. painos. Netherlands: IOS Press.

Arvopaperimarkkinalaki. 2012. 14.12.2012/746. Saatavilla verkossa: https://www.finlex.fi/fi/laki/ajantasa/2012/20120746 2.3.2015.

Bavelas, J. B., Black, A., Chovil, N. \& Mullett, J. (1990). Equivocal communication. Sage Publications. Thousand Oaks, CA.

Brewer, E. C. \& Holmes, T. L. (2009). Obfuscating the Obvious Miscommunication Issues in the Interpretation of Common
Terms. Journal of Business Communication, 46(4), 480-496.

Hara, M. \& Nykänen, A. (2014). Tarkoituksenmukainen epämääräisyys viestinnässä. Talvivaaran sijoittajaviestintä suomalaisessa mediassa. Julkaisematon.

Carmon, A. F. (2013). Is it necessary to be clear? An examination of strategic ambiguity in family business mission statements. Qualitative Research Reports in Communication, 14(1), 87-96.

Carroll, C. \& Einwiller, S. (2014). Disclosure Alignment and Transparency Signaling in CSR Reports. Hart, R. P. (Toim.): Communication and Language Analysis in the Corporate World, 249-270. Hershey, PA: IGI-Global.

Carter, R. \& McCarthy, M. (2006). Cambridge Grammar of English: A Comprehensive Guide to Spoken and Written English Grammar and Usage. Cambridge University Press.

Dolphin, R. R. (2004). The strategic role of investor relations. Corporate Communications: An International Journal, 9(1), 25-42.

Driskill, L. P. \& Goldstein, J. R. (1986). Uncertainty: Theory and practice in organizational communication. Journal of Business Communication, 23(3), 41-56. 
Eisenberg, E. M. (1984). Ambiguity as strategy in organizational communication. Communication Monographs, 51(3), 227-242.

Eisenberg, E. M. \& Witten, M. G. (1987). Reconsidering openness in organizational communication. Academy of Management Review, 12(3), 418-426.

Eisenberg, E. M. (2007). Strategic ambiguities: Essays on communication, organization and identity. Thousand Oaks, CA: Sage Publications.

Finanssivalvonta. 2013. Tiedonantovelvollisuus. Saatavilla verkossa: http://www. finanssivalvonta.fi/fi/Listayhtiolle/Tiedonantovelvollisuus/Pages/Default.aspx. 28.2.2015.

Goodall, B., Trethewey, A. \& McDonald, K. (2006). Strategic ambiguity, communication, and public diplomacy in an uncertain world: Principles and practices. Consortium for Strategic Communication, Arizona State University, 1-14.

Hara, M. \& Nykänen, A. (2014). Tarkoituksenmukainen epämääräisyys viestinnässä. Talvivaaran sijoittajaviestintä suomalaisessa mediassa. Yhteisöviestinnän kandidaatintutkielma, Jyväskylän yliopisto, Viestintätieteiden laitos. Julkaisematon.

Kelly, K. S., Laskin, A. V. \& Rosenstein, G. A. (2010). Investor relations: two-way symmetrical practice. Journal of Public Relations Research, 22(2), 182-208.
Kline, S. L., Simunich, B. \& Weber, H. (2008). Understanding the Effects of Nonstraightforward Communication in Organizational Discourse: The Case of Equivocal Messages and Corporate Identity. Communication Research, 35(6), 770-791.

Kline, S. L., Simunich, B. \& Weber, H. (2009). The use of equivocal messages in responding to corporate challenges. Journal of Applied Communication Research, 37(1), 40-58.

Laskin, A. V. (2007). The value of investor relations: A Delphi panel investigation. Gainesville, FL: The Institute for Public Relations.

Laskin, A. V. (2009). A Descriptive Account of the Investor Relations Profession A National Study. Journal of Business Communication, 46(2), 208-233.

Laskin, A. V. (2014). Investor Relations as a Public Relations Function: A State of the Profession in the United States. Journal of Public Relations Research, 26(3), 200-214, DOI: 10.1080/1062726X.2013.864244

Markham, A. (1996). Designing discourse. A critical analysis of strategic ambiguity and workplace control. Management Communication Quarterly, 9(4), 389-421.

Mars, M., Virtanen O.V. \& Virtanen, M. (2000). Sijoittajaviestintä strategisena työkaluna. Helsinki: Edita. 
The Melbourne Mandate (2012). A call to action for new areas of value in public relations and communication management. World Public Relations Forum, November 2012. Saatavilla verkossa: http://melbournemandate.globalalliancepr.org/wp-content/uploads/2012/11/Melbourne-Mandate-Text-final.pdf. 28.2.2015

Paul, J. \& Strbiak, C. A. (1997). The Ethics of Strategic Ambiguity. Journal of Business Communication, 34(2), 149-159.

Salvioni, D. (2002). Transparency culture and financial communication. Symphonya. Emerging Issues in Management, (2).

Sellnow, T. L. \& Ulmer, R. R. (1995). Ambiguous argument as advocacy in organizational crisis communication. Argumentation and Advocacy, 31(3).

Sim, A. B., \& Fernando, M. (2010). Strategic ambiguity and ethical actions. 2010 Oxford Business \& Economics Conference, 1-23. Oxford, UK: Oxford University.

Suomen IR-yhdistys. (2000). Suomen IR-yhdistyksen jäsenen ammatilliset ja eettiset periaatteet.

Tuominen, P. (2007). Investor relations: a Nordic School approach. Corporate Communications: An International Journal, 2(1), 46-55.

Ulmer, R. R. \& Sellnow, T. L. (1997). Strategic ambiguity and the ethic of significant choice in the tobacco industry's crisis communication. Communication Studies, 48(3), 215-233.

Ulmer, R. R. \& Sellnow, T. L. (2000). Consistent questions of ambiguity in organizational crisis communication: Jack in the box as a case study. Journal of Business Ethics, 25 (2), 143-155.

Wexler, M. N. (2009). Strategic ambiguity in emergent coalitions: the triple bottom line. Corporate Communications: An International Journal, 14(1), 62-77.

YLE 2013. Mot-ohjelman käsikirjoitus. Saatavavilla verkossa: http://yle.fi/aihe/artikkeli/2013/12/02/talvivaaran-legendat-kasikirjoitus 25.4.2014. 


\section{O, 178}

KUKA?

\section{Turo Uskali}

- Turo Uskali (synt. 1968) on journalistiikan dosentti Jyväskylän yliopiston viestintätieteiden laitoksella. Ennen yliopistouraansa hän oli kymmenisen vuotta toimittajan tehtävissä alueellisista sanomalehdistä valtakunnallisiin uutismedioihin. Uskali on viime vuosina tutkinut ja opettanut etenkin journalistisia innovaatioita. Hän on johtanut useita monitieteisiä Tekes-hankkeita sekä Helsingin Sanomain säätiön rahoittamia tutkimusprojekteja vuodesta 2008 alkaen. Uskali on toiminut myös vierailevana tutkijana Stanfordin ja Oxfordin yliopistoissa vuosina 2006-2008.

\section{BIG DATA JA MEDIASUHTEET: MITEN SUURET DATA-

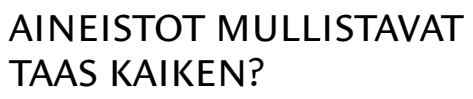

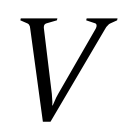

oidaan perustellusti väittää, että digitaalisten data-aineistojen merkitys yhteiskunnassa kasvaa koko ajan. Jos sosiaalisen median nopea nousu uudeksi keskeiseksi viestinnän muodoksi tuli monille yllätyksenä viime vuosikymmenen aikana, sama muutos on toistumassa nyt laajojen data-aineistojen kanssa. Datan määrän lisääntyessä koko ajan tarvitaan eri aloilla uudenlaista viestinnällistä osaamista, sillä datajournalismi on tiimityötä. Tarvitaan työkäytäntöjen kehittämistä muun muassa data-aineistojen visualisoinnin suuntaan. Uudessa ympäristössä viestinnän ammattilaiset kohtaavat sekä datajournalisteja, jotka hyödyntävät suuria aineistoja, että 
data-aktivisteja, jotka vaativat suurempaa läpinäkyvyyttä. Viestinnän ammattilaisten tulisi kehittyä dataviestijöiksi, jotka hallitsevat niin organisaation sisäistä kuin ulkoistakin datavirtaa. Suurten data-aineistojen jemmaaminen vain organisaation omaan käyttöön vaikuttaa hieman vanhanaikaiselta strategialta avoimen innovaatioiden ja joukkoistamisen maailmassa. Vaikka uutisarvoista dataa on usein vain yksinoikeudella avattu, tulevaisuuden dataviestijän tehtäviin kuuluu keskeisenä läpinäkyvyystyö, jossa putsataan suurista raakadata-aineistosta ymmärrettäviä esityksiä.

\section{Johdanto}

Journalismin taloudellinen ja teknologinen murros on jatkunut jo pitkään. Viime vuosien digitaalinen viestintäkehitys on vienyt kohti reaaliaikaisuutta. Etenkin sosiaalisen median ja verkkoanalytiikan myötä on ollut mahdollista seurata varsin yksityiskohtaisesti eri journalististen juttujen ja sisältöjen saamaa suosiota. Reaaliaikaisuus on tehostanut myös palautteen saantia etenkin mediayhtiöissä. (Stone 2014.) Viime vuosien uudet haasteet ovat koskeneet esimerkiksi natiivimainontaa, droonikameroita ja ennen kaikkea suuria data-aineistoja. Kaiken takana on lisääntynyt tieto siitä, miten lukija tai median kuluttaja käyttäytyy ja mitä hän mediasisällöiltä hakee.

Kun Internet of Things (esineiden internet) sensoreineen mahdollistaa aikaisem- paa suuremmat reaaliaikaisen datan virrat elinympäristöstämme ja droonikamerat voivat lentää vaarallisillekin kuvausalueille etsimään totuutta, on datan asema ja hallinta nousemassa viestinnässä keskiöön. Havaintopsykologinen fakta on, että ymmärrämme monimutkaisiakin asioita paremmin visualisointien kuin esimerkiksi pitkien tekstikatkelmien avulla, jolloin viestinnän ammattilaisten tehtäväksi nousee ottaa haltuun suuriakin organisaation datamääriä ja niiden avaaminen. Keskeisenä kysymyksenä on, miten parantaa dataviestintää digitaalisessa uutisekosysteemissä.

Data miningista eli datan louhinnasta on puhuttu esimerkiksi tietojenkäsittelytieteessä jo vuosikymmeniä (Fayyad et al. 1996), mutta digitaalisen datan määrän nopea kasvu ja sen laajamittainen arkistointi on noussut laajemmin julkisuuteen vasta viitisen vuotta sitten. (The Economist 2010; Hilbert \& López 2011.) Tiedon määrä on lisääntynyt valtavasti, mutta varastointikapasiteetti laahaa perässä. Näyttää siltä, että big data on viime vuosina alkanut syrjäyttää data mining -termiä, vaikka itse asiassa kyse on paljolti samasta ilmiöstä, suurten data-aineistojen haltuunotosta ja jalostamisesta tiedoksi (Stone 2014). Muun muassa amerikkalainen talouslehti Forbes on ennustanut laajojen data-aineistojen hyödyntämisen synnyttävän uuden kultaryntäyksen (Peters 2012) tai tarjoavan öljyn kaltaista uutta vaurauden lähdettä (Rotella 2012). Voidaan jopa väittää, että uudet käsitteet, kuten "big data" ja "open data" ovat jo hypetyksen kohteena. 
Datan, informaation sekä tiedon (knowledge) välinen käsitteellinen ero on usein kuvattu hierarkkisena kolmiona. Alimmalla tasolla on jäsentymätön raaka data. Mitä lähempänä kolmion huippua ollaan, sitä laadukkaammasta ja jalostuneemmasta informaatiosta on kysymys, jopa tiedosta. Viestinnän ammattilaisien tehtävänä onkin toimia kaikilla kolmion tasoilla, sekä avata raakadataa että jalostaa dataa tiedoksi ja tarjota sitä eri tarpeisiin.

Journalismin tehtävänä on jo pitkään ollut eri lähteistä saatavan ajankohtaisen tiedon analysointi, tiivistäminen ja kärjekäs esittäminen. Journalismissa on perinteisesti arvostettu myös niin sanottuja asiantuntijalähteitä, kuten viranomaisia, poliitikkoja ja yritysjohtajia. Näiden henkilölähteiden lisäksi toimittajat ovat aina olleet kiinnostuneita myös dokumenttilähteistä, joihin datajournalismin voidaan katsoa lukeutuvan. Etenkin tutkivan journalismin työmetodeihin on kuulunut aika ajoin laajojen paperisten asiakirjapinojen läpikäyminen. Digitaalisen asiakirjatallennuksen aikakaudella suurtenkin data-aineistojen läpikäynti on tullut helpommaksi ja nopeammaksi.

\section{Datajournalismin muodot}

Datajournalismi voidaan jakaa kolmeen tyyppiin:

1) päivittäinen, nopea datajournalismi

2) hidas, tutkiva datajournalismi

3) algoritmeihin perustuva reaaliaikainen datajournalismi, kutsutaan myös "robottijournalismiksi" ja "sensorijournalismiksi".
Nopea datajournalismi on mahdollista vain, jos toimituksiin saatava organisaatioiden avaama data-aineisto on valmiiksi hyvin käsiteltyä. Se ei saisi sisältää lyöntivirheitä, ja sen olisi oltava koneluettavassa muodossa. Dataviestinnän kannalta nopea datajournalismi on paras ja tehokkain yhteistyömuoto viestinnän ammattilaisten kanssa, sillä sitä kautta sekä organisaatio että media saavat nopeasti data-aineistoja julkisuuteen. Esimerkiksi kun Aller Media julkaisi keväällä 2015 Suomi24-verkkopalvelun keskustelut avoimena datana, jo pelkkä uutinen data-aineiston julkaisemisesta levisi laajasti uutismediassa (Kauppalehti 11.4.2015).

Hidas, tutkiva datajournalismi toimii pidemmällä aikajänteellä ja tarvitsee yleensä data-aineistoja, jotka eivät ole helposti saatavilla. Viestinnän ammattilaisten kannalta tutkiva datajournalismi on haastavaa, sillä se käsittelee yleensä niin sanottuja arkoja aiheita, joita organisaatio ei välttämättä halua julkaista.

Tutkiva datajournalismi perustuukin usein datavuotoihin, jotka joku organisaatiossa työskentelevistä on halunnut tehdä ja saada siten julkisuutta havaitsemalleen epäkohdalle.

Reaaliaikainen koneellinen datajournalismi vaatii saumatonta teknologista yhteistyötä dataa tuottavan organisaation ja uutistoimituksen välillä. Käytännössä dataa tuottavan organisaation välittämä tieto julkaistaan uutismedian verkkopalvelussa muutamassa sekunnissa ilman yhdenkään ihmisen väliintuloa. Uutisointi on täysin automatisoitu. Reaaliaikaiselle datajournalismille on tarvetta etenkin 
kriisiuutisoinnissa, esimerkiksi maanjäristysten yhteydessä, jolloin muutaman minuutin viiveetkin saattavat merkitä ihmishenkien menetyksiä pelastustöissä. Robottijournalismia on käytetty jo ainakin Yhdysvalloissa myös yritysten osavuosikatsausten ja urheilutulosten uutisoinnissa.

Alkeellisimmillaan datajournalistinen tuotos voi olla vaikka digitaalisella karttapohjalla esitettyä tietoa paikkakunnan rikoksista, parkkisakoista, liikenneonnettomuuksista tai vaikkapa eduskuntavaalien puoluejakautumista kaupunginosittain. Vaativimmillaan datajournalistinen juttu voi kertoa vaikkapa eduskunnan valiokuntien lobbareista, Eurooppaan salaa yrittävien maahanmuuttajien kuolemista tai veroparatiisiyhtiöiden globaalista toiminnasta. Nämä kaikki edellä mainitut datajuttuaiheet palkittiin vuosien 20132014 aikana.

On huomattavaa, että data ja informaatio voivat olla myös visuaalisessa muodossa. Käytännössä tämä on tarkoittanut myös suurten kuva- ja videoaineistoarkistojen syntyä ja niiden käyttöä datajournalistisesti. Esimerkiksi Washington Postin jutussa (6.4.2015) tehtiin yhteenvetoa noin 95000 taidemaalauksesta vuodesta 1800 lähtien. Yksi tuloksista oli, että sininen väri oli alkanut lisääntyä moderneissa taidemaalauksissa Picasson niin sanotun sinisen kauden (1901-1904) jälkeen. Tämä tieto voitiin myös visualisoida.

Voidaankin väittää, että juuri suurten data-aineistojen visualisointi on dataviestinnässä keskeisessä asemassa. Yksi hyvä visualisointi auttaa viestinnän perille menossa paljon tehokkaammin kuin pitkä teksti. Tämä korostaa tietysti graafikoiden työn merkitystä viestinnässä. (Thierauf 1999; Davenport \& Prusak 2000; Frost 2010.)

On kiinnostavaa pohtia, missä sitten on esimerkiksi big datan ja muun data-aineiston välinen raja. Columbian yliopiston datajournalismin konferenssissa lokakuussa 2014 asiantuntijat päätyivät kollektiivisesti määrittelemään rajan miljoonaan yksikköön - eli kun data-aineistossa on miljoona riviä informaatiota, se olisi big dataa. Loppujen lopuksi näin suuria data-aineistoja on ainakin toistaiseksi vielä vain harvoin saatavilla avoimena datana, eikä tällaisten aineistojen avaaminen välttämättä onnistu viestinnän ammattilaisilta vasta kuin esimerkiksi tilastokeskuksessa.

\section{Tietovuodoista datavuotoihin}

Toimituksille on aina vuodettu tietoja organisaatioista käsin. Yleensä kysymyksessä ovat olleet niin sanotut arat poliittiset aiheet. Tietovuotojen merkitys on tutkivassa journalismissa suuri, ja datajournalismillakin voidaan nähdä yhteyksiä tietovuotoihin. Jo Watergate-paljastukset, jotka johtivat Yhdysvaltain presidentin Richard Nixonin eroon vuonna 1974, perustuivat tietovuotoon. (Ettema \& Glasser, 1998.) Tietovuotajaksi osoittautui myöhemmin FBI:n varajohtaja William Mark Felt. Maailmanmaineeseen kohosivat kuitenkin the Washington Postin tutkivat toimittajat Bob Woodward sekä Carl Bernstein. Kiinnostavaa kyllä, 2010-luvulla nimenomaan tietovuotajat ovat yleensä saaneet suuremman mediahuomion kuin tietovuodoista kirjoittaneet toimittajat. 
Tämä on toisaalta uhka nykyorganisaatioiden suurien datamäärien suojelulle, mutta myös mahdollisuus yhteistyöhön. Bradley (nyk. Chelsea) Manning on tullut tunnetuksi monien keskeisten WikiLeaks-vuotojen tekijänä ja Edward Snowden puolestaan Yhdysvaltain NSA:n ja brittien vastaavan vakoilulaitoksen GCHQ tietojen sekä toimintatapojen paljastajana.

Suurten data-aineistojen avaamisella on myös juridiset perusteet. Maailman ensimmäinen tiedonvapaus- tai julkisuuslaki (Freedom of Information Act, FOIA) otettiin käyttöön Ruotsissa 1766. Tiedonvapauslain 250 -vuotisjuhlia vietetään siten ensi vuonna, 2016. Kiinnostavasti suomalaisilla oli vahva osuutensa lain synnyssä. Kokkolan kirkkoherra Anders Chydenius oli sen keskeinen ideoija, kirjoittaja ja eteenpäin viejä. (Mustonen et al. 2006.) Ruotsin esimerkin mukaan läpinäkyvyyttä tukeva julkisuuslaki on otettu käyttöön yhteensä 95 maassa. Se rinnastetaan usein jo perusihmisoikeuksiin. Esimerkiksi Yhdysvalloissa presidentti Lyndon Johnson hyväksyi lain vuonna 1966, ja Iso-Britanniassa se astui voimaan vasta kymmenen vuotta sitten, vuonna 2005. (Riekkinen \& Suksi 2014; Schudson 2014; Worthy \& Hazell 2014.)

Ei olekaan mikään ihme, että nimenomaan yhdysvaltalaiset toimittajat ovat olleet julkisuuslain innokkaimpia käyttäjiä jo vuosikymmenien ajan. Yhdysvalloista tietopyyntöjen tehtailu on vähitellen levinnyt eri puolille maailmaa, myös Suomeen, jossa Tietopyyntö-verkkosivusto avautui vuonna 2015. Sen kautta oli maaliskuuhun 2015 mennessä tehty jo lähes 100 tietopyyntöä. Pääsääntönä näyttää olleen, että eri maiden hallitukset ovat avanneet ensin lähinnä harmittomia ja hyvin usein journalistisesti käyttökelvottomia tietokantoja ja vasta journalistien tietopyyntöjen ja oikeuden päätösten jälkeen myös hieman arkaluonteisempia aineistoja, kuten esimerkiksi Isossa-Britanniassa parlamentin jäsenten kulukorvauksia. (Hewett 2013; Worthy \& Hazell 2014.) Vanhat journalistiset periaatteet pätevät osin myös datajournalismin aikakaudellakin. Aivan olennaista journalistisen julkisuuden kannalta on, että tieto tai data-aineisto on saatu yksinoikeudella eli samaa aineistoa ei ole muilla uutisorganisaatioilla.

Tässä artikkelissa pääpaino on suurissa data-aineistoissa, jotka voivat olla strukturoimattomia tai strukturoituja. Strukturoiduilla data-aineistoilla tarkoitetaan hyvin jäsenneltyjä ja järjestettyjä tietokokonaisuuksia, "big dataa". (Manyika et al. 2011; Lewis and Westlund 2014, 2.) Avoimen datan voi puolestaan määritellä dataksi, "jota voi vapaasti käyttää ja jakaa kenelle tahansa" (Open Knowledge Foundation 2012). Avoimella datalla on läheinen historiallinen yhteytensä myös avoimen lähdekoodin sovellutusten kehitystyöhön sekä tieteelliseen vertaisarviointiin, jonka tarkoituksena on varmistaa työn laatu ja luotettavuus (Lesage \& Hackett 2013, 42).

\section{Onko datan avaamisesta hyötyä?}

Avoimen datan on uskottu lisäävän taloudellista tehokkuutta ja toimeliaisuutta. Esimerkiksi Yhdysvalloissa ja Euroopan unionissa avoimen datan on toivottu syn- 
nyttävän uusia yrityksiä ja jopa teollisuudenaloja. EU:n avoimen datan politiikka lanseerattiin vuonna 2011. Euroopan komissio arvioi avoimen datan politiikan luovan vuosittain noin 40 miljardin euron arvosta uusia palveluja. (European Comission 2015; The Verge 10.4.2013.)

Taloudellisen toimeliaisuuden lisäksi globaalina tavoitteena on ollut lisätä etenkin julkishallinnon läpinäkyvyyttä avoimen data avulla. Käytännössä tämä on ollut yhä varsin takkuista. Pontevista poliittisista julkilausumista huolimatta eri maiden välillä sekä myös maiden sisällä on yhä suuria eroja avoimen datan käytännöissä. Esimerkiksi Isossa-Britanniassa on jopa pelätty, että avoimen datan politiikka on jo saattanut vähentää muun muassa asiakirjoihin tehtäviä merkintöjä. (Bowles et al 2014; Schudson 2014; Riddell 2014; Worthy \& Hazell 2014.) Käytännössä jalo tavoite hallinnon avoimuuden lisäämiseksi voi itse asiassa johtaa myös täysin päinvastaiseen vaikutukseen ylimääräisenä varovaisuutena ja tiedon pimityksenä. Kun kirjoittaja tietää, että hän voi joutua joskus julkistamaan esimerkiksi kokousasiakirjan tiedonvapauslain nojalla, pöytäkirjaan ei ehkä merkitäkään niin paljon tietoja kuin aiemmin oli tapana, ja esimerkiksi keskustelupöytäkirjat saattavat muuttua päätöspöytäkirjoiksi. Näin tavoiteltu läpinäkyvyys tiedossa saattaakin kääntyä epämääräisyydeksi.

Vaikka monet organisaatiot ovat jo Suomessakin pitkään tallentaneet tietoja digitaalisessa muodossa, niillä ei ole ollut riittävästi ammattitaitoa avoimen datan julkaisemiseen. Käytännössä julkaisemi- nen vaatii data-aineistojen siirtämisen koneluettavaan muotoon, kuten esimerkiksi Excel-tiedostoihin. Suomessa avoimen datan julkaisemisen edelläkävijöitä ovat olleet uutistietojen mukaan esimerkiksi Maanmittauslaitos ja Ilmatieteenlaitos sekä pääkaupunkiseudun suuret kaupungit (Helsinki Region Infoshare). Maailmalla edelläkävijänä on pidetty esimerkiksi Yhdysvaltain keskushallinnon ylläpitämää avoimen datan portaalia, data.gov.

Länsimaisen journalismin perustehtävänä on vallankäytön valvonta ja myös yhteiskunnan kannalta tärkeiden epäkohtien julkistaminen. Juridisesti salaisten tietojen vuotajat saattavat toiminnallaan rikkoa lakeja ja joutua siitä vastuuseen, kuten esimerkiksi Afganistanin ja Irakin sotaan liittyneiden tietojen vuotaja Manning, joka sai 35 vuoden vankeustuomion. Toimitukset, jotka julkaisivat salaista tietoa, eivät sen sijaan tehneet laittomuuksia, eikä syytteitä niitä vastaan nostettu. Toimittajien lähdesuojan tarkoituksena on varmistaa, että yhteiskunnan kannalta tärkeitä tietoja vuodetaan myös jatkossa toimituksiin. Vuotojournalismiin saattaa liittyä myös vuotajien henkilökohtaisia motiiveja, kuten pettymyksiä tai kostonhimoa. Toisinaan vuodot saattavat olla myös hämäyksiä tai suoranaisia väärennöksiä. Lähdekritiikki ja eettiset ohjeet pätevät myös datavuotojournalismiin.

\section{Data ja tekijät}

Tässä uudessa avoimen datan ympäristössä viestinnän ammattilaiset kohtaavat sekä datajournalisteja, jotka hyödyntävät suuria aineistoja, että data-aktivisteja, 
jotka käyttävät dataa omiin tavoitteisiinsa. Taulukko 1 summaa eri dataviestinnän kentän pelaajat. Datajournalistinen työ on sen verran teknisesti vaativaa, että käytännössä vain harvoin yksi työntekijä hallitsee kaikki sen tarvitsemat osa-alueet ja vaiheet. Yleensä median sisällä datatiimi koostuu toimittajasta, koodarista ja graafikosta, ja datajournalistisen työn aikaa vievin osuus on "datan puhdistaminen" eli lähinnä data-aineiston kirjoitusvirheiden löytäminen ja korjaaminen siten, että aineisto on yhdenmukaisessa kielellisessä asussa. Vasta datan puhdistamisen jälkeen voidaan tehdä luotettavaa analysointia. Dataviestintä on datajournalismia laajempi käsite, ja sitä voidaan käyttää myös muissa kuin toimitusorganisaatioissa. Keskeinen ero datajournalismiin verrattuna on, ettei dataviestinnän tarvitse olla uutisellista. Hyvä dataviestintä voi kuitenkin käyttää hyväkseen journalistisen verkkokerronnan tapoja, esimerkiksi visualisointeja ja tarinallistamista.

\section{Taulukko 1.}

Dataviestintäkentän pelaajat.

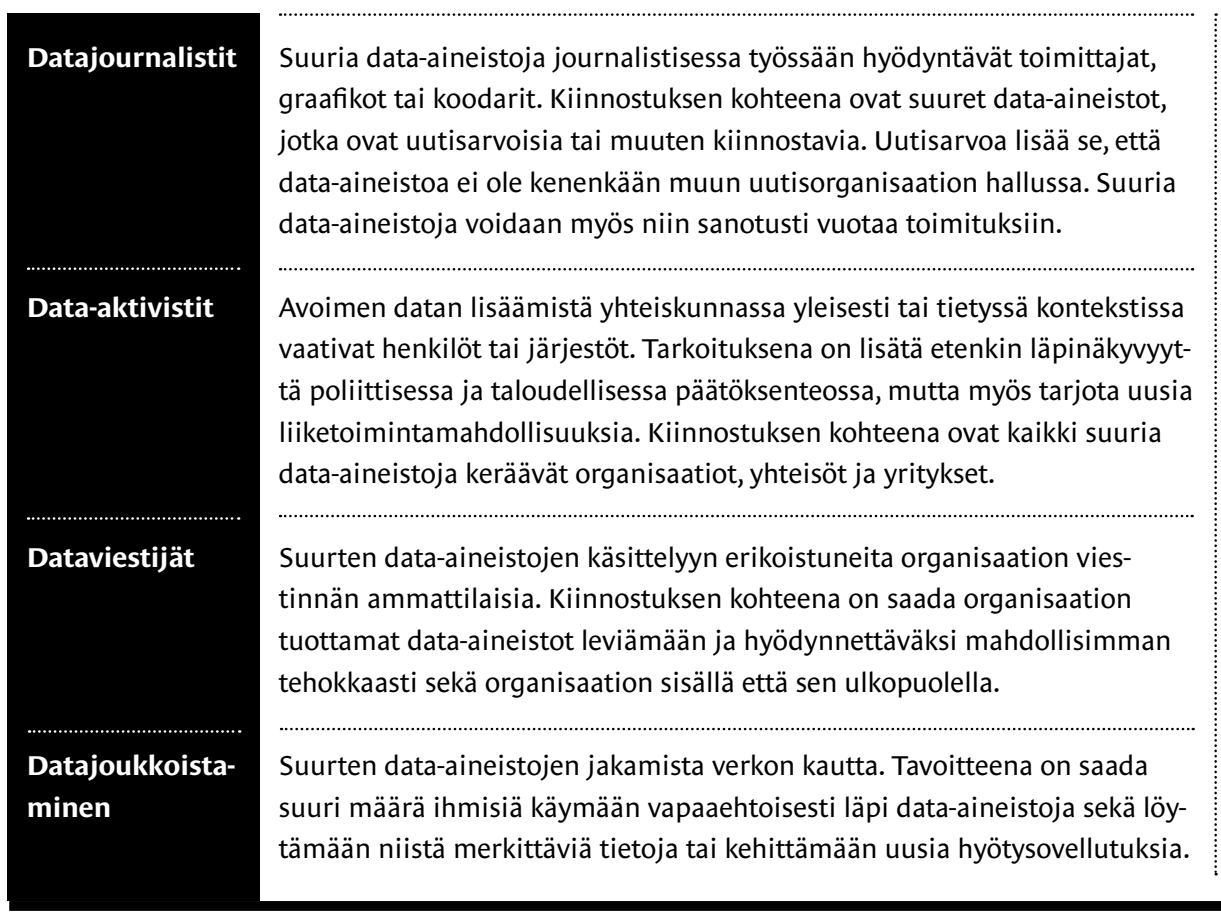


Datajournalismin ja dataviestinnän yhteydessä voidaan puhua myös huomiotyöstä ("attention work"), jolla tarkoitetaan viestinnän ammattilaisten kykyä välittää kiinnostavia sisältöjä eri yleisöille. Perinteisesti journalistien ja PR:n ammattilaisten on nähty toimivan ikään kuin samoilla markkinoilla, mutta eri lähtökohdista, jopa vihamielisinä toisilleen. On kuitenkin mahdollista löytää myös yhteisiä päämääriä ja tavoitteita näiden ammattiryhmien välillä, kuten esimerkiksi innovaatioviestinnässä ja -journalismissa on havaittu. Näyttää myös siltä, että etenkin talouden laskusuhdanteen aikoina ammattiryhmät ovat lähentyneet toisiaan (Luoma-aho et al. 2009), kaikkien toimiessa oman maineensa ja verkostojensa varassa.

Lesage ja Hackett $(2013,41-42)$ ovat käyttäneet termiä "transparency work" eli läpinäkyvyystyö, joka kuvaa hyvin myös dataviestintää. Tarkoituksena on tehdä suuristakin raakadata-aineistoista viestinnän avulla ymmärrettäviä tiedollisia esityksiä. Yksi kenties helposti lähestyttävä esimerkki on infografiikka, josta löytyy jo tuhansittain esimerkkejä internetistä. Infografiikassa suuriakin data-aineistoja voidaan tiivistää numeroin, tekstein, erilaisin graafisin esityksin sekä kuvin. Havaintopsykologinen fakta on, että ymmärrämme monimutkaisiakin asioita paremmin visualisointien kuin esimerkiksi pitkien tekstikatkelmien avulla.

\section{Datajournalismin ensiaskeleita?}

Datajournalismi ja suuriin data-aineistoihin perustuvat uudet journalistiset juttumuodot voidaan myös nähdä yhdeksi taloushaasteiden kanssa painivan journalismin "pelastajista" (Rogers 2011; Uskali 2011; Gray et al. 2012.) Perustellusti voidaankin todeta, että viestinnän alalla journalistit näyttävät toistaiseksi reagoineen ammattiryhmistä nopeimmin suurten digitaalisten data-aineistojen avaamiin uusiin mahdollisuuksiin.

Modernin datajournalismin synty voitaneen ajoittaa vuosiin 2005-2006. Esimerkiksi Jonathan Hewett $(2013,4)$ on arvioinut, että ensimmäisiä merkkejä uudenlaisesta datajournalismista oli näkyvissä jo vuoden 2005 aikana, jolloin etenkin taloustoimittajat kiinnostuivat hyödyntämään internetin avulla digitaalisia asiakirjoja. Toisaalta the Washington Postin entisen toimittajan Adrian Holovatyn Chicagocrime-verkkosivusto (2005), tietovuotosivusto WikiLeaksin perustaminen (2006), ruotsalaisen väestötieteilijän Hans Roslingin TED-luento Kalifornian Montereyssä (2006) sekä Yhdysvaltain varapresidentin Al Goren Oscar-palkittu ilmastodokumentti An Inconvenient Truth (2006) osoittivat kaikki, miten suuria datamääriä voidaan tehokkaasti ja ymmärrettävästi uutisoida, tarinallistaa ja visualisoida.

\section{Datajournalismi, tietovuodot ja wikileaks}

Varsinainen datajournalismin kansainvälinen läpimurto tapahtui kuitenkin vasta 2010, WikiLeaksin suurimpien, Afganistanin ja Irakin sotaan sekä Yhdysvaltain diplomaattipostiin liittyvien tietovuotojen uutisointien yhteydessä. Suurten tietoaineistojen hallinnointiin, käsittelyyn ja ana- 
lysointiin tarvittiin systemaattista otetta ja ammattitaitoa - datajournalistista toimitustyötä. Esimerkiksi the Guardianin datajournalisti Simon Rogers on väittänyt, että datajournalismi syntyi viimeistään vuonna 2010. Tuolloin WikiLeaksin välittämää, Afganistanin sotaan liittyvää 92201 riviä sisältävää dataa yritettiin viikkokausia turhaan mahduttaa eri puolilla maailmaa yleisessä käytössä olevaan Excel-taulukko-ohjelmaan. Senaikaiseen Excel-versioon pystyi syöttämään vain noin 60000 riviä. Tämän jälkeen taulukko-ohjelma meni aina jumiin. (Rogers 2011.)

Ongelman ratkaisemiseen tarvittiin koodaustaitoa, ja esimerkiksi the Guardianissa perustettiin WikiLeaksille vuodettuja datasettejä varten omia datavarastoja. Vasta tämän jälkeen datan käsittely oli mahdollista ja juttujen teko alkoi luonnistua. Esimerkiksi sotatiedostot olivat hyvin strukturoituja ja siten nopeasti käyttökelpoisia journalistiseen tiedon etsintään. Ajan myötä kävi ilmi esimerkiksi, miten paljon siviiliuhreja Irakin sodassa oli ollut: yli 66 000. (Rogers 2011.) Datajournalismin kehitys on siis ollut myös yhteiskunnallisen läpinäkyvyyden kehitystä tukeva asia.

Suurten data-aineistojen on toivottu auttavan myös esimerkiksi vakavien globaalien ympäristöongelmien ratkaisemisessa. Toive perustuu ajatukseen, että mitä enemmän, tarkemmin ja nopeammin toisin sanoen läpinäkyvämmin - saamme dataa ympäristöstämme, sitä enemmän tiedämme ja voimme myös tehdä parempia päätöksiä. Esimerkiksi Kööpenhaminan ilmastokokous vuonna 2009 synnytti yhteistyöverkoston ilmastonmuutoksesta kiinnostuneiden tutkijoiden ja toimittajien kesken. Sen tarkoituksena on tuottaa ja uutisoida "geodataa". (Geojournalism. org 2015)

Suurimpien tietovuotojen joukkoon voidaan lukea myös kansainväliselle tutkivien toimittajien järjestölle (ICIJ) viime vuosina vuodetut journalistisesti äärimmäisen kiinnostavat data-aineistot yritysten ja yksityishenkilöiden veroparatiisisijoituksista. Nämä tunnetaan Offshore- ja SwissLeaks-nimillä. Myös nämä tietovuodot ovat olleet data-aineiston suhteen suuria, big dataa. Avoimeen dataan verrattuna tietovuodot tarjoavat datatoimittajille ja datatoimitukselle yleensä eräänlaisen yksinoikeuden data-aineistoihin ja samalla mahdollisuuden skuuppeihin, eli jymyjuttuihin. Esimerkiksi amerikkalaisessa talousuutismediassa avointa dataa ei pidetä läheskään yhtä arvokkaana uutislähteenä kuin esimerkiksi itse hankittuja, julkisuuslain mukaisiin tietopyyntöihin perustuvia data-aineistoja tai tietovuotoja. Jos sama data-aineisto on samaan aikaan kaikkien toimitusten käytössä, sen uutisarvo saattaa vähetä, etenkin, jos joku uutistoimitus on jo ehtinyt julkaista ensimmäiset jutut aineistosta. Tietysti, jos avoimen data-aineiston tiedot ovat kiinnostavia tai yleisesti merkittäviä, myös muut toimitukset saattavat perehtyä aineistoon, mutta hyvin usein ne käytännössä tyytyvät vain referoimaan skuupin tehnyttä uutismediaa.

Vuotojournalismin saaman julkisuuden yhtenä lähtökohtana voidaan pitää, että mitä salaisemmasta ja usein myös 
arkaluonteisemmasta tietoaineistosta on kysymys, sitä enemmän se kiinnostaa tutkivia datajournalisteja. Veroparatiisiyhtiöt, eri maiden tiedustelulaitokset tai sotavoimat eivät perinteisesti ole pitäneet kovin suurta ääntä omasta toiminnastaan, joten jos näitä organisaatioita koskevia tietoja yhtäkkiä tulee toimituksiin, on selvää, että uutisointi on näyttävää ja pitkäaikaista.

\section{Data-aktivistit ja joukkoistaminen}

Datajournalistit ovat useissa maissa tehneet yhteistyötä avoimen datan aktivistien kanssa. Yhteisenä pyrkimyksenä on ollut yhdistää toimittajien ja aktivistien voimat ja saada ennen kaikkea uusia julkishallinnon data-aineistoja julkisuuteen. (Lesage \& Hackett 2013, 43.) Open Knowledge Foundation ja Sunlight Foundation ovat kansainvälisesti tunnetuimmat avoimen datan aktivistiorganisaatiot. Myös Suomeen datajournalismi rantautui ainakin osaksi avoimen datan aktivistien kautta vuosien 2011-2012 aikana. Samaan tapaan kuin avoin data korostaa läpinäkyvyyden merkitystä yhteiskunnassa, korostuu läpinäkyvyys myös aktivistien vaatimuksissa ja datajournalismissa.

Läpinäkyvyysvaatimusten mukaan journalistisessa jutussa olisi kerrottava datan hankintatapa, datan käsittelyn metodit sekä analyysimenetelmät. Ehkäpä ensimmäistä kertaa journalismin historiassa myös toimittajilta edellytetään omasta työstään näin suurta työstöprosessin läpinäkyvyyttä ja avoimuutta. (Lesage \& Hackett 2013.) Ideaalin datajutun yhteydessä julkaistaan myös koko käytetty data-ai- neisto koneluettavassa muodossa, jolloin muut toimittajat ja toimitukset voivat tarpeen tullen tarkistaa ja myös jatkojalostaa data-aineistoa omiin juttuihinsa. (Rogers 2011; Lesage \& Hackett 2013.) Käytännössä kokonaisten datasettien avoin jakaminen datajuttujen yhteydessä on ollut yhä varsin harvinaista, vaikka ajoin pyrkimystä siihen suuntaan onkin.

Myös joukkoistamista eli yleisön saamista talkootöinä mukaan journalististen juttujen tekoon on kokeiltu datajournalismissa. Tähän mennessä tunnetuimmat tapaukset liittyvät jo aiemmin mainittuun brittiläisten parlamentin jäsenten kulukorvauksiin (MP's Expenses) sekä Lontoon mellakoihin (Reading the Riots). (Lesage \& Hackett 2013, 40; Vehkoo 2013, 6-7.) Molemmissa tapauksissa tuhannet ihmiset avustivat the Guardianin toimittajia. Jälkimmäisessä juttuprojektissa oli mukana myös akateemisia tutkijoita, The London School of Economics and Politicsista.

Tähän asti tunnetuin kotimainen datajournalistinen joukkoistaminen perustui pankkien omaisuudenhoitajien ja meklarien tekemiin kauppa-aineistoihin. Helsingin Sanomat kävi vuonna 2011 ensin itse läpi aineistoa ja teki sen pohjalta uutisia. Lopulta lehti päätti kuitenkin joukkoistaa laajan data-aineiston lukijoilleen, jotka tekivätkin uusia uutislöytöjä, yhteensä noin 50. Lukijoiden avulla selvisi muun muassa, että monet meklarit ja omaisuudenhoitajat olivat tehneet laittomia ja epäeettisiä kauppoja sekä saaneet ylimääräisiä bonuksia verottomasti. (Vehkoo 2013, 15-21.) 


\section{Datapelit}

Suurin osa datajournalistisista jutuista tarjoaa jonkinasteista interaktiivisuutta, vaikka kokonaisia data-aineistoja onkin yhä vain harvoin tarjolla. Verkkojutun lukija voi usein itse klikata esiin häntä itseään eniten kiinnostavia teemoja ja yksityiskohtia. Useat uutistoimitukset ovatkin kertoneet, että datajournalistiset verkkojutut ovat erittäin luettuja ja lukijat viettävät niiden parissa keskimääräistä enemmän aikaa.

Monissa luetuimmissa datajutuissa on myös pelillisiä piirteitä, kuten esimerkiksi The New York Timesin vuoden 2013 suosituimmassa jutussa, joka oli murretesti. Samankaltainen murretesti julkaistiin myöhemmin myös Helsingin Sanomien verkkosivuilla. Hyvin usein datajournalistit saavatkin juttuideoitaan muiden tekemistä jutuista. Näyttää vahvasti myös siltä, että 2014 oli nimenomaan verkkotestien läpimurtovuosi. $\mathrm{Ne}$ toivat kaivattua klikkivirtaa uutismedian, etenkin Yleisradion ja Helsingin Sanomien verkkosivuille. Myös eduskuntavaalit keväällä 2015 inspiroivat monia vaaliteemaisia pelisovellutuksia perinteisistä vaalikoneista puoluejohtajien ajatustenlukupeliin. (https://vaalikoneet.zef.fi/eduskuntavaalit/.)

Kiistatta yksi datajournalismin keskeisistä vahvuuksista on, että ainakin teoriassa sen avulla voidaan saada haltuun kokonaisia lähdeaineistoja, esimerkiksi koko maan kattavia tietoja eri alueilta. Yleensähän journalismissa käytetään vain varsin suppeaa lähdepohjaa, esimerkiksi joitakin asiantuntijoiden haastatteluja. Voidaan kriittisesti kysyä, onko tietopohja tällöin liian sattumanvaraista, vain anekdootin tasoista. Muun muassa Lesagen \& Hackettin $(2013,43)$ mukaan datajournalismi saattaa olla ainakin jollain tasoilla täydempää ja myös objektiivisempaa kuin esimerkiksi yksittäisen journalistin keräämä aineisto ja tulkinnat.

Datajournalismiin, kuten myös kaikkeen muuhunkin dataviestintään, pätevät yleiset eettiset säännöt. Dataviestinnässä on otettava erityisesti huomioon, että vaikka data-aineistossa olisi yksityiskohtaisia henkilö- ja osoitetietoja, niitä ei automaattisesti sellaisenaan saa julkaista. (Bradshaw 2013.) Etenkin yksityisyyden suojaa on kunnioitettava. Yhdysvalloissa käynnistyi ensimmäinen laaja eettinen keskustelu sen jälkeen, kun eräs itärannikon paikallislehti julkaisi paikkakunnan kaikkien aseluvan haltijoiden tiedot karttapohjalla. Datajutun julkaiseminen ajoittui Sandy Hookin kouluampumistragedian jälkeiseen aikaan vuonna 2012. (Culver 2013.) Selkeä yksityisyyden loukkaus olisi esimerkiksi, jos julkaistaisiin tietoja kaikista suomalalaisista, joilla on aseenkantolupa tai vaikkapa yksityiskohtaisia sairaustietoja.

\section{Dataviestintää käytännössä}

Voidaan perustellusti väittää, että digitaalisten data-aineistojen merkitys kasvaa koko ajan yhteiskunnassa. Digitaalisen datajournalismin lyhyt historia osoittaa, että uusia datakerronnan tapoja kehitellään koko ajan. Kuvaavaa on, että datajournalismin kansainvälisessä palkinnossa (GEN) harkitaan mobiilikategorian 
mukaanottoa. Dataviestintä onnistuu vain, jos tekijöiden tilastotieteellinen tietämys data-aineistojen analysoimisessa on kohdallaan. Dataviestintä ja datajournalismi mahdollistavat myös tulevaisuuden ennakoinnin: Maailman parhaiten palkattu datajournalisti, amerikkalainen Nate Silver, on taustaltaan - tilastotieteilijä. Hän nousi maailmanmaineeseen ennustamalla the New York Timesin blogissaan Yhdysvaltain presidentinvaalien lopputulokset useaan kertaan lähes täysin oikein, ja paljon paremmin kuin uutismedian perinteisesti suosimat vaaligallupit tai vaaliasiantuntijat. Nykyään Nate Silver työskentelee amerikkalaisen urheilukanavan ESPN:n datajournalismiin erikoistuneen blogin FiveThirtyEightin päätoimittajana. Nate Silverin esimerkin siivittämänä Yhdysvaltoihin on perustettu useita datajournalismiin erikoistuneita blogeja ja muita verkkopalveluja, kuten New York Timesin the Upshot ja Vox.

Suomessa johtavia datajournalismin tekijöitä ovat Helsingin Sanomien datadeski ja Yleisradion plusdeski, joka jakaantui kahtia vuoden 2015 alun organisaatiouudistuksessa. Osa plusdeskin toimittajista, koodareista ja graafikoista jäi Yhteiskunta-toimitukseen ja osa siirtyi tukemaan ulkomaanuutisiin keskittyvän Maailma-toimituksen työtä. Lisäksi Yleisradion ruotsinkielisellä puolella on pieni datajournalismin yksikkönsä. Myös Suomen Kuvalehdessä on tehty aika ajoin näyttävää datajournalismia.

Miten paljon laajoja data-aineistoja eri yrityksissä ja muissa organisaatioissa on kyetty aidosti hyödyntämään, on jossain määrin jäänyt hämärän peittoon. Jotain kuitenkin kertoo se, että aika ajoin suuret yritykset, kuten Nokia, ovat avanneet patenttejaan ja tarjonneet niitä kenen tahansa hyödynnettäviksi. Suurten data-aineistojen jemmaaminen vain omaan käyttöön vaikuttaa hieman vanhanaikaiselta strategialta avoimen innovaatioiden (Chesbrough 2003) ja joukkoistamisen maailmassa (Aitamurto 2014). Dataviestinnällä onkin organisaatioissa kaksi tehtävää, sekä sisäinen että ulkoinen. Seuraavan sivun kuvio summaa nämä. 


\section{Kuvio 1.}

Dataviestinnän tehtävät organisaatiossa.
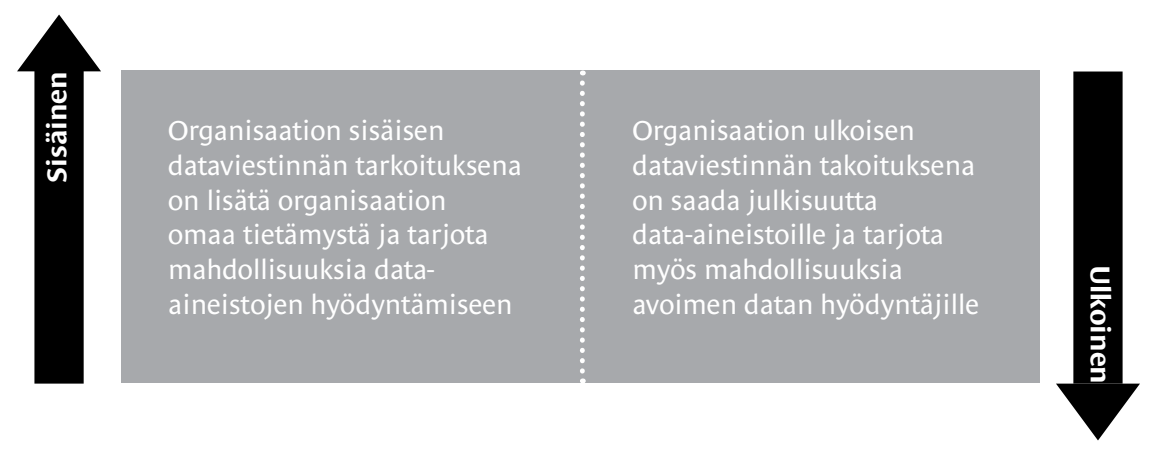

Dataviestinnässä pitäisikin korostua avoimuus ja ulospäin suuntautuneisuus, jopa läpinäkyvyys. Dataviestinnässä käytössä ovat luonnollisesti kaikki yleiset viestintäkanavat perinteisestä uutismediasta uusiin sosiaalisen ja mobiiliviestinnän sovellutuksiin. Viestintästrategiassa olisi hyvä miettiä, mitkä data-aineistot voisivat kiinnostaa eri sidosryhmiä ja mitä kautta nämä ryhmät olisivat parhaiten tavoitettavissa. Käytännössä dataviestinnässä ollaan kuitenkin vasta alkuvaiheessa, ja hyvän dataviestinnän käytännöt sekä pelisäännöt vaativat vielä kehitystyötä.

Organisaatioiden dataviestintä voi olla joko oma-aloitteista tai tietopyyntöihin reagoivaa. Avoimuus- ja läpinäkyvyysperiaate toteutuvat luonnollisesti paremmin proaktiivisessa dataviestinnässä. Molemmissa tapauksissa tietoaineistojen julkistaminen voi kuitenkin lopulta johtaa organisaation kannalta tärkeisiin ja kiinnostaviin lopputuloksiin. On oletettavaa, ettei kaikilla organisaatioilla välttämättä ole itsellään riittävästi omia resursseja kaikkien data-aineistojensa analyysiin, saati sitten tehokkaaseen dataviestintään. Hieman lisää julkisuutta voi saada, jos tarjoaa (tai vuotaa) kiinnostavaa data-aineistoa ensin vain yhdelle joukkoviestimelle. Perinteisesti esimerkiksi toimitusten johtavat tutkivat journalistit ovat saattaneet saada aika ajoin erikoispostilähetyksiä ja vinkkejä. Heihin ja heidän työnsä jälkeen luotetaan.

Data-aineiston julkaiseminen avoimena datana ja sen analyysin joukkoistaminen voi olla kaikkien kannalta paras ratkaisu. Etenkin julkishallinnossa hallinnon läpinäkyvyyden periaate toteutuu varsin tehokkaasti nimenomaan suuria data-aineistoja julkaisemalla. Datajournalistien 
ja muiden avoimesta datasta kiinnostuneiden henkilöiden tekemät tekstiyhteenvedot ja visualisoinnit saattavat paljastaa mielenkiintoisia asioita, kuten esimerkiksi taloudellista väärinkäyttöä. Hyvin usein organisaatioiden edustajat ovatkin perustelleet avoimen datan julkaisemista sillä, että myös he itse tarvitsevat jalostuneempaa tietoa ja palautetta omasta toiminnastaan.

Paul Bradshaw on aiheellisesti muistuttanut The Data Journalism Handbookin (2012) johdannossa: "Kuten mikä tahansa lähde, sitä (data-aineistoa) pitäisi käsitellä skeptisesti; ja kuten mitä tahansa työkalua käytettäessä, meidän tulisi olla tietoisia sen rajoituksista." Laajatkaan data-aineistot eivät välttämättä ole täydellisiä tai kerro kaikkea. Niiden kokoamiseen ja tallentamiseen voi liittyä monia inhimillisiä virhemahdollisuuksia. Niitä voidaan myös tarkoituksellisesti manipuloida ja väärentää. Peruskriittisyys on hyvä muistaa aina, kun käyttää lähteenään suuria data-aineistoja. On kuitenkin varmaa, että esimerkiksi datajournalismin nykyisistä parhaista työkäytännöistä löytyy runsaasti käyttökelpoisia malleja ja ideoita myös organisaatioviestinnän ammattilaisille. Alla on listattuna viisi datajournalismin työkäytännöistä juontuvaa perusneuvoa, joista voisi lähteä liikkeelle oman dataviestintäkoulutuksen ja datastrategian kehittämiseksi.

1) Etsi ja tunne organisaatiosi dataaineistot. Yleensä tietokannoista ja -järjestelmistä on olemassa niin sanotut rekisteriselosteet, joiden pitäisi kertoa data-aineistojen sisällöistä. Julkisuuslain mukaan nämä rekisteritiedot olisi kerrottava aina myös tietopyynnön tekijälle.

2) Opettele taulukkolaskentaohjelmien käyttöä. Datan käsittelyn perustaitoihin kuuluu taulukkolaskentaohjelmien hallinta (esimerkiksi Excel tai Googlen vastaavat ohjelmat). Monet edistyneemmätkin datajournalistit ovat kertoneet, että heidän työnsä perustuu edelleen pitkälti taulukkolaskelmien käytölle.

3) Muokkaa data-aineisto koneluettavaan muotoon. Dataviestinnän näkökulmasta on erittäin tärkeää, että suuret data-aineistot pystytään muokkaamaan koneluettavaan muotoon eli esimerkiksi Excel-tiedostoiksi. Käytännössä etenkin julkishallinnossa on paljon data-aineistoa tallennettuna pdf-muodossa, joka ei sellaisenaan kelpaa dataviestinnän sisällöksi. Pdf-muotoinen data-aineisto on ensin muunnettava johonkin taulukkolaskentaohjelmaan sopivaksi. Myös verkkosivuilla julkaistua data-aineistoa kannattaa muuntaa koneluettavaan muotoon. Tätä kutsutaan datan skreippaamiseksi (scraping). Skreippaamista varten on olemassa useita verkkotyökaluja.

4) Puhdista data-aineistoa. Valtaosa raakadata-aineistoista on aluksi niin sanottua likaista dataa. Datan 
puhdistaminen eli käytännössä datan tallentamisessa tapahtuneiden lyöntivirheiden korjaaminen ja data-aineiston kriittinen sisällön laadun arviointi on olennaisen tärkeää laadukkaassa dataviestinnässä. Likaisen datan puhdistaminen saattaa viedä jopa yli 80 prosenttia dataviestintään käytetystä ajasta. Valmiiksi puhdistettujen ja kiinnostavien datasettien tarjoami nen toimituksiin voisi olla uusi, tehokas viestinnän muoto - etenkin, koska pienet toimitukset eivät useinkaan pysty itse tekemään datan puhdistusta ja samalla data journalismia resurssien vähäisyyden vuoksi. Suomessa etenkin Helsinki Region Infoshare ja Open Knowledge Foundation voivat antaa hyviä neuvoja dataviestinnän aloittamisessa.

5) Visualisoi data-aineistoja. Datan visualisointi ja tarinallistaminen lisäävät data-aineistojen kiinnosta vuutta. Data-aineistojen visualisointeihin on olemassa monia ilmaisia ja helppokäyttöisiä tietokoneohjelmia.

\section{Näistä voit aloittaa}

Kuten yllä olevasta käy ilmi, dataviestinnässä ei välttämättä tarvita aluksi lainkaan koodaus- eli ohjelmointitaitoa. On kuitenkin eduksi, jos dataviestijä tuntee koodareita ja saa tarpeen tullen myös koodausapua. Kuten aiemmin jo on mainittu, dataviestintä vaatii useimmiten tiimityötä ja eri erikoisalueiden hyvää hallintaa. Lisäksi kannattaa liittyä sosiaalisen median data-aiheisiin ryhmiin. Esimerkiksi monet Facebookin aktiiviset datajournalismiin ja avoimeen dataan erikoistuneet kansainväliset ja kansalliset ryhmät toimivat tehokkaina, jopa reaaliaikaisina, uuden tiedon jakajina sekä helpdeskeinä. Sosiaalisen median ryhmät toimivat myös verkostoitumisen sekä oman työn markkinoinnin apuna.

1) Gray, J., Bounegru, L. \& Chambers, L. (toim.) (2012). The Data Journalism Handbook. EJC: Brussels. http://data journalismhandbook.org/1.0/en/.

2) Bradshaw, P. (2013a). Scraping for Journalists. Lean Publishing. https://le anpub.com/scrapingforjournalists.

3) Bradshaw, P. (2013b). Data Journalism Heist. Lean Publishing. https://leanpub. com/DataJournalismHeist.

\section{Lähteet}

Aitamurto, T. (2014). Collective Intelligence in Open Journalism: Power, Knowledge and Value. Tampere: University of Tampere.

Bowles, N., Hamilton, J. T. \& Levy, D.A.L. (2014). Introduction. Bowles, N., Hamilton, J. T. \& Levy, D.A.L.: Transparency in Politics and the Media, xi-xxiii. Reuters Institute for the Study of Journalism; London: I.B.Tauris. 
Bradshaw, P. (2012). Introduction: What is Data Journalism? Gray, J., Bounegru, L. \& Chambers, L. (toim.). The Data Journalism Handbook. Brussels: EJC. http://datajournalismhandbook.org/1.0/en/.

Bradshaw, P. (2013). Ethics in Data Journalism: accuracy. Online Journalism Blog. http://onlinejournalismblog. com/2013/09/13/ethics-in-data-journalism-accuracy/, 16.3.2015.

Campbell, D. (2013). How ICIJ's Project Team Analyzed the Offshore Files. ICIJ. org, http://www.icij.org/offshore/how-icijs-project-team-analyzed-offshore-files, 19.3.2015.

Chesbrough, H. W. (2003). Open Innovation: The new imperative for creating and profiting from technology. Boston: Harvard Business School Press.

Culver, K. (2013). Where the Journal News Went Wrong in Mapping Gun Owners. Mediashift. Pbs.org, http://www.pbs.org/mediashift/2013/02/where-the-journal-newswent-wrong-in-mapping-gun-owners053/, 17.3.2015.

Ettema, J. S. \& Glasser, T.L. (1998). Custodians of conscience: investigative journalism and public virtue. Columbia University Press, New York.

European Comission (2015). Digital Agenda: Turning government data into gold, http://europa.eu/rapid/press-release_IP-111524_en.htm?locale=en, 14.3.2015.
Fayyad, U., Piatetsky-Shapiro, G. \& Smyth P. (1996). From Data Mining to Knowledge Discovery in Databases. AI Magazine 17(3), $37-54$.

Friedersdorf, C. (2014). The Latest Snowden Leak Is Devastating to NSA Defenders. The Atlantic. http://www.theatlantic. com/politics/archive/2014/07/a-devastating-leak-for-edward-snowdens-critics/373991/, 17.3.2015.

Geojournalism.org. 2015. http://geojournalism.org/, haettu 14.3.2015.

Gray, J. Bounegru, L. \& Chambers, L. (toim.) (2012). The Data Journalism Handbook. EJC: Brussels. http://datajournalismhandbook.org/1.0/en/

Hilbert, M \& López, P. (2011). The World's Technological Capacity to Store, Communicate, and Compute Information. Science 332(6025), 60-65.

ICIJ.org. 2015. http://www.icij.org/

Kuutti, Heikki. (2011). Julkisuuslaki. Jyväskylä: Jyväskylän yliopisto.

Lewis, S. C. \& Westlund, O. (2014). Big Data and Journalism. Digital Journalism, DOI: 10.1080/21670811.2014.976418.

Lesage, F. \& Hackett, R. A. (2013). Between Objectivity and Openness - The Mediality of Data for Journalism. Media and Communication 1(1), 29-50. 
Luoma-aho, V., Uskali, T. \& Weinstein, A. (2009). 14. Pitfalls of Attention Work in the Innovation Ecosystem. Stanford University 2009. Innovation Journalism 6(5). http://www.innovationjournalism.org/ archive/injo-6-4.pdf.

Manyika, J., Chui, M., Brown, B., Bughin, J., Roxburgh, C. \& Hung Byers, A. (2011). Big data: The next frontier for innovation, competition, and productivity. McKinsey Quarterly, http://www.mckinsey.com/insights/ mgi/research/technology_and_innovation/ big_data_the_next_frontier_for_innovation, 16.3.2015.

Morozov, E. (2011). The Net Delusion. The Dark Side of Internet Freedom. New York: Public Affairs.

Mustonen, J. (toim.) (2006). The World's First Freedom of Information Act. Anders Chydenius Foundation: Kokkola.

Oxford English Dictionary. 2015. http:// www.oed.com/.

Peters, B. (2012). The Big Data Gold Rush. Forbes.com, http://www.forbes.com/sites/ bradpeters/2012/06/21/the-big-data-goldrush/, 16.3.2015.

Rogers, S. (2011). Facts are sacred: The power of data. Guardian shorts. London: The Guardian.

Rotella, Perry. (2012). In Data the New Oil. Forbes.com, http://www.forbes.com/sites/ perryrotella/2012/04/02/is-data-the-new- oil/, 16.3.2015.

Riddell, P. (2014). Impact of Transparency on Accountability. Bowles, N., Hamilton, J. T. \& Levy, D.A.L. (toim.): Transparency in Politics and the Media, 19-30. Reuters Institute for the Study of Journalism; London: I.B.Tauris.

Schudson, M. (2014). Origins of the Freedom of Information Act in the United States. Bowles, N., Hamilton, J. T. \& Levy, D.A.L. (toim.): Transparency in Politics and the Media 1-18. Reuters Institute for the Study of Journalism; London: I.B.Tauris.

Stone, M. L. (2014). Big Data for Media. Oxford: Reuters Institute for the Study of Journalism. The Verge. 10.4.2013. EU Open Data law set to speed the development of Europe-wide services:Could generate an extra $\$ 52$ billion for the EU each year, http://www.theverge. com/2013/4/10/4208196/eu-open-data-lawpassed-by-council,14.3.2015.

Uskali, T. (2011). Innovaatiot ja journalismi. Helsinki: Infor.

Worthy, B. \& Hazell, R. (2014). The Impact of the Freedom of Information Act in the UK. Bowles, N., Hamilton, J. T. \& Levy, D.A.L. (toim.): Transparency in Politics and the Media, 31-48. Reuters Institute for the Study of Journalism; London: I.B.Tauris. 


\section{O, / 95}

\section{LAITETAAN YHDESSÄ SISÄLTÖSITÖIHIN}

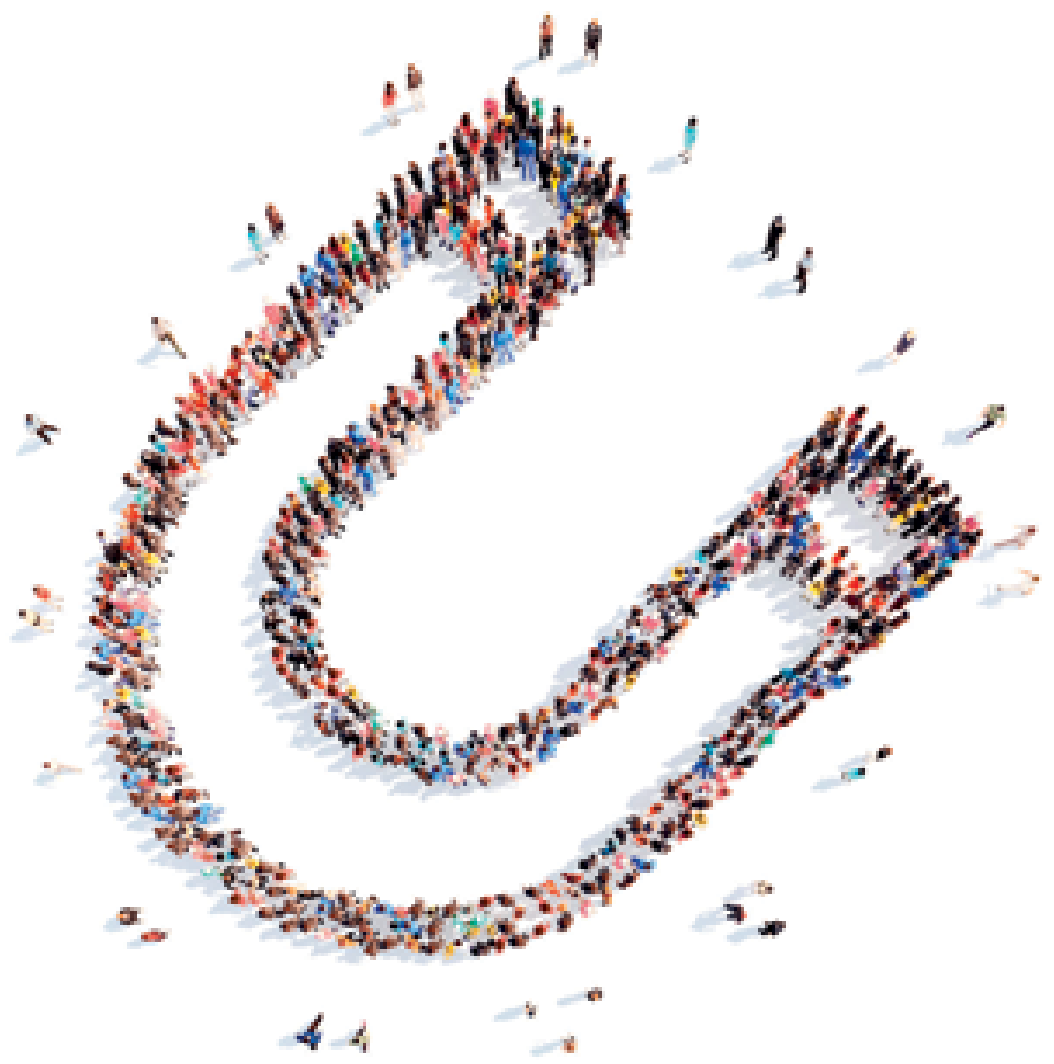

MONIKANAVAISEN SISÄLLONTUOTANNON VAIKUTUKSET OVAT MITATTAVISSA ASIAKKAIDEN JA MUIDEN SIDOSRYHMIEN TIEDOISSA, ASENTEISSA JA KÄYTTÄYTYMISESSÄ. 


\section{O, / 96}

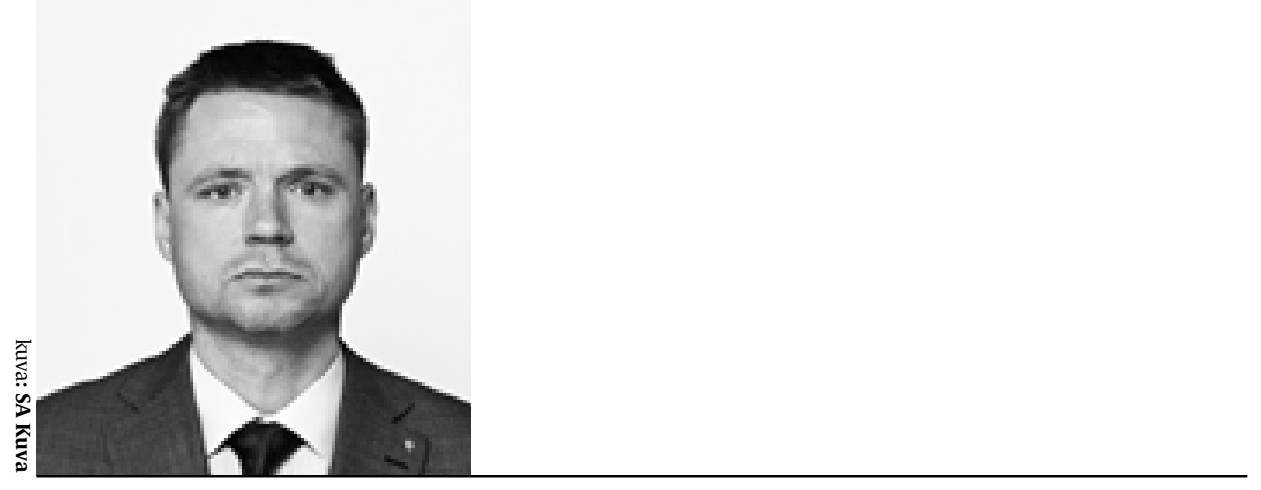

KUKA?

Aki-Mauri Huhtinen

- Aki-Mauri Huhtinen (synt. 1966) on johtamisen sotilasprofessori Maanpuolustuskorkeakoulun Johtamisen laitoksella. Huhtinen on väitellyt vuonna 1996 Tampereen yliopistossa teoreettisesta filosofiasta ja valmistunut Maanpuolustuskorkeakoulun Yleisesikuntaupseerikurssilta vuonna 2000. Huhtinen on ollut vierailevana professorina Edith Cowan yliopistossa Australiassa 2006-2007 sekä vierailevana tutkijana Baltic Defence Collegessa 2014. Huhtinen palveli kriisinhallintaoperaatiossa Afganistanissa 2013-2014. Huhtinen on Helsingin, Lapin ja Tampereen Teknillisen yliopiston dosentti.

INFORMAATION

\section{ASEELLISTAMINEN JA} TAISTELU IDENTITEETISTÄ

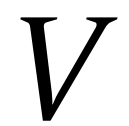

iestintä verkkoympäristössä on yhä useamman viestinnän ammattilaisen keskeinen tehtävä. Verkkoviestinnän onnistuminen vaatii internetin rihmastomaisuuden ymmärtämistä, ja siihen liittyy uudenlaisia läpinäkyvyyden vaatimuksia. Informaatioteknologian sovellutusten eksponentiaalinen kehitys korostaa audiovisuaalisuuden merkitystä.

Rihmastoympäristössä visuaalisella ja auditiivisella viestinnällä on vahvempi sija; propaganda ja tässä artikkelissa käsitelty ns. "agitproppaus" ovat aina perustuneet kuvitettuihin viesteihin, koska tunneulottuvuus saadaan helpommin lisättyä kuvaan kuin tekstiin. Rihmastoituminen sekoittaa rationaa- 
lisen ja tunnepitoisen viestinnän, ja sen sovelluksia on esimerkiksi monelle tuttu sissimarkkinointi. Rihmastoajattelu ei kuitenkaan vielä ole lyönyt lävitse länsimaiden viestintämaailmassa, kun yhteiskunnassamme on vielä vahva illuusio asioiden pysyvyydestä. Verkkoympäristössä vaikuttaminen on yhä enemmän informaatiosotaa ja taistelua yksilöiden identiteeteistä. Huhuista ja juoruista tulee tosiasioita, kun niitä toistetaan tarpeeksi. Artikkeli linjaa, että propagandan kanssa on opittava elämään, sillä läpinäkyvyys rihmastoissa voi hyvin tarkoittaa myös vääristynyttä tietoa.

\section{Raivovapaata tietoa ei ole}

Viimeisen 25 vuoden ajan erityisesti 30ja 40-vuotiaiden läntisten koulutettujen ihmisten suhde internetin ja sittemmin sosiaalisen median maailmoihin on ollut positiivinen usko niiden vapautta, tasa-arvoa ja oikeudenmukaisuutta luovaan todellisuuteen. Erityisesti sosiaalinen media on koettu "vapaan" itseilmaisun alustaksi. Kylmän sodan aikaisen informaatioilmaston aika oletettiin taakse jääneeksi. Toki digitaaliteknologian luoma informaatiomaailma tätä onkin.

Kuitenkin viime vuosien aikana on yhä enemmän voitu todeta, kuinka taakse jääneeksi kuviteltu propaganda, vihanpito, henkinen kiusaaminen ja agitproppaus ovat levinneet vahvasti niin tavallisten nettikuluttajien kuin informaatio- ja media-ammattilaistenkin käyttämään sanastoon ja mielikuviin. Viestinnän alan ammattilainen ei enää raportoi ja katso sivusta tapahtumien kulkua, vaan hän on itse osa tapahtumaa ja sen merkitysrihmastoa. Viesti voi räjähtää käsiin ja jopa tappaa, kuten Charlie Hebdo -iskussa. Uutisen laatiminen poliittisesti ikävästä asiasta saattaa myös johtaa siihen, että toimittajan sosiaalinen media ja sähköposti alkavat täyttyä psykologisen painostuksen, kiusaamisen ja häirinnän tunnusmerkit täyttävistä lokaviesteistä. Digitaalinen vallankumous on myös väkivallan ja vihanpidon vallankumous.

Viimeistään vuosi 2014 laukaisi sosiaalisen median käytön sotilaallisten, poliittisten ja taloudellisten kriisien yhteydessä. Arabikevät ja Ukrainan kriisi ovat nostaneet muun muassa Twitterin ja Facebookin keskeisiksi propaganda- ja trollauskanaviksi. Halusimme uskoa, että ilmaisunvapauden valoa on tunnelin päässä, kun kylmä sota päättyi ja Berliinin muuri murtui. Nyt tuo valo näyttää tulevan vastaantulevan junan lampuista, kuten Zizek (2002) asian ilmaisee. Kestävä kehitys voikin olla kestävää taantumusta, riippuu kummasta päästä toivon ja toivottomuuden lautaa katsomme.

Erityisen pahasti informaation saastuminen ja muuttuminen tappavaksi satuttaa niitä, joille teknologia on merkinnyt uskonnon kaltaista tunnetta paremmasta. Kuten Zizek toteaa, antaa "lapsen" mennä, tarkastelkaamme "pesuvettä". Hän siis tarkoittaa, että meidän on ymmärrettävä verkostoitumisen luonnetta maailmassa, jossa elämme. Tai ehkä meidän on sokaistava itsemme kuten Oidipuksen, jotta näkisimme kaiken kauniin lävitse sen 
todellisen tahman, jossa informaatiouskomme todella lepäilee.

Informaatio alkaa lahota, jos palveluntarjoajat eivät säilytä ja ylläpidä tulevaisuudessa sovellutuksia, joilla vanha algoritmi saadaan avatuksi. Niin sanotun Big Datan seassa voi kymmenen vuoden päästä muhia yhä enemmän informaatiosaastetta ja informaatiolle tuhoisia päättymättömiä rihmastoja, joiden näkeminen nyt ei ole vielä mahdollista. Rinnakkain piilevän tuhon kanssa elää myös piilevä "hyvä". Esimerkiksi satiirilehti Charlie Hebdon tilaajamäärä on 20-kertaistunut tammikuun 2015 terrori-iskun jälkeen. Paradoksaalisesti iskut lehden toimitukseen ovat pelastaneet sen talouden.

Informaatiolla on siis kaksi haastetta pysyäkseen läpinäkyvänä ja hengissä: informaation itsensä laatu teknisessä mielessä sekä sen laatu sisällöllisesti.

\section{Pahimmassa tapauksessa $3 / 4$ informaa-} tiostamme on jollakin tavoin saastunutta: joko teknisesti tai sisällöllisesti tai molempia. Historiallinen kehitys ei ratkea vain ajatuksella pysyvästä globaalista yhteisymmärryksestä. Ihmisten turhautumista ja raivoa ei historian saatossa ole kyetty tukahduttamaan. Informaatio ei ole raivovapaata tietoa. Raivoa ja turhautumista tulee ymmärtää ja antaa niille mahdollisuus olla osa ihmisyyttä ja ihmisyyden ilmentymistä. Vain tätä kautta ne tulevat näkyviksi ja kanavoitaviksi. Voisin jopa väittää, että rihmasto on mahdollisuus, jossa turhautumista ja raivoa ei redusoida pois toiminnan ytimestä. Oleminen rihmastossa tarkoittaa olemista siellä, missä tapahtuu energistä liikehdintää, olipa se sitten väkivaltaista tai rauhanomaista. (Sloterdijk 2009.)

\section{Internet ja läpinäkyvyys}

Kohderyhmien määrittely internetin rihmastojen sopukoissa on ensiarvoisen tärkeää. Perinteinen ajatus esimerkiksi julkisen hallinnon viestinnästä ei enää toimi. Viestimistä oleellisempaa on ensin tunnistaa eri kohderyhmät ja niiden muodostamat viestinnälliset käyttäytymistavat. Samalla tavoin kuin materiaalinen kulttuurien vuorovaikutus lisääntyy, myös virtuaalinen heimoutuminen ja alakulttuurien sekoittuminen on kiihtynyt.

Oleellista on löytää kohderyhmiä, joiden kommunikaatio sisällöstä huolimatta on oman tavoitteen kannalta positiivista ja yrittää vahvistaa omaa sanomaa juuri kohderyhmän käyttäytymisen kautta. Tällaiset luottojoukot antavat omalle viestisisällölle mahdollisuuden pitkäkestoiseen vaikutukseen.

Kohderyhmät, joissa viha ja negatiivisuus leimaavat kommunikointia, vaativat puolestaan syvää ymmärrystä niiden tunnemaailmasta, jotta niiden kautta tapahtuva oman sanoman kommunikointi muuttuisi positiiviseksi. Kieltämällä, torjumalla tai teknisesti eristämällä tällaisista ryhmistä ei päästä eroon. Negatiivisen ilmaisun juuret ovat syvällä rihmastoissa, ja oikeastaan mitä enemmän niitä kitketään, sitä enemmän ne villiintyvät. Haastavin sarka liittyy valheellisiin ja teennäisiin kohderyhmiin, joissa käyttäytymisen perussääntö on identiteettien ja sanoman jälkien peittäminen. Tällainen kohderyhmä vaatii houkuttelua mukaan 
avoimeen keskusteluun. Dynaamisessa rihmastomaailmassa kaikki sidosryhmät voivat sekoittua keskenään ja muuttaa käyttäytymistään positiivisesta negatiiviseen tai valheelliseen sekä päinvastoin ennalta arvaamattomalla tavalla. (Luoma-aho 2015.)

Internetin läpinäkyvyys menetetään, jos heimoutumista ei ymmärretä ja pyritään vain teknisten ratkaisujen kautta kokonaiskontrolliin. Samalla kiihtyy myös informaation saastumisen mahdollisuus.

"Ison Veljen" valvonnan sijasta jokainen nettiä käyttävä ylläpitää jokaisella klikkauksella yhä tihentyvää verkkovalvontaa. "Joku veli" takaa valvonnan onnistumisen (vrt. Mannermaa 2008).

\section{Personoidussa kuplassa?}

Esimerkiksi Facebook ja Google käyvät jatkuvaa kilpailua siitä, kumpi onnistuu sitomaan suuremman osan verkon liikenteestä omiin tietokantoihinsa (Brunila 2014, 76-80). Vaarana on, että lähivuosina internetin suuret palvelut luovat jokaiselle käyttäjälle oman erillisen ja eristetyn informaatiokuplansa. Tämä tarkoittaa sitä, että kaksi eri käyttäjää saa samalla hakusanalla täysin erilaista tietoa, joka rakentuu käyttäjien itsensä luomien käyttöklikkausten historiana. Vuoden 2015 eduskuntavaaleja ja niiden tuloksen yllätyksellisyyttä pidettiin jo tämän kuplan ilmentymänä. Alamme sulkeutua omaan reflektiotietoomme. Omat asenteemme vahvistuvat vahvistumistaan, koska jatkuvat informaatiosyötteet tarjoavat meille jo ennalta haluamaamme tietoa "uutena" informaationa. Kymmenen klikkausta, ja Facebook tuntee informaatiotarpeesi työkavereitasi tarkemmin. Neitseellinen tieto on menetetty.

Vuonna 2009 Google lähti tavoittelemaan tulevaisuutta, jossa personoidut haut tulisivat koskettamaan kaikkia sen käyttäjiä. HTTP-protokolla on "tilaton", mutta persoonallinen informaatiokupla voidaan synnyttää juuri evästeiden, javaskriptien ja IP-osoitteiden avulla. Pahimmassa tapauksessa me itse automatisoimme itsellemme teknisen trollauksen päälle. Esimerkiksi omien kulutustuotteiden ja mieltymysten googlaaminen johtaa siihen, että jokainen hakukerta vahvistaa ja tarkentaa juuri halujemme ylläpitämistä. Vahvaa poliittista kantaa edustavien sivujen ahkera käyttö tekee hakemastamme informaatiosta yhä poliittisesti vahvempaa. Voimme aluksi käydä melko neutraaleilla sivuilla, mutta yhä useampi käyntikerta tuottaa linkkejä, joista pääsemme yhä syvemmälle meille profiloituun informaatioon. Informaation syventyminen voi samalla merkitä sen lisääntyvää saastumista, jota emme osaa huomata. On kuin joku kirjoittaisi meille tarinaa meistä itsestämme. Mitä yksilöllisempää informaatiota haluamme, sitä enemmän meidän on paljastettava itsestämme.

Internet edistää ajan ja tilan sulautumista. Jotta voisimme kokea todellisuuden tilana, tarvitaan ajallista kestoa. Tällä hetkellä netin käyttäjien vaatimus käyttäjäystävällisyydestä ja teknisten toimenpiteiden minimoimisesta kadottaa käyttäjältä kokemuksen verkon fyysisyydestä. Jokainen klikattu halu vaaditaan 
avautumaan välittömästi, eikä kokemusta odotuksen luomasta netin fyysisestä tilasta enää saavuteta. Emme enää ymmärrä, missä klikkaamamme tiedon fyysinen IP-osoite sijaitsee. Olemme instant-tilassa vailla todellista keston ja tilan tuntua. Myös käyttäjien omien tietokoneiden minimaalinen tallennuskapasiteetti ja informaation siirtyminen "pilviin" tekee meistä tiedon suhteen ulkoistettuja. (Kullenberg 2014, 53-54.)

\section{Teknologia ja tuho}

Teknologiaa ei voi olla ilman onnettomuuden mahdollisuutta: esimerkiksi matkapuhelimen keksiminen tarkoitti myös tienvarsipommin laukaisukojeen keksimistä. Virilio näkee onnettomuuden matemaattis-luonnontieteellisen edistyksen negatiivisen lisääntymisen tuotteena. Teknologian leviäminen, varsinkin digitaalisuuden ja virtuaalisuuden kohdalla, erottaa ihmiset todellisen ajan ja avaruuden tapahtumista. Kadotamme intuition ja tuntuman välittömään näköpiiriimme ja turvaudumme teennäiseen. Väkivalta katkeaa mainoskatkoon tai karaokebaarin leppoisa ilmapiiri mustasukkaisen laukauksiin. Tulevia törmäyksiä peittää lempeä maisema. Juuri simulaattoreiden ja tietokonepelien suosio liittyy tähän todellisen ja virtuaalisen tunteen ristivetoon. Simulaattoriteollisuus on myös hyvä esimerkki sodan tuomasta tekniikan kehityksestä: se syntyi toisen maailmansodan jälkeisen tieteen ja aseteollisuuden liitosta. (Virilio 2002 ja 2000.)

Virilion mukaan (1986) nykyaikaisessa sodankäynnissä logistiikka ei viittaa vain henkilöiden, ajoneuvojen, polttoaineen ynnä muiden kuljettamiseen, vaan myös kuvien liikkeeseen taistelukentältä pois ja takaisin. Uutistenmetsästäjä ottaa kuvia, jotka lähetetään valtamedialle, joka voi sitten esittää ne julkisesti. Yhä useammin sosiaalinen media toimii logistiikan keskuksena. Havainnon logistiikka liittyy myös sotilaallisten operaatioiden ja konfliktikuvien televisiointiin, jota ei katsota ainoastaan kotona: myös itse konfliktiin sekaantuneet katsovat sitä. "Taistelukentän" lisäksi on siis olemassa "havainnon kenttä", jolla aikaisemmin salaisestakin tiedosta on tullut julkista.

Myös median ammattilaiset joutuvat nostamaan kätensä ylös näppäimistöltä. Mahdollisuus tutkivaan journalismiin, tietojen tarkistamiseen, ristiin ajamiseen, vaihtoehtoisten näkökulmien luomiseen ja oman jutun kriittiseen arviointiin on menetetty. Medioiden elinehto on instant-nopeus, ja se tarkoittaa väistämättä sisältöjen nousemista syvyyksistä pinnallisiksi. Lisäksi ihmisten käyttötottumuksien muutokset johtavat kehityksen myötä siihen, että tekstistä siirrytään kuvaan. Jo nyt esimerkiksi Twitter tekee tekstin lukemisesta haastavaa erilaisilla hashtageillä.

Tällaisessa ympäristössä kielioppi hyppää tekstistä kuvaan. Seuraavat sukupolvet ovat yhä valmiimpia kuvitettuun maailmaan. Tällä tietysti on ennen pitkään valtaisat vaikutukset ihmisten mielikuviin ja todellisuuden konstituoimiseen. Teknologiatuotanto tietää sen. Nykyaikaiset viestinnän muodot suorastaan yllyttävät puhumaan kuvilla. Kuvakirjoitus ei edellytä luku- eikä kirjoitustaitoa. 


\section{O, / 101}

Se ei myöskään vaadi yhteistä kieltä. Palataan takaisin siihen historialliseen tosiasiaan, että milloin missäkin kulttuurissa kasvaneet ihmiset ovat oppineet käyttämään ihan vieraan kulttuurin emojeja merkitsemässä ihmistä tai työtä tai rahaa. Kun kirjoittamiseen käytetään tietokonetta, ei tarvita piirustustaitoa. Merkkejä vain otetaan valmiista valikoimista. Aikaa syvälliseen tekstitulkintaan ei enää ole. Kuvan suhde propagandaan on läheisempi kuin tekstin. Propaganda ja agitproppaus ovat aina perustuneet kuvitettuihin viesteihin, koska tunneulottuvuus saadaan helpommin lisättyä kuvaan kuin tekstiin. Propaganda on toimintaa, tekoja ja tuotteita, joilla pyritään vaikuttamaan ihmisten asenteisiin, uskomuksiin, mielipiteisiin ja tietoihin. Agitproppaus puolestaan on kontrolliyhteiskunnan pyrkimys valvoa, tarkastaa ja tarvittaessa puuttua yhteiskunnallisen informaation sisältöön.

\section{Taulukko 1}

Läpinäkyvyyden kannalta arveluttavia viestinnän muotoja

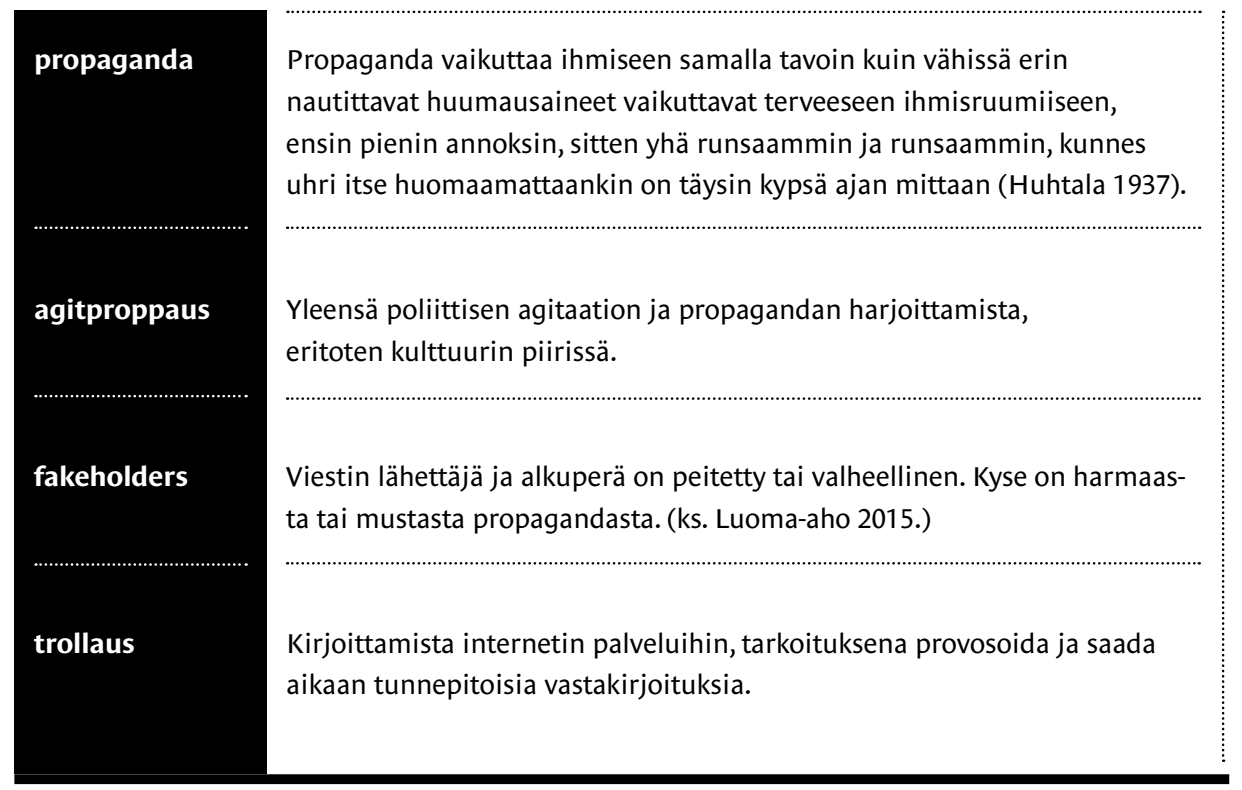


Turvallistaminen ja maalittaminen

Turvallisuus alkoi 1990-luvulla muistuttaa yhä enemmän turvallistamista. Kansallinen turvallisuus rekonstruoitiin kuten kansainvälinen ja globaali talous. Kovaan sotilaalliseen ja perinteiseen ytimeen alkoi virrata liberaalidemokraattisen lännen ajattelussa uusia ilmiöitä, kuten ympäristöongelmat, sukupuolikysymykset, median kasvava rooli, maahanmuutto ja ihmisten liikkuvuus sekä kyberasiat. Samalla yksilön ja yhteisöjen verkostoituneet intressit, halut ja tarpeet nousivat perinteisen valtiokeskeisen turvallisuuden rinnalle. Organisaatioiden ja instituutioiden moniäänisyys, uudet hierarkiat, projektiluontoisuus, raskaan byrokratian purkautuminen ja alati kasvavien ilmiöiden kietoutuminen yhteen sekä takaisinkytkennät tekivät yhä hankalammaksi vallitsevan tilannekuvan hahmottamisen. (Shaw 2000, 13-14.)

Mediabisnes, kuten turvallisuusorganisaatiot, ovat yhä riippuvaisempia informaatiosta. Informaatio ei ole vain neutraali resurssi, vaan siitä on kehittymässä hyvää vauhtia myös oma lainalainen ase. Yhä aggressiivisempi mainonta sekä siihen liittyvä asiakkaiden "maalittaminen" hyödyntää monia toimialoja, mainonnasta turvallisuus- ja tiedusteluorganisaatioihin. Asiakkaiden ja ihmisten sosiaalisista suhteista ja kulutustottumuksista saadaan tutkimalla tietoa niin talouden kuin turvallisuudenkin pyöriin. Talous ja turvallisuus perustuvat yhä integroidummin yhteneviin johtamis- ja organisaatiomalleihin, joita tuetaan logistiikan terävöittämisellä (Munro 2005).
Vastavoimana globalisaation informaatiotsunamille ovat olleet muun muassa ei-kaupalliset ja enemmänkin ideologiset ilmiöt, kuten Napster ja Linux, jotka ovat ottaneet oppia niin sanotuista nomadimaisista organisaatiorakenteista ja pyrkineet rikkomaan globaaleja markkinoiden pelisääntöjä siinä kovinkaan hyvin onnistumatta. Näille "sissibisneksille" läheistä sukua organisoitumisen kannalta organisoitumissukua ovat myös varsinaiset poliittiset liikkeet, kuten Meksikon Zapatista tai Taleban, ja nyt Isis-terroristiorganisaatio. Tahtomattaan läntiset liberaalidemokratian ja teknologiauskon organisaatiot ovat tulleet militarisoiduiksi ja aseistetuiksi politiikan, talouden ja informaation osalta taistelussa sananvapauden, tekijänoikeuksien ja yksilönsuojan puolesta. (Chong 2013, 604.)

\section{Putin ja informaatiosota}

Turvallisuusorganisaatiot ovat globaalien pörssiyritysten tavoin tottuneet nopeaan päätöksentekoon. Demokratialähtöinen länsimainen politiikka sai haukkoa henkeään vuoden 2014 aikana, kun Kremlin hallinto näytti poliittisen päätöksenteon nopeuden ja sotilaallisen voimankäytön yhteyden Krimin niemimaan miehittämisessä. Tutkijoiden analyysejä olisi ollut käytettävissä jo 2010-luvun alussa siitä, kuinka Kremlin hallinto toimi vuoden 2008 aikana Georgian sodassa. Läntinen media ei kuitenkaan vielä silloin tajunnut tapahtumien kulkua tai suuri yleisö ei halunnut sitä "ostaa", ja myytti medioidun tiedon luotettavuudesta säilyi. Hybridisodaksi kutsuttu aikakausi oli alkanut. 
Tällainen sodankäynti sekoittaa rauhan ja sodan toiminnot toisiinsa ja hävittää niiden välisen eron juuri informaatioulottuvuudessa. Kansainvälinen

oikeus ja lainsäädäntö eivät ehdi mukaan, koska sotilaallista voimankäyttöä seuraa massiivinen informaatiopropagandan kampanjointi.

Hybridisodassa koodisto kulkeekin neljän kohdan (DImE) jatkumona:

1) DIPLOMATIA

2) INFORMAATIO

3) sotilaallinen ulottuvuus

4) TALOUS.

Ruohonjuuritasolla toiminta vaikuttaa sotilaalliselta, mutta diplomatian, informaation ja talouden alueella propagoidaan rauhan ja eri argumenttien puolesta. (vrt. Darczewska 2014.)

Presidentti Putinin hallinnolla ei todennäköisesti ole mitään länsimaisen mittakaavan pitkän tähtäimen strategista suunnitelmaa. Vaikuttaa siltä, että vuosi 2014 on tarjonnut tilaisuuden sille, mitä on tapahtunut. ISAF-operaation päättyminen, presidentti Obaman ulkopolitiikan heikkous sekä EU:n taloudelliset ongelmat ovat avanneet ikkunan, josta on työnnetty uusi ajattelu ulos. Kremlin hallinnon takana työskentelee erityisesti filosofis-ideologinen koneisto. Aleksander Dukinin (2012) oivallisesti käyttämät länsimaisen ajattelun postmodernit kriitikot, kuten Nietzsche, Heidegger, Foucault (2007) ja Virilio (1986, 2000, 2002), ovat ahkerassa käytössä siinä informaatiosodassa, jossa lännen liberaali-demokraattiset ongel- mat rypevät. Guantanamo, Fergusonin poliisin toimet, Afganistan sekä kirkon ja tasa-arvon uudet aallot lännessä sopivat konservatiiviseen vasarointiin. Vuoden 2014 alussa Kremlin valtiomedian johtoon valittu Dmitri Kiseljev on oivallisesti keskittänyt muun muassa Russian Today mediakanavat palvelemaan Kremlin politiikkaa. Poliittinen korruptoituneisuus on antanut mahdollisuuden rakentaa "idän" ja "lännen" ideologis-poliittisen filosofian vastakkainasettelun. Oleellista on peittää se, mitä on tapahtunut, ja pitää esillä sitä, miksi jotakin on tapahtunut. "Tosi", "objektiivisuus" ja "faktat" rakennetaan sosiaalisesti "tyhjästä" postmodernien oppien mukaan. Jokaisen lännen ongelman voidaan rakentaa olevan osoitus läntisen ajattelutavan degeneraatiosta. (Pomerantsev ja Weiss 2014.) Länsi on jumissa, koska se ajattelee, että Venäjä ja erityisesti sen johto valehtelee (Schumatsky 2014). Postmodernismin hengessä "valehtelu" on kuitenkin vain yksi diskurssi, ja poliittinen valehtelu on aina osa politiikkaa, ei vain Kremlissä.

Kremlin käyttämä trollaus ei ole uusi ilmiö. Kansainvälisessä diplomatiassa on nähty muun muassa kylmän sodan aikana vastaavanlaista narratiivin rakentamista. Kuuban ohjuskriisi, Sikojenlahti ja Neuvostoliiton sota Afganistanissa olivat osaltaan aikansa trollaustapauksia. Jälleen kerran Venäjä etsii identiteettiään asevoiman avulla, kuten Yhdysvallat ja Nato Neuvostoliiton hajottua. Peruskysymys on edelleen sama: miksi kansalaiset tukevat militarisoituvaa poliittista johtoaan samaan aikaan, kun oman maan taloudella 
menee yhä huonommin? Klassisen propagandan menetelmien mukaan kansalle on tarjottava leipää ja sirkushuveja. Ukraina on alitajuisten halujen toivetynnyri.

Sotilaalliset voitot ulkopolitiikassa antavat illuusion paremmasta tulevaisuudesta. Rakastamme elokuvan kaarta, jossa vaikeudet johtavat lopulta voittoon. Tässä suhteessa fantasia tulevasta lupauksen täyttymyksestä presidentti Putinin valtiollisissa puheissa omalle kansalle on suoraa kopiota lännen vastaavista toimintatavoista. Fantasia tuotetaan median avulla. (Müller 2012, 284.)

Median keskittäminen ei ole uusi ilmiö. Yhdysvalloissa presidentti Bushin käynnistämä terrorismin vastainen sota vuoden 2001 WTC-iskun jälkeen kanavoi Yhdysvaltojen päämediat poliittisen hallinnon ja erityisesti Pentagonin käyttöön (Munshi 2004, 46-60). ABC, NBC, CBS ja erityisesti Fox News pyörittivät 24/7-uutisointia poliittisen agendan puolesta. Sota kehystettiin yhdysvaltalaiselle ja osittain eurooppalaiselle yleisölle ymmärrettävään muotoon. Presidentti Bush esitettiin ratkaisun avaimena, ja hänen määrätietoinen ja sporttinen persoonansa sekä kansaan ja kadunmieheen uppoava julkisuuskuvansa toivat menestystä. Vastaavalla tavalla samaa konseptia sovelletaan nyt Kremlissä. Nopeus, hyökkäävyys, omien oikeuksien puolustaminen, väärän ja vihollisen määrittely ja kärsimyksen kautta voittoon -mantrat uppoavat meihin "tavallisiin" kuluttajiin.

Etäisyys on toiminut keinona määrittää eri ihmisten ja ihmisryhmien identiteettiä. Internetaikana etäisyyden käsite muuttaa muotoaan. Fyysinen etäisyys ei enää toimi jakona "meihin" ja "heihin". Saatamme tuntea myötätuntoa maailman äärissä luonnonkatastrofin pyörteissä olevia tuntemattomia ihmisiä kohtaan ja samaan aikaan paheksua porttikongeissa ja kadunkulmissa olevia jengejä. (Munro ja Huber 2005.) Munro $(2009,199)$ jatkaa, kuinka informaatiosodankäynti on nimenomaan taistelua identiteetistä. Kuka tahansa voi helposti käynnistää muun muassa sosiaalisessa mediassa taistelun käsitteistä ja identiteeteistä. Pyrkimyksenä on vakiinnuttaa omat käsitteet ja niiden määrittelyt eri keskustelufoorumien hyväksymiksi. Kuitenkin edelleen laajojen vaikutusten aikaansaamiseksi tarvitaan valtamedioiden tukea. Esimerkiksi Kreml on kasvattanut "informaatiotaistelun" budjettiaan yli 300 miljoonalla dollarilla, mikä sisältää monikielisen jatkuvan uutisoinnin langattomissa palveluissa ja radiopalveluissa. Saksan- ja ranskankielisten ohjelmien osuus on kasvanut vuoden 2014 aikana 41 prosenttia. Lisäksi sosiaalisen median käyttö eri keskusteluryhmissä on normaalia toimintaa. (Pomerantsev 2014.)

Miksi demokratisoituminen on luiskahtanut eriarvoistumisen kierteeseen? Syynä saattaa olla yhteiskunnan perusteellinen muutos, kun olemme siirtyneet teollisen ajan elämäntavoista digitaaliaikaan. Yksilön valinnanmahdollisuuksien lisääntymisellä on kääntöpuolensa, joka usein unohdetaan: yksilölliset valinnat voivat olla yksilön kannalta huonoja. Päätän olla kouluttautumatta, päätän käyttää päihteitä, päätän jäädä työttömäksi tai päätän opiskella aikuisiällä ovat ehkä 
aitoja valintoja, mutta ne ohjaavat yksilöä yhä kauemmaksi normiyhteiskunnan perusvirroista. Vaihtoehtoisen ajattelun ja elämäntavan takana on aina myös edistyksen siemeniä yksilön näkökulmasta, mutta massayhteiskunta ei välttämättä pidä niitä edistyksellisinä. Vapaus valita on siis yhä enemmän yksilön itsensä harteille jäävää vastuuta valintojen seurauksista. Vihapuhe on signaali joidenkin kansalaisten tarpeesta saada muutosta aikaan, mutta muutos ei välttämättä ole laajasti jaettua ja koettua. Vihalla saa myös niin sanottua kasvoaikaa ja vahvistettua oman identiteetin näkyvyyttä. (Airaksinen 2013.)

Miksi sitten löydämme itsemme tästä uudesta tilanteesta? Tai oikeastaan miksi historia näyttää toistavan itseään vaikkakin uusin muodoin? Valotan tilannetta niin sanotun puu- ja rihmastoajattelun eroilla.

\section{Puu- ja rihmastomalli}

Edellä kuvatun tilanteen taustalla on pitkä kehitys länsimaisessa tietokäsityksessä. Olemme totutettuja ajattelemaan, että asiat "ovat". Kielen tasolla lukitsemme jonkin asiantilan siten, että se lopulta näyttäytyy staattisena ja "olevana". Tyypillisesti länsimaisessa valta-ajattelussa meidät on opetettu ajattelemaan niin sanotun puurakenteen kautta. Asioilla "on" alku ja loppu, ne muodostuvat jonkin periaatteen, syyn tai viimeisen rungon varaan. Sen sijaan ajatus siitä, että kaikki on jatkuvasti "tulossa" ja mitään pysyvää ei ole, on jäänyt enemmänkin taiteen ja runouden varaan. Täällä puun metaforaan vastaa rihmasto. Rihmasto ei ala mistään eikä lopu mihinkään. Rihmasto ei pysähdy, eikä sitä voida säätää ja kontrolloida. Rihmasto voi katketa ja kytkeytyä mistä tahansa. Rihmastoon voidaan tulla sisään useista eri paikoista. Deleuze ja Guttari (1983) kuvaavat tätä rihmastomaista kehitystä syvällisesti. Voimme ajatella viimeisen 25 vuoden informaatioverkkojen läpinäkyvyyden haasteita juuri rihmastoajattelun kautta.

Rihmastot kasvavat ja kytkeytyvät sekä poikittaisessa että pystyssä suunnassa. Vastavuoroisuus, moninaisuus ja hybridimalli kuvaavat hyvin rihmastoa. Rihmasto ei ole niinkään puurakenteen vastakohta kuin jatkuvan väistämisen, vetäytymisen ja pakenemisen kuvaus puurakennetta vastaan. Sosiaalinen sukupuoli, tasa-arvo, seksuaalinen vapaus, eri uskontojen tapakulttuurien sulautuminen, poikkitieteellisyys, uusioperheet, vapaa liikkuvuus, 24/7-informaatiovirtaus ja viruskantojen vahvistuminen ovat rihmastomaisia kuvauksia. Alun ja lopun puuttuminen johtavat siihen, että rihmastoissa kaikki tapahtuu "keskellä". Kuvaus kultakalojen liikkeistä lasimaljassa tai rottalaumojen parveilusta kellareissa kuvastaa rihmastoliikettä. Yhden yksilön suunnanmuutos aiheuttaa mahdollisesti koko muun lauman tai massan äkillisen suunnanmuutoksen. Pinnallisuus, katkokset, suunnittelemattomuus ja satunnaiset kytkeytymiset ovat osa rihmastokäyttäytymistä. Huhuista ja juoruista tulee tosiasioita juuri sillä, että ne monistuvat rihmastoissa tulvien ja peittäen alleen kaiken selväpiirteisen rakenteen. (Deleuze ja Guttari 1983, 10.) Rihmastoon voidaan kytkeytyä mistä 
tahansa, ja rihmasto voi katketa tai murtua mistä tahansa. Yhtä tapaa mitata tai kuvata samanaikaista toimintaa ei ole. Tarvitaan useita eri tapoja saman tapahtuman hahmottamiselle. Minkäänlainen järjestäytynyt vastarinta ei ole rihmastossa mahdollista. Rihmastossa ei ole keskitettyä johtoa eikä päätöksentekoa. (Deleuze ja Guttari 1983,15.) Rihmasto on liian hajautunut johdettavaksi hallinnoimalla. Esimerkiksi globaalit energiamarkkinat, mainostaminen ja rahavirrat eivät ole vapaita poliittisen ohjauksen verkostoista.

\section{Biopolitiikka: metaforin vaikuttaminen}

Kulttuurin, informaation ja talouden "aseellistaminen" (weaponization) (Munro 2005) on seurausta rihmastomaisuuden luonteesta. Käyttäjäystävällisen verkon pinnan alla rihmastoissa tapahtuu "kytkentöjä", jotka eivät ole pelkästään positiivisia. Virilio $(1986,2000,2002)$ ja Zizek (2002) ovat kuvanneet tuotannossaan laajasti niitä seurauksia, joita globalisaation ja informaatioyhteiskunnan rihmastomaisuus tuo tullessaan. Kaiken toiminnan kiihtyminen johtaa annettujen asiantilojen irtoamiseen puurakenteesta ja niiden hajaantumisen ja laajentumiseen. Michel Foucault (2007) on omissa tutkimuksissaan esitellyt käsitteen "biopolitiikasta", jossa biologian sanastoa hyväksi käyttäen voidaan kuvata poliittisia asiantiloja.

Esimerkiksi terrorismia ja rikollisuutta voidaan verrata ihmisen elimistössä lymyäviin viruksiin, joita vastaan kehitetään täsmäaseita. Talouden alalla digitaalisen monistamisen ja kopioinnin mahdollistama kiihtyvä asiantilojen ja tuotteiden laajentuminen johtaa tilanteeseen, jossa kopioiden hinta putoaa lähelle nollaa ja niiden kysyntä lähestyy ääretöntä. Tällaisessa tilanteessa rihmasto toimii optimaalisesti, eivätkä puumaiset normit, säädökset ja rajoitteet enää toimi. Rihmastomaisuus siis ensi kädessä haastaa sovitut ja vallitsevat toimintatavat, normit ja arvokäsitykset.

Teknologia siis hajauttaa sosiaalisia suhteitamme, mutta samanaikaisesti uudet rihmat johtavat mahdollisuuteen pysäyttää jokin ilmiö puurakenteen muotoon, erityisesti kun ihmisyhteisö tarvitsee kriisissä tai katastrofissa erityistä suojaa, turvallisuutta tai valvontaa. Datavirtojen kiihdyttäminen kiihdyttää myös datan kasaantumista muutamalle suuryritykselle. Kryptoavaruuden eli salattujen ja suojattujen reittien käyttö on selvästi hitaampaa kuin niin sanotun vapaan kyberavaruuden käyttö. Protestiliikkeet, kuten 15M, ovat esimerkki siitä, kuinka sosiaalisen median avulla, esimerkiksi koordinoidulla hashtagien käytöllä Twitterissä, pidetään yllä maksimaalista reaktionopeutta. Tähän lisättynä populismi, eli kansan ja eliitin vastakkainasettelu, synnyttää nopeasti leviävän liikehdinnän.

Usein muutos huomataan liian myöhään, koska tapahtumat pyritään älyllistämään tai tunneperäistämään puun rungon perusmerkityksiin. Muutos hiipii sisään pienten asioiden kautta, ja jossain vaiheessa hätkähdetään siihen, että muutos on tapahtunut. Muutosta on myös yritetty hallita ajamalla sitä läpi määrätietoisesti ja suurilla resursseilla. Usein muutos on kuitenkin jatkuvan tulemisen tilassa 
ja se tapahtuu kuin eroosio: hitaasti ja huomaamatta. Näin on käynyt internetille ja erityisesti sosiaaliselle medialle. Ne ovat kuin ladattuja aseita leppoisan mukavissa puitteissa.

Brunilan (2014, 117-118) mukaan Twitterille, Facebookille ja Googlelle on se ja sama, millaista tietoa klikkailemme, kunhan kaivamme sitä niiden kautta. Samalla kun käytämme sosiaalista mediaa, se käyttää meitä. Kun nuori rikkoo esimerkiksi koulun kurivaltaa käyttämällä älypuhelintaan tunnilla, samalla hän kytkeytyy toiseen vallankäyttöalustaan. Vallasta ei koskaan pääse eroon. Alistumme uuden vallan palvelukseen juuri siksi, että näemme niin paljon toivoa ja vaivaa

\section{Taulukko 1.}

Puu- ja rihmastomallin erot sinne päästäksemme. Vallanpitäjät saavat kuitenkin aina haluamansa ja maksavat siitä ilosta vähemmän kuin sinne pyrkivät. Ihmiset jäävät esimerkiksi Facebookiin, koska ovat uhranneet niin paljon profiiliensa eteen ja ns. vaihtamiskustannukset ovat korkeat. Siirtyminen uusiin palveluihin on aina työlästä.

Voidaankin erottaa kaksi eri yhteiskuntamuotoa:

1) Traditionaalinen, keskitetty vertikaalinen puumainen rakenne, jossa metsä peittyy puiden alla

2) Virtuaalinen, hajautettu rihmastomainen (rhizome) rakenne, jossa metsä näkyy puista huolimatta

\section{Puumalli}

Rihmastomalli

Mitään perimmäistä ideaa tai syytä ei ole, eikä yleiskäsitteitä tai metalähtökohtia esiinny, kaikki on koko ajan "tulossa".

Vahvistaa jatkuvan tulemisen ja muuttumisen muotoja, kaikki on suhteellista ja kaikki on kytköksessä kaikkeen. 


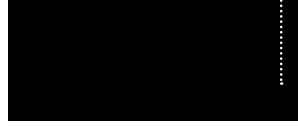

\section{Missä esiintyy?}

Matemaattis-luonnontieteellinen

ajattelu, patriarkaalisuus, muoto-keskeisyys.

Epävirallisissa organisaatioissa, innovaatioissa, marginaaleissa, sisällöissä.

Miten arvioidaan
muutosta?

Mitataan kellonaikaa, geometria ja algebra, lineaarisuus, staattisuus, nopeus, pysähdys.

Eläydytään, ajaudutaan, jäädään odottamaan, kiihtyvyys ja hidastuminen

\section{Oletus?}

Ylläpidetään vanhoja rakenteita ja rakennetaan kokonaan uusia.

Monistetaan, kopioidaan, muutetaan toimintatapoja ja käyttötarkoituksia, ei eroa uudessa ja vanhassa.

\section{Metsä ei näy puilta}

Rihmastoajattelu ei ole lyönyt lävitse länsimaiden valta-ajattelussa, koska puurakenne luo illuusion asioiden pysyvyydestä ja oikeasta järjestyksestä. Kuitenkin postmoderni aika ja globaali informaatiokulttuuri muuttavat suhdettamme todellisuuden jäsentämiseen. Haasteena rihmastomallissa on se, että meillä ei juurikaan ole kokemusta isojen ihmisyhteisöjen sosiaalisesta toiminnasta rihmastoalustalla. Rihmasto- ja nomadimaisuus on ajan saatossa nopeasti kategorisoitu suhteessa valta-ajattelun puumalliin, ja rihmastomaisuus on nähty rikollisuuden, laittomuuden ja marginaalisuuden organisoitumistapana.

Rihmastomaisuuden yksi perusperiaate on muuttaa vallitsevan toiminnan pelisääntöjä ja tapoja. Rihmastomaisuus ei pyri syrjäyttämään vallitsevaa puumaista valtajärjestelmää, vaan osoittamaan, että valtajärjestelmän toimintaperiaatteet, lait ja säädökset eivät ole absoluuttisia, vaan ne ovat ihmisen luomia puutteellisia ja vajavaisia kokonaisuuksia. Rihmastomaisuuden hyväksyminen osaksi jokapäiväistä toimintaa avaisi jatkuvan mahdollisuuden nähdä "metsä puilta". Näin tuskin tulee tapahtumaan, koska se tarkoittaisi niin yksilö- kuin yhteisötasolla mullistavia asenne- ja arvomuutoksia toiminta- ja elämäntapoihin.

Ihmisten välinen vuorovaikutus on yhä enemmän muutaman suuren palvelutarjoajan käsissä. On aivan sama, oletko kansalainen vai viranomainen: ideologinen vastakkainasettelu on mennyttä. 
Epäarvoistuminen on epäarvoistumista suhteessa palveluntarjoajaan, ei poliittisiin ideologioihin. Olet sitten kansalainen, viranomainen tai toimittaja, joku on jo päättänyt, millaisilla ohjelmilla työtäsi teet. Itse et sitä enää päätä. Kaikkia kannustetaan olematta arkistoimatta dataa omalle henkilökohtaiselle tietokoneelle ja luottamaan "pilveen". Lopulta menetetään myös henkilökohtainen kamera, lukulaite ja nauhuri. Kaikki on verkossa ja alttiina verkkojen häiriöille. Uudet ja loputtomat syötteet tekevät eilisen tuskalla luodusta jutusta katoavaa historiaa. Isisin rikokset mediakroonistuvat, ja Krimin miehitys alkaa tuntua normaalilta. Uudet syötteet ja mainokset helpottavat ja suuntaavat ajattelun pois ikävistä asioista. Yksi sisäänkirjautuminen, ja sinut ympäröi sinua profiloiva tieto.

Rihmastomaisuus informaation perusominaisuutena näkyy hyvin niin sanotussa Big Datassa. Dataa kerätään ilman suunnitelmaa, ja tarkkaan ei tiedetä, mihin sitä käytetään. Se on oiva alusta myös kybertaistelulle tai hybridisodalle. Taistelusta, sodasta ja väkivallasta tulee yhä subjektiivisempi, suhteellisempi ja epämääräisempi käsite. Esimerkiksi sotia ei enää julisteta, vaan niihin liu'utaan. Käytetään näkyvää voimaa vasta, kun kriisi on tarpeeksi pitkällä. Aggression valmistelu alkaa paljon aiemmin, ehkä vuosia aikaisemmin. Eikä sen tarvitse olla tietoista. Toiminta pyritään pitämään sellaisella tasolla, että potentiaaliset kohteet eivät uskalla reagoida liian vahvasti.

Esimerkiksi hybridimäisestä informaatiovaikuttamisesta sopii Venäjän
Ukrainaan lähettämän niin kutsutun humanitaarisen avun kuorma-autosaattue. Venäjältä Ukrainaa lähestyviä rekkajonoja seurattiin länsimaissakin suurella mielenkiinnolla, ja niiden reittiä, päämäärää ja sisältöä pohdiskeltiin niin valta- kuin sosiaalisessa mediassakin. Jossain jopa haluttiin ylläpitää epävarmuutta tarkoituksellisesti, koska se antaa sekä poliittista että taloudellista etua. Ihmiset lopulta siedättyvät epävarmuuteen, ja siitä tulee normaali olotila.

\section{Epänormaali on normaalia}

Viestinnän ammattilaisten yhdeksi tehtäväksi tulee rihmastoajattelun ymmärtäminen ja sen vaikutusten läpinäkyväksi tekeminen. Voidaankin linjata kolme ajatusta läpinäkyvyydestä:

1) Informaatioverkostoja ei voida kontrolloida ja mallintaa stabiililla puurakenteella.

2) Propagandan kanssa on opittava elämään, sitä ei voida enää kitkeä pois.

3) Esitetty läpinäkyvyys voikin tarjota myös vääristynyttä ja valheellista tietoa.

Nurhamin (2014) mukaan erityisesti poliittiset päättäjät ja virkamieskoneisto ovat yhä kasvavan informaatiomäärän vankeja. Lisäksi tuki- ja sihteeripalveluiden siirtyminen jokaisen työntekijän itsensä vastuulle johtaa tilanteeseen, jossa yhteiskunnallisten asioiden valmistelutyö muuttuu yhä pinnallisemmaksi ja alkaa muistuttaa maailman medioitumisen luonnetta. Yksinkertaisesti millään elämänalueilla 
ei ole aikaa perehtyä asioiden oikeaan tilaan riittävän tarkasti. Luotamme yhä enemmän siihen, että informaation nopeus auttaa korjaamaan tiedon riittämättömyyttä. Olemme luovuttamassa rihmaston tihentymisen edessä, ja ennen pitkää olemme pakotettuja luopumaan puumallin lähtökohdasta. Julkisiin palveluihin kohdistuvat palvelunestohyökkäykset lisääntyvät, ja esimerkiksi pankkien ja sosiaaliturvaorganisaatioiden palvelutarjonta tulee jatkossa yhä enemmän epävakautumaan. Ihmiset ovat tottuneet asioimaan verkoissa nopeasti ja reaaliaikaisesti. Tämän käyttötottumuksen häiritseminen ja vaikeuttaminen ei ole vain kiusantekoa vaan jatkuvasti kasvava taloudellinen bisnes. Joudumme maksamaan yhä kovemman hinnan yhä halpenevasta teknologiasta. Tässä on juuri rihmastoitumisen paradoksi.

Valtamedian on opittava elämään siinä kehityksessä, jossa se on kykenemätön välittämään esimerkiksi Itä-Ukrainasta riippumattoman ja tasapuolisen journalismin ihanteiden mukaisia uutisia. Tähän vaikuttaa ennen kaikkea resurssipula rihmastorakenteissa: paikan päälle ja joka kriisiin ei riitä omia toimittajia, eikä toimituksissa ole aikaa eikä ammattitaitoa uutisaineiston kriittiseen arviointiin. Tällöin informaation rihmastoissa usein toistettua väitettä sekoitetaan tahattomasti vahvistettuun väitteeseen. Havaintoa ja siitä tehtyä päätelmää ei lopulta voida erottaa toisistaan. Joudutaan tukeutumaan asiantuntijoihin varmistamatta, että heillä on asiantuntemusta siitä asiasta, josta he puhuvat. Informaatiosodan ydin on kyseenalaistamisessa. Eri kertomusten tueksi löytyy selkeitä viitteitä, mutta myös niitä vastaan löytyy riittävästi vastainformaatiota, jotta kummankin osapuolen kertomuksia voi järjellisesti ja rehellisesti epäillä. Lopulta kukaan ei ole rihmastoissa syyllinen.

Tällä hetkellä on vielä liian aikaista sanoa, millaiset seuraukset rihmastoitumisella ja globalisoituvalla mikromanageroinnilla on identiteettiimme ja laajoihin sosiaalisiin suhteisiimme. Selvää on, että internetiä ei voida pysäyttää ja olemme kietoutuneet sen syövereihin koko arjessamme. Informaatiosaasta ja trollaus ovat ilmiöitä, jotka kulkevat käsi kädessä kaiken hyvän kanssa. Kirjaimet muuttuvat aidoiksi kuvamerkeiksi (emojit). Informaatioavaruus saastuu, kuten klassinen luontokin. Propagandan seassa on vain opittava hengittämään.

Miten me kaikki selviämme rihmastoissa? Lukemalla laajasti ja kriittisesti. Ei ole mitään eroa, lukeeko tieteellistä tekstiä vai sarjakuvia. Kaikki, mikä lisää ajattelua, on käyttökelpoista. Tekstin auktoriteetteja ei ole. Tekstillä tai kuvalla ei ole merkitystä ilman jatkuvaa merkitsijää. Järkevä lause saattaa olla merkitykseltään arvoton hyvän lausahduksen tai sanattoman viestin edessä. Pitää muistaa, mitä on lukenut ja missä rihmaston kohdassa. Kaikki uusi luettu on tarkastettava, ja asiantuntijoita on epäiltävä. Kukaan ei sellaisenaan ole hyvä tai paha eikä varsinkaan neutraali. Vaikeneminen on vahva viesti, ja oleellinen on kuvattuna aina kuvan ulkopuolella. 


\section{Lähteet}

Ahlroth, J. (2014). Trolli ärsyttää tahallaan ja muuttaa keskustelun suuntaa. Helsingin Sanomat. 18.11.2014.

Airaksinen, T. (2013). Yksilöturvallisuutta etsimässä. Suomen pelastusalan keskusliitto.

Brunila, M. (2014). Runsauden räjähdys internet hakutalouden jälkeen. Brunila, M. \& Kallio, K. (Toim.): Suljettu verkko. Internet ja avoimuuden rajat, 69-134. Helsinki: Into.

Chong, A. (2013). Information Warfare? The Case for an Asian Perspective on Information Operations. Armed Forces \& Society 2014, 40(4) 599-624.

Darczewska, J. (2014). The Anatomy of Russian Information Warfare. The Crimean Operation. A Case Study. Centre for Eastern Study. Saatavilla verkossa: http:// www.slideshare.net/tblogosphere/the-anatomy-of-russian-informationwarfare.

Deleuze, G. \& Guattari, F. (1994). Nomadology: The War Machine. Kääntänyt Brian Massumi, Oakland, CA: AK Press.

Deleuze, G. \& Guattari, F. (1983). On the line. New York: Semiotext(e).

Dugin, A. (2012). Fourth Political Theory. UK: Arktos Media.

Foucault, M. (2007). Security, Territory, Population. Lectures as the Collège de France 1977-78. London: Palgrave Macmillan.
Huhtala, O. (1937). Propaganda, aikamme uusi sodankäyntiväline. Otava.

Kirchner, K. (1976). Krankheit rettet: psychologische Kriegführung. Erlangen: Verlag D + C (Verlag für Zeitgeschichtliche Dokumente und Curiosa).

Kullenberg, C. (2014). Verkon tunnelit ja niiden kaivajat. Brunila, M. \& Kallio, K. (Toim.): Suljettu verkko. Internet ja avoimuuden rajat, 43-67. Helsinki: Into.

Luoma-aho, V. (2015). Understanding Stakeholder Engagement: Faith-holders, Hateholders \& Fakeholders. Research Journal of the Institute for Public Relations 2(1).

Lindbohm, K. (1982). Vallankaappaushuhut ja SDP:n propaganda keväällä 1948. Pro gradu -työ. Poliittinen historia. Helsingin yliopisto.

Malgin, A. (2015). Kremlin Troll Army Shows Russia Isn't Charlie Hebdo. The Moscow Time. http://www.themoscowtimes.com/opinion/article/russia-is-not-charlie/514369.html.

Mannermaa, M. (2008). Jokuveli - Elämä ja vaikuttaminen ubiikkiyhteiskunnassa. SanomaPro.

Munro, I. (2005). Information Warfare in Business: Strategies of Control and Resistance in the Network Society. London: Routledge. 


\section{O, / 112}

Munshi, S. (2004). Television in the United States from 9/11 and the US's continuing 'War on Terror'. Single theme, multiple media lenses. Van der Veer, P. \& Munshi, S. (Toim.): Media, War and Terrorism. Responses from the Middle East and Asia, 46-60. London: Routledge,.

Nurhan, A. (2014). Strategic Studies in Developing Countries. Ambassador ( $r$ ) Former Acting Chairman of the Center for Strategic Studies of the Ministry of Foreign Affairs of Turkey (artikkelia ei julkaistu, teksti tekijän hallussa).

Pomerantsev, P. \& Weiss, M. (2014). The Menace of Unreality: How the Kremlin Weaponizes Information, Culture and Money. The Institute of Modern Russia, Inc. 2014. Saatavilla verkossa: http:// www.interpretermag.com/wp-content/ uploads/2014/11/The_Menace_of_Unreality_Final.pdf

Shaw, M. (2000) The Development of "Common-Risk" Society: A Theoretical Overview. Kuhlmann, J. \& Callaghan, J. (Toim.): Military and Society in 21st Century Europe, 13-26. A Comparative Analysis. London: Transaction Publishers.

Sloterdijk, P. (2009). Terror from the Air. Kääntänyt Amy Patton. Los Angeles, CA: Semiotext(e).

Schumatsky, B. (2014). RUSSIA IS A LIE. Putin and the postmodern. Luettavissa http://schumatsky.de/Russia-is-a-lie.htm.
Virilio, P. (1986). Speed and Politics: An Essay on Dromology. New York: Semiotext(e).

Virilio, P. (2000). The Information Bomb. London: Verso.

Virilio, P. (2002). Desert Screen: War at the Speed of Light. London: Athlone.

Virilio, P \& Lotringer, S. (1983). Pure War. Kääntänyt Mark Polizotti. New York: Semiotext(e).

Žižek, S. (2002). Welcome to the Desert of the Real: Five Essays on 11th September and Related Dates. London: Verso. 


\section{Miltä painosi jälki näyttää?}
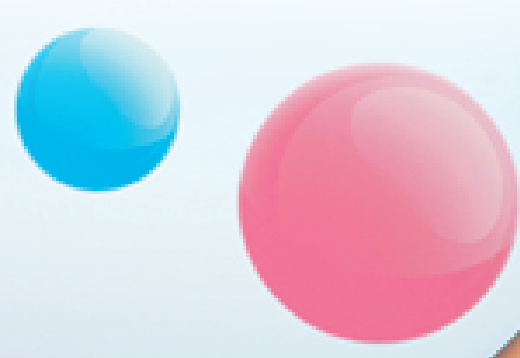

\section{Toivottavasti hyvältä!}

Me Libriksessä olemme aina panostaneet laatuun ja palveluun, painojälkeen ja kädenjälkeen. Libris on tänään edelleen tinkimättömän painojäljen osaaja, vahva markkinointiviestinnän ratkaisujen toimittaja sekä nopea digipaino. Tätä kaikkea voimme tarjota sinulle erittäin kilpailukykyiseen hintaan.

Kun jäljellä on väliä, ja haluat laatua ja palvelua pääkaupunkiseudulla, niin otathan yhteyttä. Myynnissämme sinua palvelevat Jorma Nylander, Juhani Hammarén, Mika Matikka, Harri Nikulainen, Petri Rantanen, Janne Tanner ja Mikko Ilomäki (etunimi.sukunimi@libris.fi). 


ProComma Academic edistää viestintäalan keskustelukulttuuria yhteiskunnassamme. Julkaisu on viestinnän ammattilaisten yhdistyksen ProCom ry:n kustantama ja se pohjaa 1950-luvulla aloitettuun perinteeseen levittää ajankohtaista viestintäalan tietoa. Academic-liite tarkoittaa sitä, että tieto perustuu tutkimuksiin.

ProComma kerää yhteen tutkimuksia ja teoriaa nykyorganisaatioiden dynaamisesta toimintaympäristöstä. Kirjoittajiksi kutsutaan asiantuntijoita eri yliopistoista, mutta myös akateemisen maailman ulkopuolelta.

Vuosittain ilmestyvällä ProCommalla on teema. Tässä ProCommassa pureudutaan läpinäkyvän viestinnän sisältöön eri kulmista. 